\title{
Disentangling cause and consequence: Genetic dissection of the DANGEROUS MIX2 risk locus, and activation of the DM2h NLR in autoimmunity
}

Jana Ordon ${ }^{17}$, Patrick Martin ${ }^{1}$, Jessica Lee Erickson ${ }^{1}$, Filiz Ferik ${ }^{1 f}$, Gerd Balcke $^{2}$, Ulla Bonas ${ }^{1}$, Johannes Stuttmann ${ }^{1^{*}}$

1 - Institute for Biology, Department of Plant Genetics, Martin Luther University Halle-Wittenberg, Weinbergweg 10, 06120 Halle (Saale), Germany

2 - Department of Cell and Metabolic Biology, Leibniz Institute of Plant Biochemistry, Weinberg 3, 06120 Halle (Saale), Germany

${ }^{¥}$ Present address: Department of Plant Microbe Interactions, Max Planck Institute for Plant Breeding Research, Carl-von-Linné-Weg 10, 50829 Köln, Germany

${ }^{\mathrm{f}}$ Present address: Department of Bioengineering, Ege University, Bornova, 35040 Izmir, Turkey

* Corresponding author: Johannes Stuttmann, Martin Luther University of Halle (Saale), Weinbergweg 10, 06120 Halle, Germany, phone +49-345-5526345, fax +49-345-5527151, email, ORCID ID orcid.org/0000-0002-6207-094X

Jana Ordon

Patrick Martin

Jessica Lee Erickson

Filiz Ferik

Ulla Bonas

Gerd Balcke

Johannes Stuttmann

\author{
ordon@mpipz.mpg.de \\ patrick.martin@genetik.uni-halle.de \\ jessica.erickson2525@gmail.com \\ filizferik@gmail.com \\ ulla.bonas@genetik.uni-halle.de \\ gbalcke@ipb-halle.de \\ johannes.stuttmann@genetik.uni-halle.de
}

Running title: Activation of a risk NLR in autoimmunity

Key Words: Plant innate immunity, autoimmunity, hybrid necrosis, EDS1, NLR receptor, TIR domain, SRF3, OASTL-A1, OLD3, CRISPR/Cas

\section{Acknowledgements}

This work was funded by GRC grant STU 642-1/1 (Deutsche Forschungsgemeinschaft, DFG) and seed funding by the CRC 648 (DFG) to JS. UB is grateful for financial support by the Leibniz price from the DFG and the Alfried Krupp von Bohlen und Halbach Stiftung. FF was financed by an ERASMUS mobility program. We are grateful to Bianca Rosinsky for taking care of plant growth facilities and growing plants, and to Ruben Alcazar and Jane Parker for providing plasmids containing SRF3 ${ }^{\text {Kond }}$ or RPP1-like $R 8 / D M 2 h$ genomic DNA fragments. Jan Kemna is acknowledged for cloning of the DM2h cDNA, and Samuel Grimm for primary screening of DM2h-YFP Arabidopsis transformants. 
bioRxiv preprint doi: https://doi.org/10.1101/2020.11.01.363895; this version posted November 2, 2020. The copyright holder for this preprint (which was not certified by peer review) is the author/funder, who has granted bioRxiv a license to display the preprint in perpetuity. It is made available under aCC-BY-ND 4.0 International license.

\begin{abstract}
(225 words)
Nucleotide-binding domain-leucine-rich repeat-type immune receptors (NLRs) protect plants against pathogenic microbes through intracellular detection of effector proteins. However, this comes at a cost, as NLRs can also induce detrimental autoimmunity in genetic interactions with foreign alleles. This may occur when independently evolved genomes are combined in inter- or intraspecific crosses, or when foreign alleles are introduced by mutagenesis or transgenesis. Most autoimmunity-inducing NLRs are encoded within highly variable NLR gene clusters with no known immune functions, which were termed autoimmune risk loci. Whether risk NLRs differ from sensor NLRs operating in natural pathogen resistance and how risk NLRs are activated in autoimmunity is unknown. Here, we analyzed the DANGEROUS MIX2 risk locus, a major autoimmunity hotspot in Arabidopsis thaliana. By gene editing and heterologous expression, we show that a single gene, $D M 2 h$, is necessary and sufficient for autoimmune induction in three independent cases of autoimmunity in accession Landsberg erecta. We focus on autoimmunity provoked by an EDS1-YFP ${ }^{\text {NLS }}$ fusion protein to functionally characterize $\mathrm{DM} 2 \mathrm{~h}$ and determine features of EDS1-YFP ${ }^{\mathrm{NLS}}$ activating the immune receptor. Our data suggest that risk NLRs function reminiscent of sensor NLRs, while autoimmunity-inducing properties of EDS1-YFP NLS are in this context unrelated to the protein's functions as immune regulator. We propose that autoimmunity may, at least in some cases, be caused by spurious, stochastic interactions of foreign alleles with co-incidentally matching risk NLRs.
\end{abstract}

\title{
Introduction
}

Plants growing in natural habitats, as well as crops cultivated in the field, are constantly exposed to pathogenic microbes, which can induce severe damage and yield losses. However, plants evolved two major types of immune receptors to protect from disease (Jones and Dangl, 2006; Dodds and Rathjen, 2010). Extracellularly, membrane-anchored pattern recognition receptors (PRRs) can detect microbeassociated molecular patterns (MAMPs), which induces a suite of responses collectively termed pattern-triggered immunity (PTI; e.g. reviewed in Saijo et al., 2018). Intracellularly, immune receptors belonging to the nucleotide-binding domain-leucine-rich repeat (NLR) class can detect microbial proteins secreted into host cells during the infection process, termed effector proteins, thus inducing effector-triggered immunity (ETI; e.g. reviewed in Cui et al., 2015). Although ETI and MTI are qualitatively similar, they differ in amplitude, and especially ETI is often accompanied by localized cell death at infection sites - the hypersensitive response (HR). So far, ETI and PTI have largely been considered as independent signaling networks, however, recent reports suggest that plant resistance depends on mutual amplification of PTI and ETI responses (Ngou et al., 2020; Yuan et al., 2020).

Plant NLRs are modular proteins consisting of three domains: A C-terminal leucine-rich repeat (LRR) domain, a central nucleotide-binding (NB-ARC) domain and either a coiled coil (CC) or a Toll/interleukin-1 receptor (TIR) domain at the N-terminus (Bentham et al., 2017; Song et al., 2020). These $\mathrm{N}$-terminal domains initiate immune signaling upon receptor activation, and subdivide plant NLRs into TNLs (TIR domain), CNLs (CC domain) and RNLs, which hold an atypical CC domain with homology to the non-NLR resistance protein RESISTANCE TO POWDERY MILDEW8 (RPW8; Meyers et al., 2003; Collier et al., 2011; Jubic et al., 2019). Structurally similar immune receptors, albeit differing in their $\mathrm{N}$-terminal domains, function in animals and fungi. Activation and signaling by animal NLRs 
bioRxiv preprint doi: https://doi.org/10.1101/2020.11.01.363895; this version posted November 2, 2020. The copyright holder for this preprint (which was not certified by peer review) is the author/funder, who has granted bioRxiv a license to display the preprint in perpetuity. It is made available under aCC-BY-ND 4.0 International license.

involves oligomerization and interactor recruitment by oligomeric $\mathrm{N}$-terminal assemblies (Bentham et al., 2017). Recent structural elucidation of a full length plant CNL (HOPZ-ACTIVATED RESISTANCE1 (ZAR1); Wang et al., 2019a; Wang et al., 2019b) and TNL (Recognition of XopQ1 (Roq1); Martin et al., 2020b) revealed assembly of pentameric and tetrameric resistosomes by the activated immune receptors, respectively. Resistosome formation is driven by indirect (ZAR1) or direct (Roq1) pathogen effector recognition, nucleotide exchange (ADP/ATP) within the nucleotide-binding domain and profound conformational changes. In the ZAR1 resistosome, the N-terminal CC domains assemble into a funnel-like structure, which was proposed to translocate into membranes. Thereby, the ZAR1 resistosome might induce the HR directly by interfering with membrane integrity or by functioning as a selective ion channel (Wang et al., 2019a). In the resistosome formed by activated Roq1, two dimers of TIR domain dimers exhibit a two-fold symmetry. This conformation leads to opening of the NADase active site of the TIR domain and breakdown of $\mathrm{NAD}^{+}$(Horsefield et al., 2019; Wan et al., 2019; Duxbury et al., 2020; Martin et al., 2020b). In the latter case, it is assumed that one of the breakdown products of the TIR domain enzymatic activity, whose molecular identity remains to be determined, functions as a signaling molecule. In agreement with an indirect mode of action, resistance mediated by TNLS further requires proteins of the ENHANCED DISEASE SUSCEPTIBILITY1 (EDS1) family and RNL-type helper NLRs of the $\mathrm{N}$ requirement gene1 (NRG1) and/or the ACTIVATED DISEASE RESISTANCE1 (ADR1) class (Wagner et al., 2013; Castel et al., 2018; Wu et al., 2018; Gantner et al., 2019; Lapin et al., 2019; Saile et al., 2020). Nevertheless, it is unknown how a signal is relayed from activated TNLs to RNLs via EDS1 complexes.

Aside from their beneficial function in conferring resistance to invading pathogens, NLRs may become activated erroneously, thus inducing autoimmunity (Bomblies et al., 2007; Chae et al., 2014). Autoimmune plants exhibit hallmarks of innate immune responses, such as marker gene induction and accumulation of the defense hormone salicylic acid. Additionally, plants are commonly dwarfed and exhibit curled leaves, tissue necrosis and spontaneous cell death (Bomblies et al., 2007; Alcazar and Parker, 2011; van Wersch et al., 2016). Autoimmunity has been described in at least three different scenarios: (i) transgenic lines ectopically expressing proteins (e.g. Xu et al., 2014; Stuttmann et al., 2016); (ii) mutant lines obtained in forward genetic screens (e.g. Li et al., 2001; Kim et al., 2010) and (iii) hybrids combining independently evolved alleles, then referred to as hybrid weakness or hybrid incompatibility (HI; Bomblies and Weigel, 2007).

In particular, intraspecific $\mathrm{HI}$ has been well-studied in Arabidopsis (Arabidopsis thaliana). Different degrees of $\mathrm{HI}$, ranging from mild chlorosis to seedling lethality, occurred in approximately $2 \%$ of all hybrids from systematic crossing of accessions representing most of the species' diversity (Bomblies et al., 2007; Chae et al., 2014). Genetic dissection revealed that $\mathrm{HI}$ is generally induced by two genetically separable loci at least one of which encodes an NLR (Alcazar et al., 2009; Chae et al., 2014; Barragan et al., 2019). This pinpoints the plant innate immune system as a key player of HI. NLRs identified as causal in Arabidopsis $\mathrm{HI}$ include, but are not limited to, numerous RECOGNITION OF PERONOSPORA PARASITICA (RPP) loci. RPP loci were identified as conferring race-specific resistance to different isolates of the obligate biotrophic oomycete Hyaloperonospora arabidopsidis (Hpa; formerly Peronospora parasitica). For example, RPP2 alleles present in reference accession Columbia (Col), but not those from accession Landsberg erecta (Ler), confer resistance to Hpa isolate Cala2 (Sinapidou et al., 2004). Similarly, RPP5 from accession Ler, but not genes located at the homologous RPP4/RPP5 locus in Col, confer resistance to Hpa isolate Noco2 (Parker et al., 1997; Noël et al., 1999). In line with the recognition-escape battle ("molecular arms race") dictating natural host-pathogen 
bioRxiv preprint doi: https://doi.org/10.1101/2020.11.01.363895; this version posted November 2, 2020. The copyright holder for this preprint (which was not certified by peer review) is the author/funder, who has granted bioRxiv a license to display the preprint in perpetuity. It is made available under aCC-BY-ND 4.0 International license.

systems, both RPP genes and the corresponding Hpa effectors occur in allelic series and are under strong selection (Botella et al., 1998; Rehmany et al., 2005). While gene clustering is rare in eukaryotes, $R P P$ genes occur in eventually large and diversified clusters undergoing rapid evolution by conjunction of tandem duplications, illegitimate recombination and gene conversions (Jacob et al., 2013; van Wersch and $\mathrm{Li}$, 2019), thus facilitating functional diversification towards new recognition specificities. Indeed, while NLR-coding genes anyways represent one of the most rapidly evolving gene families in plants, several RPP loci stand out as they were identified as particularly prone to variation and rearrangements in Arabidopsis (Van de Weyer et al., 2019; Jiao and Schneeberger, 2020; Lee and Chae, 2020). Altogether, diversified and rapidly evolving NLR loci thus appear particularly prone to induce autoimmunity in intraspecific $\mathrm{HI}$.

The RPP1 locus, also referred to as DANGEROUS MIX2 (DM2), has been identified as a major hotspot for autoimmunity, and genetically interacts with at least seven distinct loci encoding NLR and non-NLR proteins (Alcazar et al., 2010; Tahir et al., 2013; Chae et al., 2014; Stuttmann et al., 2016). Interestingly, while e.g. RPP1 ${ }^{\mathrm{WsB}}$ (from accession Wassilewskija) and RPP1 ${ }^{\mathrm{Nd}}$ (from accession Niederzenz) confer Hpa resistance, beneficial immune functions were not reported for the autoimmunity-inducing "risk alleles" (originating from accessions Ler, Uk-1, Bla-1, S. Tyrol and Dog 4). The RPP1/DM2 locus in accession Ler (RPP1/DM2 ${ }^{\mathrm{Ler}}$ ) encodes seven to eight full-length TNLs. Respective genes are referred to as RPP1-like R1-R8 or DM2a-DM2h, with the latter nomenclature utilized hereafter (Alcazar et al., 2009; Chae et al., 2014). DM2 ${ }^{\text {Ler }}$ causes $\mathrm{HI}$ when combined with alleles of the receptor kinase STRUBBELIG-RECEPTOR FAMILY3 (SRF3) from the South Asian accessions Kashmir and Kondara (Alcazar et al., 2009; Alcazar et al., 2010). Furthermore, an EMS-induced allele of an O-acetylserine (thiol) lyase (old3-1) and ectopic expression of the immune regulator EDS1 in fusion with yellow fluorescent protein and a nuclear localization signal (EDS1-YFP ${ }^{N L S}$ ) induce autoimmunity in presence of $D M 2^{\text {Ler }}$ (Tahir et al., 2013; Stuttmann et al., 2016). We previously identified $d m 2 h$ alleles in an EMS screen for genetic suppressors of EDS1-YFP ${ }^{N L S}$-induced autoimmunity and showed that DM2 $h$ was also essential for SRF3and old3-1-induced autoimmunity (Stuttmann et al., 2016). Until recently, functional studies of risk loci were hampered by the complexity of the respective gene clusters, the similarity between the NLR genes and the strong dosage-dependent effects of transgenic expression of single NLRs. The contribution of risk loci to natural pathogen resistance and synergistic and/or epistatic interactions between risk locus-encoded NLRs remain therefore largely unexplored. In addition, the molecular mechanisms underlying autoimmune induction are unknown.

To explore the contribution of risk NLRs to pathogen resistance and autoimmunity and to reveal mechanisms of risk NLR activation, we genetically dissected the $D M 2^{\text {Ler }}$ cluster, and re-constituted activation of a DM2 risk NLR in heterologous expression assays. Relying on unique combinations of $D M 2$ genes generated by genome editing in the background of the native Ler accession, we show that the single DM2h immune receptor is necessary and sufficient in all three cases of autoimmunity induced by EDS1-YFPNLS, old3-1 and SRF3. However, we failed to uncover any relevance of the DM2 ${ }^{\text {Ler }}$ encoded TNLs for resistance to model pathogens. In addition, we functionally evaluated activation of a risk allele by an inducer, EDS1-YFP NLS, in Nicotiana benthamiana Agroinfiltration assays and in stable transgenic Arabidopsis. Our data suggest that activation of DM2h occurs by similar mechanisms as for classical sensor NLRs. Intriguingly, we provide evidence that the capacity to activate the NLR and to trigger autoimmunity is unrelated to the physiological activity of the inducer (here, EDS1/EDS1-YFPNLS). We therefore propose that autoimmune induction may, at least in some cases, rely on stochastic interactions of a non-native protein with an immune receptor. This emphasizes the importance of 
bioRxiv preprint doi: https://doi.org/10.1101/2020 11.01.363895; this version posted November 2, 2020. The copyright holder for this preprint (which was not certified by peer review) is the author/funder, who has granted bioRxiv a license to display the preprint in perpetuity. It is made available under aCC-BY-ND 4.0 International license.

exercising caution when drawing conclusions regarding the immune function of a protein based on its ability to trigger an autoimmune response.

\section{Results}

\section{Analysis of nde-type suppressor mutants: $D M 2 h$ is the main locus required for autoimmunity induced by an EDS1-YFPNLS fusion}

Our screen for genetic suppressors of EDS1-YFP ${ }^{N L S}$-induced autoimmunity previously identified $~ 55$ near death experience (nde) mutant lines (Stuttmann et al., 2016). To further elucidate the genetic requirements of autoimmune induction, we analyzed remaining nde lines. First, we Sanger-sequenced $D M 2 h$ in 30 selected phenotypically stable nde mutant lines. Strikingly, 25/30 lines carried independent mutations within DM2h (Figure 1a, Table S1). We concluded that $D M 2 h$ was the main gene required for EDS1-YFP ${ }^{N L S}$-induced autoimmunity targeted in our suppressor screen. The predicted $D M 2 h$ gene model encompasses six exons, and encodes for a canonical TNL-type immune receptor (Figure 1a). TIR and NB-ARC domains are highly homologous among TNLs, and the three nde mutations mapping to these domains affected conserved residues (Figure S1). Most nde mutations affected residues located to the more divergent LRR domain and the LRR-adjacent C-terminal region (Figure 1a). Interestingly, we identified two nonsense mutations (W1129*, W1133*) that truncate DM2h by approximately 40 amino acids.

From the remaining five $n d e$ lines harboring wild type $D M 2 h$, we focused on nde2. By a combination of mapping-by-sequencing (using SHORE ; Schneeberger et al., 2009) and recombination mapping, we narrowed nde 2 down to an interval on chromosome 4 that lacked non-synonymous candidate SNPs according to whole-genome resequencing data. However, the candidate interval coincided with the insertion site of the EDS1-YFP ${ }^{\text {NLS }}$ transgene (At4g28490; Stuttmann et al., 2016). Thus, suppression of autoimmunity in nde2 is most likely caused by downregulation of EDS1-YFPNLS expression. Identification of causal mutations in remaining nde lines was not attempted.

Targeting of $D M 2 h$ in most $n d e$ lines suggests that autoimmune induction by EDS1-YFP ${ }^{\text {NLS }}$ does not require additional $D M 2$-encoded NLRs. We demonstrated this also by comparing autoimmunity in near-isogenic lines ectopically expressing $D M 2 h$ and containing $D M 2^{\text {Ler }}$ or $D M 2^{\text {Col }}$ (Figure $1 \mathrm{~b}, \mathrm{c}$ ). A complementation line expressing $D M 2 h$ under control of its native promoter in the $d m 2 h^{\text {nde1-1 }}$ background (Col eds1-2 dm2 $h^{\text {nde1-1 }} n p: g E D S 1-Y F P^{N L S} n p: g D M 2 h$; Col eds1-2 is a near isogenic line that also contains $D M 2^{\text {Ler; }}$; Stuttmann et al., 2016) was crossed to Col, and lines containing $D M 2^{\mathrm{Col}}$ and both transgenes were selected (EDS1-YFP ${ }^{N L S}, D M 2 h$; Figure 1c). Autoimmunity was induced similarly when plants containing $D M 2^{\text {Ler }}$ or $D M 2^{\text {Col }}$ (and ectopically expressing DM2h and EDS1-YFP ${ }^{\text {NLS }}$ ) were shifted to low temperatures (Figure $1 b$ ). Thus, the $D M 2 a-g$ genes from the $D M 2^{\text {Ler }}$ region have weak or no contribution to necrosis induction, and $D M 2 h$ is necessary and sufficient for autoimmunity induced by EDS1-YFP NLS.

\section{Generation of $D M 2^{L}{ }^{\mathrm{L} r}$ mutant variants by genome editing}

To dissect the functions of $D M 2$ genes in autoimmunity and resistance to pathogens, we generated derivatives of the $D M 2^{\text {Ler }}$ cluster by genome editing (Ordon et al., 2017; Ordon et al., 2019). The genetic 
bioRxiv preprint doi: https://doi.org/10.1101/2020.11.01.363895; this version posted November 2, 2020. The copyright holder for this preprint (which was not certified by peer review) is the author/funder, who has granted bioRxiv a license to display the preprint in perpetuity. It is made available under aCC-BY-ND 4.0 International license.

makeup of mutant lines is summarized in Figure 2 (see Figure S2 for details). $d m 2 c-4$ and $d m 2 h-1$ are single mutant lines. The $\Delta d m 2 a-g$ mutant line expresses only $D M 2 h$ from its native genomic locus. $\Delta d m 2-11$ ( $70 \mathrm{~kb}$ deletion) and $\Delta d m 2-3$ ( $120 \mathrm{~kb}$ deletion) lack all DM2 genes, and also regions encompassing At3g44610-620 and At3g44680-700 were deleted in $\Delta d m 2-3$ (Figure 2). Some mutant lines were initially generated in the old3-1 mutant background, and wild type OLD3 (OASTL-A1; AT4G14880) was subsequently introduced by crossing to Ler (Tahir et al., 2013; Ordon et al., 2017). Notably, $\triangle d m 2-3$ mutant plants (lacking DM2 and flanking genes) were smaller at the seedling stage up to approximately 3-4 weeks and flowered earlier than control plants under short day conditions (Figure S2). These phenotypes were independent of OLD3/old3-1, and were not detected in $d m 2-11$ plants. Thus, the observed differences are likely due to deletion of the cluster-flanking genes in $\Delta d m 2-3$.

\section{The $D M 2^{\mathrm{L} e r}$ region contributes to oomycete resistance, but this is independent of the RPP1-like NLRs}

Maintenance of the $D M 2^{\text {Ler }}$ haplotype in natural populations despite its potentially detrimental effects on plant fitness in combination with certain genetic backgrounds (Alcazar et al., 2014; Atanasov et al., 2018) suggests it may confer selective advantages. We tested a potential role of the $D M 2^{\text {ter }}$ region in natural pathogen resistance by challenging $\Delta d m 2-3$ mutant plants (lacking $D M 2$ and flanking genes) with virulent Pseudomonas syringae bacteria (Pst DC3000; Figure 3a) and compatible and incompatible Hpa isolates Cala2 and Emwa1, respectively (Figure 3b,c). The Ler rar1-13 line was included as a control for moderately impaired immunity (Muskett et al., 2002). As expected, Pst DC3000 bacteria grew better in rar1-13 mutant plants, and also in old3-1 mutant plants (compare $\Delta d m 2-3$ and $\Delta d m 2-3$ old3-1; Tahir et al., 2013). However, Pst DC3000 grew to similar levels in wild type and $\Delta d m 2-3$ mutant plants, indicating that the $D M 2^{\text {Ler }}$ haplotype does not contribute to Pst DC3000 resistance (Figure 3a). In contrast, $\Delta d m$ 2-3 mutant plants supported higher sporulation of the compatible Hpa isolate Cala2, and this phenotype was aggravated by presence of old3-1 (Figure 3b). Similarly, isolate Emwa1, which is resisted by RPP4/RPP8 in accession Ler (Holub et al., 1994), showed enhanced outgrowth at infection sites and provoked less-confined, expanded HRs in $\Delta d m 2-3$ mutant plants in comparison to wild type Ler (Figure 3c). This phenotype was more severe than that of the rar1-13 mutant, which was only weakly impaired in resistance to Emwa1 under our conditions.

We assumed that one or several Hpa effectors might be weakly recognized by RPP1-like NLRs encoded at the $D M 2^{\text {Ler }}$ locus. We used infection with Hpa isolate Emwa1 and Trypan Blue staining to analyze contributions of $D M 2^{\text {Ler }}$ genes to Hpa resistance in more detail (Figure $3 c$ ). $\Delta d m 2 a-g, d m 2 c$ and $d m 2 h$ mutant plants were not impaired in resistance (Figure 3c). Unexpectedly, also the $\Delta d m 2-11$ mutant line, which carries a deletion of all DM2 genes, was as resistant as Ler wild type to Hpa Emwa1 (Figure 3c). This suggests that one of the flanking genes present in $\Delta d m 2-11$, but absent in $\Delta d m 2-3$ (Figure 2), directly or indirectly contributes to Hpa resistance. HISTONE DEACETYLASE9 (At3g44680) may be a most likely candidate, as it was reported to regulate flowering time (Figure S2; Kim et al., 2013; Park et al., 2019) and also plant resistance responses (Yang et al., 2020).

\section{DM2h is necessary and sufficient for autoimmunity induced by old3-1 and SRF3}

The contribution of individual $D M 2^{\text {Ler }}$ genes to temperature-dependent autoimmunity induced by old3-1 or SRF3 ${ }^{\text {Kas/Kond }}$ was not fully clarified (Alcazar et al., 2009; Alcazar et al., 2010; Tahir et al., 2013; Stuttmann et al., 2016; Atanasov et al., 2018). We therefore analyzed lines containing old3-1 or 
bioRxiv preprint doi: https://doi.org/10.1101/2020.11.01.363895; this version posted November 2, 2020. The copyright holder for this preprint (which was not certified by peer review) is the author/funder, who has granted bioRxiv a license to display the preprint in perpetuity. It is made available under aCC-BY-ND 4.0 International license.

$S R F 3^{\text {Kond }}$ and varying complements of $D M 2$ genes for autoimmune induction (Figure 4). Different lines were compared phenotypically, and salicylic acid (SA) levels or defense marker transcript levels were determined to quantitatively assess autoimmunity induction. There were no phenotypic differences between old3-1 plants expressing only DM2h from its native genomic locus ( $\Delta d m 2 a-g$ old3-1) or those also containing additional DM2 genes (Figure $4 a, b$ ). However, SA levels were mildly reduced in $\Delta d m 2 a-g$ old3-1 plants after temperature shift compared to old3-1 plants (Figure 4b). Similarly, autoimmune hybrids obtained from crosses to Kondara (to introduce SRF3 ${ }^{\text {Kond }}$ ) and containing either the full $D M 2^{\text {Ler }}$ cluster or only $D M 2 h$ (in the $\Delta d m 2 a-g$ line) were phenotypically indistinguishable, and expression of the defense marker gene Pathogenesis Related 1 (PR1) was slightly reduced in necrotic hybrids lacking DM2a-g (Figures $4 \mathrm{c}, \mathrm{d}$ ). In summary, the data do not suggest a major role for DM2a-g. Thus, $D M 2 h$ is sufficient for autoimmune induction not only by EDS1-YFP ${ }^{\text {NLS }}$ (Figure 1 ), but also by old3-1 and SRF3 ${ }^{\text {Kond }}$.

\section{Functional analysis of DM2h}

Our genetic analyses showed that DM2h mediates autoimmunity induced by EDS1-YFP ${ }^{\text {NLS }}$, old3-1 and $S R F 3^{\text {Kas/Kond }}$ (Figures 1,4). We wondered whether there were mechanistic differences between the risky $\mathrm{DM} 2 \mathrm{~h}$ NLR, prone to autoimmune induction, and previously characterized sensor TNLs. We therefore set out for functional analysis of DM2h.

We relied on heterologous expression in Nicotiana benthamiana ( $\mathrm{Nb}$; by Agroinfiltration) for functional analysis. On the one hand, we used a TIR domain fragment, DM2 $\mathrm{h}_{1-279}$, which induces EDS1-dependent cell death in $N b$ (Gantner et al., 2019). On the other hand, we developed a co-expression assay to functionally interrogate the DM2h full length protein (Figure S4): Expression of DM2h together with EDS1-YFP NLS or old3-1, but not expression of the proteins alone or co-expression of DM2h with EDS1-YFP or OLD3, induced HR-like cell death in Nb. Co-expression of DM2h with SRF3 ${ }^{\text {Kond }}$, described to provoke autoimmunity recessively and only in absence of a compatible SRF3 allele in Arabidopsis (Alcazar et al., 2010), did also not induce HR-like cell death. Thus, cell death induction in Nb faithfully recapitulated activation of DM2h-dependent autoimmunity in Arabidopsis, and can be used as a proxy for DM2h activation and initiation of TNL-mediated defenses.

$D M 2 h$ encompasses an additional 5'exon present in some RPP1 homologs (Figure 1a; Meyers et al., 2003; Chae et al., 2014). The encoded N-terminal extension contains a predicted myristoylation motif (including the critical $\mathrm{G} 2$ residue) and a bipartite nuclear localization signal (Stuttmann et al., 2016). Furthermore, DM2h contains a GK diresidue critical for ATP binding within the P-loop and a characteristic SH motif predicted to be required for TIR-TIR interactions (Bonardi et al., 2011; Williams et al., 2014; Burdett et al., 2019).

A variant of a DM2h-279-GFP fusion carrying exchanges (to alanine) in the $\mathrm{SH}$ motif (SH-AA) accumulated to wild-type levels on western blots, but did not induce any plant reactions (Figure 5a,b), suggesting that DM2 $\mathrm{h}$ cell death activity may involve TIR-TIR interactions. A DM2 $\mathrm{h}_{1-279-G F P ~ G 2 A}$ variant was not stable (Figure $5 b$ ). G2S and G2E variants accumulated to low levels, but still induced residual cell death (Figure $5 \mathrm{a}, \mathrm{c}$ ), arguing against a requirement for myristoylation. This was further examined by co-expressing a DM2 $c^{\text {TIR }}$-DM2 $\mathrm{h}^{\text {NB-LRR }}$ chimeric protein together with EDS1-YFP ${ }^{\text {NLS }}$ and old3-1 (Figure 5c). DM2c is highly similar to DM2h ( $80 \%$ amino acid identity in the region encoded by the $\mathrm{DM} 2 \mathrm{c} / \mathrm{h}$ chimeric construct), but lacks the $\mathrm{N}$-terminal extension of $\mathrm{DM} 2 \mathrm{~h}$ and does not contain a predicted myristoylation motif or NLS. In co-expression assays, the DM2 $\mathrm{c}^{\mathrm{TIR}}-\mathrm{DM} 2 \mathrm{~h}^{\mathrm{NB}-\mathrm{LRR}}$ chimeric protein could 
bioRxiv preprint doi: https://doi.org/10.1101/2020.11.01.363895; this version posted November 2, 2020. The copyright holder for this preprint (which was not certified by peer review) is the author/funder, who has granted bioRxiv a license to display the preprint in perpetuity. It is made available under aCC-BY-ND 4.0 International license.

mediate EDS1-YFPNLS- and old3-1-induced cell death, although this was mildly reduced in comparison to co-expression of native DM2h (Figure $5 \mathrm{c}$ ). Taken together, these data suggest that the $\mathrm{G} 2$ residue is critical for stability, while myristoylation is not required for cell death executed by DM2h. Further, DM2h P-loop variants (G301A, K302R) were tested in co-expression assays (Figure $5 \mathrm{~d}$ ). While single amino acid exchanges strongly reduced the DM2h cell death activity, it was fully abolished when both residues were simultaneously exchanged in DM2h(GK-AR). DM2h, which often produced two signals on western blots, and P-loop variants accumulated to similar levels, suggesting that amino acid exchanges did not impair protein stability (Figure 5e; please note that cell death assays were conducted with untagged proteins, as tagged variants (e.g. $\mathrm{N}$ - and C-terminal 6xHA and GFP tags tested) were not or only weakly functional in co-expression assays).

In addition, we aimed to determine the subcellular localization of DM2h by live cell imaging. No fluorescence signal was detected when the full length protein, in fusion to GFP, was expressed by Agroinfiltration. However, strong fluorescence in nuclei was observed when the DM2h $\mathrm{h}_{1-279}$-GFP TIR fragment was expressed in $\mathrm{Nb}$ (Figure 5f). Similarly, DM2h was detected primarily in nuclei when examining a transgenic Arabidopsis line expressing DM2h-YFP under 355 promoter control in accession Col (Figure 5g).

Last, we determined the genetic requirements of DM2h-mediated cell death in $\mathrm{Nb}$ co-expression assays using an Nbeds1 line and a newly generated Nbnrg1 mutant line (Figure S6). Plant reactions induced upon co-expression of DM2h with EDS1-YFP ${ }^{\mathrm{NLS}}$ or old3-1 were fully and partially abolished in eds1 and nrg1 mutant plants, respectively (Figure $5 \mathrm{~h}$ ).

Summarizing, our data suggest that induction of immune responses by DM2h may involve TIR-TIR interactions and requires an intact P-loop (Figure 5c,d), but not myristoylation (Figure 5a, c). Potential myristoylation is also not supported by localization studies, which suggest the nucleus as predominant compartment for DM2h (Figure $5 f, g$ ). Induction of downstream resistance responses by DM2h, here tested in $\mathrm{Nb}$, requires EDS1 complexes and the helper NLR NRG1 (Figure $5 \mathrm{~h}$ ). Our data thus do not support mechanistic differences between the autoimmune risk NLR DM2h and classical sensor NLRs, as they recapitulate previously reported analyses of RPP1 orthologs functioning in Hpa resistance (Krasileva et al., 2010; Schreiber et al., 2016; Zhang et al., 2017) and also other sensor TNLs (e.g., BurchSmith et al., 2007; Wirthmueller et al., 2007; Williams et al., 2014; Saile et al., 2020).

\section{EDS1-YFPNLS operates upstream of DM2h}

EDS1, in its function as an immune regulator, is assumed to signal at the level of or immediately downstream of activated TNL-type receptors. However, $\mathrm{Nb}$ co-expression assays (Figure 5) place AtEDS1-YFP ${ }^{\mathrm{NLS}}$ upstream of DM2 $\mathrm{h}$ in cell death induction, as Arabidopsis EDS1 cannot exert immune signaling in $N b$ (Gantner et al., 2019; Lapin et al., 2019). This is also supported by the fact that EDS1-YFP ${ }^{\text {NLS }}$-induced cell death is abolished in Nbeds1 plants (Figure $5 \mathrm{~h}$ ).

We made use of a previously identified loss-of-function allele of Arabidopsis EDS1, EDS1(F419E), to further disentangle EDS1 functions in downstream immune signaling from its role in activation of $\mathrm{DM} 2 \mathrm{~h}$ in the context of the EDS1-YFP NLS fusion protein. EDS1(F419E) corresponds to a mutation identified in tomato EDS1 (S/EDS1(F435E)), which abolishes EDS1 signaling functions, but does not interfere with assembly of EDS1 complexes with PAD4 or SAG101 (Gantner et al., 2019; Lapin et al., 2019). When expressed together with DM2h in Nb, EDS1-YFP NLS and the corresponding F419E variant 
bioRxiv preprint doi: https://doi.org/10.1101/2020.11.01.363895; this version posted November 2, 2020. The copyright holder for this preprint (which was not certified by peer review) is the author/funder, who has granted bioRxiv a license to display the preprint in perpetuity. It is made available under aCC-BY-ND 4.0 International license.

induced cell death to similar extents, while EDS1-YFP and EDS1-YFP nls did not (Figure 6a). We also analyzed positioning of EDS1-YFP NLS in Arabidopsis autoimmune induction by temperature shift experiments using primary transformants (Figure 6b). EDS1-YFP ${ }^{\text {NLS }}$ and an EDS1-YFP ${ }^{\text {NLS }}$ (F419E, L258A, L262A) variant (under native promoter control) were combined with DM2h by transforming the constructs into wild type Ler plants and/or the Ler eds1-2 mutant line. The L258A and L262A exchanges reduce the affinity of EDS1 to PAD4 and SAG101 (Wagner et al., 2013). They were combined with F419E in the transformation construct to avoid dominant negative effects from interference with the assembly of endogenous EDS1-PAD4/SAG101 complexes. EDS1-YFP ${ }^{\text {NLS }}$ induced autoimmunity among primary transformants in the Ler eds1-2 background, as expected (Figure 6b). In contrast, EDS1-YFP ${ }^{\text {NLS }}$ (F419E, L258A, L262A) did not induce autoimmunity in eds1-2 plants, but in wild-type Ler background (Figure 6b). This confirms that EDS1(F419E) is not functional in downstream immune signaling (Lapin et al., 2019), and demonstrates it is still capable of activating DM2h to induce autoimmunity in presence of signaling-competent, endogenous EDS1 complexes in Arabidopsis. The F419E mutation did not interfere with protein stability or alter protein subcellular localization (Figure S7). Thus, cell death-based $\mathrm{Nb}$ assays and stable Arabidopsis transformants provide strong evidence for a position of EDS1-YFP ${ }^{\text {NLS }}$ upstream of DM2h in the activation of the immune receptor. Concomitantly, we conclude that DM2h activation by EDS1-YFP NLS is unrelated to and independent of EDS1 immune signaling functions, albeit DM2h, as a classical TNL, requires EDS1 signaling functions for downstream signal relay.

\section{Identification of features within EDS1-YFPNLS required for DM2h activation}

The observations that DM2h functions similar to NLRs conferring natural pathogen resistance (Figure 5) and that EDS1-YFP NLS operates upstream of the DM2h immune receptor (Figure 6) suggest that the fusion protein might mimic an effector activating a sensor NLR. We therefore hypothesized that EDS1YFPNLS contained a surface or epitope-like feature specifically recognized by the DM2h immune receptor.

We generated EDS1 expression constructs differing in the NLS (as EDS1-YFP did previously not induce autoimmunity; Figure 5; Stuttmann et al., 2016) or the linker connecting EDS1 with the YFP moiety (Figure 7a). Expression constructs encoded for an SV40 NLS lacking two terminal glycine residues, which were contained in the original EDS1-YFP NLS fusion, or an NLS from c-myc, the human cancer protein. Additionally, constructs encoded either a 16 aa linker derived from the Gateway attB recombination site, or a short Ala-Ser-Ala (ASA) linker (Figure 7a). When tested in $\mathrm{Nb}$ co-expression assays, all fusion proteins containing the Gateway-linker activated DM2h and induced cell death, while those containing the ASA linker did not (Figure 7b). EDS1-YFP ${ }^{\text {NLS }}$ variants showed similar subcellular localizations, and were not impaired in protein accumulation (Figure S8). EDS1-YFP ${ }^{\text {NLS }}$ variants were further tested for their capacity to mediate TNL signaling and to induce autoimmunity in Arabidopsis. Constructs for expression of EDS1-YFPNLS variants, under EDS1 promoter control, were transformed into the Col eds1-2 line (containing DM2 ${ }^{\text {Ler }}$, Figure $1 \mathrm{~b}, \mathrm{c}$ ). Infection studies with primary transformants and $\mathrm{Hpa}$ isolate Cala2 showed that all variants could complement impaired RPP2-mediated resistance of the Col eds1-2 line, and were thus functional in the context of downstream TNL signaling (Figure 7c). However, in agreement with results obtained in $\mathrm{Nb}$ co-expression assays, only those variants containing the Gateway linker also induced autoimmunity in temperature-shift experiments (Figure 7d). It is thus minor differences within the EDS1-YFP ${ }^{\text {NLS }}$ fusion protein that differentiate a DM2h- 
bioRxiv preprint doi: https://doi.org/10.1101/2020.11.01.363895; this version posted November 2, 2020. The copyright holder for this preprint (which was not certified by peer review) is the author/funder, who has granted bioRxiv a license to display the preprint in perpetuity. It is made available under aCC-BY-ND 4.0 International license.

activating variant from one that is compatible with $\mathrm{DM} 2 \mathrm{~h}$. These differences are not linked to EDS1 immune signaling functions.

\section{Discussion}

A number of NLR-coding loci, often referred to as risk loci or DANGEROUS MIX loci, are involved in induction of autoimmunity in diverse scenarios. Among these, $\mathrm{DM} 2^{\mathrm{Ler}}$ is unique because of its role in at least three independent cases of autoimmunity, in genetic interactions with natural and EMSinduced alleles, or an ectopically expressed EDS1-YFP ${ }^{\text {NLS }}$ protein (Alcazar et al., 2009; Tahir et al., 2013; Stuttmann et al., 2016). In this study, the $D M 2 h$ gene from the $D M 2^{\text {Ler }}$ cluster was not only identified as the exclusive target of our EDS1-YFP ${ }^{\text {NLS }}$ suppressor screen (Figure 1), but also revealed as major driver of autoimmune induction when expressed from its endogenous genomic locus (in a $\Delta d m 2 a-g$ mutant line) together with old3-1 or SRF3 ${ }^{\text {Kond }}$ (Figure 4; Atanasov et al., 2018). Thus, we demonstrate that a single NLR is necessary and sufficient in all three scenarios of autoimmune induction. This raises the questions how autoimmune risk NLRs may be different from classical sensor NLRs and how DM2h becomes activated in presence of different incompatible alleles.

\section{Sensor NLRs vs. risk-NLRs: Any evidence for conceptual differences?}

RPP1-like NLRs encoded at the DM2 locus in Arabidopsis accessions and conferring resistance to different $\mathrm{Hpa}$ isolates were extensively characterized in previous studies (Rehmany et al., 2005; Krasileva et al., 2010; Chou et al., 2011; Steinbrenner et al., 2015; Goritschnig et al., 2016; Schreiber et al., 2016; Zhang et al., 2017; Horsefield et al., 2019; Wan et al., 2019). Summarizing our current understanding, activation of RPP1-dependent immune responses depends on $i$ ) direct interaction of the recognized effector with the receptor's LRR domain, ii) receptor oligomerization, controlled by ATP-binding at the P-loop, iii) TIR-TIR interactions via the AE and DE-interfaces, iv) enzymatic (NADase) activity dependent on a critical TIR domain glutamate residue. It is tempting to speculate that also for RPP1, formation of resistosome complexes regulates the TIR domain enzymatic activity (Martin et al., 2020b). Furthermore, RPP1-mediated resistances depend on EDS1 complexes and helper NLRs (Wagner et al., 2013; Qi et al., 2018; Jubic et al., 2019). Here, we reinforce and add to previous analyses of the RPP1-like risk NLRs DM2 $\mathrm{d}^{\mathrm{Uk}-1}$ and DM2 ${ }^{\text {Bla-1 }}$ (Chae et al., 2014; Tran et al., 2017) by functional analysis of DM2h ${ }^{\text {Ler }}$ (Figure 5). Our results support that also DM2h activation depends on a functional P-loop and TIR-TIR interactions. Additionally, our $\mathrm{Nb}$ assays reveal that DM2h-mediated responses are, fully and partially, dependent on presence of EDS1 complexes and the NRG1 helper NLR, respectively. Last, we identify the nucleus as most likely compartment for DM2h localization (Figure $5 \mathrm{~h}, \mathrm{~g}$ ), which is in agreement with previous analyses of the TNLs N and RPS4 (Burch-Smith et al., 2007; Wirthmueller et al., 2007). Overall, our results do thus not support differences, at the mechanistic level, between autoimmune risk-NLRs and sensor NLRs characterized in pathogen resistance.

In absence of mechanistic differences, what could be the basis for the frequent involvement of certain NLR loci, such as DM2, in autoimmunity? The DM2 locus and additional complex NLR loci stand out, at the genome-scale, for their complexity and evolutionary dynamics (Chae et al., 2014; Van de Weyer et al., 2019; Jiao and Schneeberger, 2020; Lee and Chae, 2020). Thus, a disproportionally large number of diversified RPP1-like NLRs may be encoded within the global Arabidopsis gene pool, which may explain to some extent the incidence of $D M 2$ and other complex NLR clusters in autoimmunity. An alternative explanation for why certain highly variable NLRs are particularly prone to autoimmune 
bioRxiv preprint doi: https://doi.org/10.1101/2020.11.01.363895; this version posted November 2, 2020. The copyright holder for this preprint (which was not certified by peer review) is the author/funder, who has granted bioRxiv a license to display the preprint in perpetuity. It is made available under aCC-BY-ND 4.0 International license.

induction could be that they differ in their activation kinetics. In the equilibrium-based switch model, NLRs cycle between the ADP-bound OFF and the ATP-bound ON state also in absence of a recognized effector (Bernoux et al., 2016). However, baseline activation levels differ between NLRs, and signaling capacities can be tuned to less responsive or hyper-responsive by altering intramolecular interactions (Qi et al., 2012; Bernoux et al., 2016). Risk NLRs may, at least in some cases, be shifted particularly far towards the ON/ hyper-responsive state in comparison to evolved sensor NLRs. This may place them directly at the brink of full activation, so that spurious interactions or even cellular perturbations may be sufficient for immune receptor activation and resistosome formation. The concept of cellular perturbation as an NLR trigger is, e.g., supported by an accession-specific TNL allele inducing autoimmunity under osmotic stress (Ariga et al., 2017). Activation of NLRs by altered cell physiology could provide one possible explanation for the apparent promiscuous activation properties of DM2h as well as other risk NLRs, such as SUPPRESSOR OF NPR1-1, CONSTITUTIVE1 (SNC1) (see e.g. Chakraborty et al., 2018).

\section{$\mathrm{DM} 2 \mathrm{~h}$ as a guardian NLR, or direct binder?}

The most plausible scenarios for the induction of DM2h-mediated autoimmunity are direct activation of the DM2h immune receptor through physical interaction with gene products of incompatible alleles or disturbance of guard-guardee pairs (Rodriguez et al., 2016; Kourelis and van der Hoorn, 2018). While experimental data supporting either scenario are scarce, we think that a number of arguments favor direct activation. RPP1 receptors conferring Hpa resistance directly bind corresponding ARABIDOPSIS THALIANA RECOGNIZED1 (ATR1) effector proteins via their LRR domain, and variation at RPP1 and ATR1 loci and structure-function analyses support ongoing co-evolution of receptor and ligand surfaces (Rehmany et al., 2005; Krasileva et al., 2010; Chou et al., 2011; Steinbrenner et al., 2015; Goritschnig et al., 2016). There does not appear to be any difference per se between NLRs encoded at risk loci and those with characterized immune functions, and inducers of autoimmunity demonstrate the same behavior of allele-specific receptor activation as pathogenic ATR1 effectors (Figures 5,7; Tahir et al., 2013; Alcazar et al., 2014; Chae et al., 2014). Genetic screens have so far also not revealed further components required for DM2h-mediated autoimmunity, as might be expected for a scenario of indirect activation (this work; Stuttmann et al., 2016; Atanasov et al., 2018). Maybe most significantly, there is little support for a function of DM2h as guardian NLR from an evolutionary perspective. Guardian NLRs can be expected to co-evolve with guardees and thus to experience balancing or purifying selection. In contrast, NLRs directly binding cognate effectors are required to rapidly evolve novel specificities to adapt to newly arising effector alleles, and thus underlie diversifying selection which is clearly the case for RPP1-like NLRs. Indeed, Prigozhin et al. (2020) recently proposed that refined NLR clade assignment, coupled with analysis of amino acid diversity in near-allelic series, can be used to computationally discriminate guardian NLRs and direct binders (Prigozhin and Krasileva, 2020). In this analysis, a class of highly variable NLRs contained all the described Arabidopsis autoimmune loci (including DM2h), but not a single guard NLR (Prigozhin and Krasileva, 2020).

It is also worth noting that two of the EMS-induced $d m 2 h$ alleles identified in the $n d e$ mutants, E697K and S703N (Figure 1), locate to the presumably surface-exposed positions on the concave surface of the DM2h-LRR domain (variable positions within the LxxLxLxx LRR consensus sequence, prediction of DM2h LRRs using NLRpredictor; Martin et al., 2020a). These mutations may highlight an interface for the binding of EDS1-YFPNLS on the DM2h-LRR, and it will be interesting to test whether the respective alleles might be specific for EDS1-YFP ${ }^{N L S}$ recognition; in other words, whether they maintain 
bioRxiv preprint doi: https://doi.org/10.1101/2020.11.01.363895; this version posted November 2, 2020. The copyright holder for this preprint (which was not certified by peer review) is the author/funder, who has granted bioRxiv a license to display the preprint in perpetuity. It is made available under aCC-BY-ND 4.0 International license.

responsiveness to old3-1 and/or SRF $3^{\text {Kond }}$. Furthermore, a total of six independent $d m 2 h$ alleles (including two minor truncations) also highlight the importance of the C-terminal non-LRR domain for autoimmune induction by EDS1-YFPNLS. In the recently solved Roq1 cryo-EM structure, this Post-LRR domain contributes to ligand binding together with the LRR (Martin et al., 2020b).

We could not find any support for direct interaction of old3-1 and EDS1-YFP ${ }^{\text {NLS }}$ with DM2h or domains thereof in initial yeast two hybrid and co-immunoprecipitation assays (not shown). However, more sensitive interaction assays suitable for transient interactions, such as split Luciferase or proximity labeling by TurboID (Luker et al., 2004; Branon et al., 2018; Mair et al., 2019; Arora et al., 2020), may be required for revealing a direct interaction between $\mathrm{DM} 2 \mathrm{~h}$ and inducers, as it is known that also NLReffector interactions in pathogen recognition are often highly transient and difficult to capture experimentally (Saur et al., 2019; Song et al., 2020).

\section{Role of autoimmunity risk loci in natural pathogen resistance: Adaptive benefits?}

Despite the potential risk of autoimmunity posed by the highly variable NLRs, they are maintained in the natural gene pool (Bomblies and Weigel, 2007; Alcazar et al., 2014). This suggests they may provide selective advantages in a given environment, potentially also due to a low activation threshold. Here, using CRISPR/Cas lines with different complements of DM2 genes, we failed to show any role of this locus in pathogen resistance (Figure 3 ). This is reminiscent of a previous analysis of $D M 2$ haplotypes (Atanasov et al., 2018). However, in addition to evolutionary and population genetics analyses supporting functional relevance of risk loci (e.g. Chae et al., 2014), amino acid diversity within the LRRs of highly variable NLRs supports that variation does not occur randomly, but is the result of underlying selective pressure. For example, amino acid diversity is higher at surface-exposed positions within the LRR fold and often involves hydrophobic residues which may mediate protein-protein interactions (Prigozhin and Krasileva, 2020). Lastly, considering that risk loci are commonly selected for in breeding programs (Bomblies and Weigel, 2007), we most likely lack appropriate pathosystems to detect beneficial functions of risk loci, or effects may be subtle or masked by redundancy in incompatible interactions. To that end, recent system analyses suggest that $68 \%$ of plant pathogenic Pseudomonas strains are resisted by multiple NLRs in Arabidopsis (Laflamme et al., 2020).

\section{Activation of risk-NLRs by incompatible alleles: EDS1-YFPNLS as a case study}

Our data show that, although EDS1 is a well-known immune regulator required for signaling downstream of activated TNLS, the EDS1-YFP ${ }^{\text {NLS }}$ fusion protein operates upstream of the DM2h immune receptor to induce autoimmunity (Figures 5,6). DM2h activation depends on very specific properties of the fusion protein, i.e. the presence of the Gateway-linker and an NLS, but is independent of EDS1 immune signaling functions (Figures 6,7). Theoretically, DM2h activation could result from disturbance of a guard-guardee pair - EDS1-NLR interactions were reported and also guarding of EDS1 proposed (e.g. Bhattacharjee et al., 2011; Huh et al., 2017) - but, in particular, heterologous Nb assays argue otherwise. Case in point, DM2h activation can be reconstituted in $\mathrm{Nb}$, although EDS1 proteins and functions have diverged between Arabidopsis and Solanaceae (Gantner et al., 2018; Lapin et al., 2019). Accordingly, induction of autoimmunity, at least in this case, is not predictive of immune functions of an incompatible allele. Similarly, activation of DM2h by old3-1 appears to depend on very specific properties of the incompatible allele (a point mutation); an old3 loss-of-function T-DNA allele does not induce autoimmunity (Tahir et al., 2013). Notably, also the activation of immune receptors involved in dominant $\mathrm{HI}$ can often be reconstituted in heterologous $\mathrm{Nb}$ assays, and is limited to very specific alleles of the non-NLR locus in populations (e.g. Chae et al., 2014; Tran et al., 2017; Li et al., 2020). We therefore propose that autoimmunity in negative epistatic interactions involving NLRs may, 
bioRxiv preprint doi: https://doi.org/10.1101/2020.11.01.363895; this version posted November 2, 2020. The copyright holder for this preprint (which was not certified by peer review) is the author/funder, who has granted bioRxiv a license to display the preprint in perpetuity. It is made available under aCC-BY-ND 4.0 International license.

at least in some cases, occur stochastically due to the recognition of corresponding patterns by NLRs. This shall function as a cautionary note for interpretation of dominant autoimmunity, in particular upon involvement of highly variable and thus risky NLRs.

\section{Material and Methods}

\section{Plant material and growth conditions}

$N$. benthamiana plants were cultivated in a greenhouse with a 16-h light period (sunlight and/or IP65 lamps (Philips) equipped with Agro $400 \mathrm{~W}$ bulbs (SON-T); $130-150 \mu \mathrm{E} / \mathrm{m}^{2 *}$ s; switchpoint ;100 $\mu \mathrm{E} / \mathrm{m}^{2 *} \mathrm{~s}$ ), $60 \%$ relative humidity at $24 / 20^{\circ} \mathrm{C}$ (day/night). The Nbeds1 (Nbeds1a-1) mutant line is published (Ordon et al., 2017). Details on Nbnrg1 mutant lines are provided in Figure S3. Arabidopsis thaliana plants were cultivated under short day conditions ( $8 \mathrm{~h}$ light, $23 / 21^{\circ} \mathrm{C}$ day/night, $60 \%$ relative humidity) or in a greenhouse under long day conditions (16h light) for seed set. For suppression of autoimmunity, plants were germinated under short day conditions (7-8 d) and subsequently cultivated in a growth chamber with $28 / 26^{\circ} \mathrm{C}$ day/night temperatures and $12 \mathrm{~h}$ light $\left(\sim 120 \mu \mathrm{E} / \mathrm{m}^{2 *} \mathrm{~s}\right)$. For temperature-shift experiments, plants were moved into a growth chamber with $18 / 16^{\circ} \mathrm{C}$ day/night cycle (12h illumination). For induction of hybrid necrosis (SRF3-DM2 $2^{\text {Ler }}$ ), plants were grown with $14 / 12^{\circ} \mathrm{C}$ day/night temperatures under short day conditions for $4-6$ weeks. Arabidopsis mutant or transgenic lines in the Columbia background (Col eds1-2, EDS1-YFP ${ }^{N L S} \#$ A3 (in eds1-2), dm2 $h^{\text {nde1-1 }}$ (in EDS1-YFP ${ }^{N L S} \# A 3$ ), $n p: D M 2 h$ (in $d m 2 h^{\text {nde1-1 }}$ ) were previously described (Bartsch et al., 2006; Stuttmann et al., 2016). Mutant lines in the Landsberg erecta (Ler) background used in this study were eds1-2 (Aarts et al., 1998), rar1-13 (Muskett et al., 2002) and several lines deficient in genes of the DM2 cluster. DM2-deficient lines were reported previously (Ordon et al., 2017; Ordon et al., 2019) or details are provided in Figure S2. Furthermore, Arabidopsis accessions Kashmir and Kondara were used.

\section{Sequencing of $n d e 1$ alleles, $D M 2 h$ cDNA cloning and multiple sequence alignments} DM2h was PCR-amplified in two fragments using oligonucleotides JS724/1156 and JS1155/725 (Table S2). Amplicons were purified using a column-based kit and sequenced using oligonucleotides JS1153/729/731 and JS733/1381, respectively. To clone the DM2h cDNA, DM2h was first transiently expressed in $\mathrm{Nb}$ using a gDNA fragment under $35 \mathrm{~S}$ promoter control. Tissues were used for RNA extraction $2 \mathrm{dpi}$, and cDNA was generated using RevertAid Reverse Transcriptase (Thermo). DM $2 h$ was amplified from cDNA in five fragments to eliminate internal Bpil restrictions sites (domestication) during cloning, and also to prune the second intron, which was retained in several fragments cloned from cDNA prepared from Nb (Primers JS972/973, JS729/1035, JS1036/974, JS975/976, JS977/978). Fragments were subcloned in pUC57 (cut/ligation with either Smal or EcoRV), sequence-verified and combined in plCH41308 by a Bpil cut/ligation reaction (Engler et al., 2014). The final construct, pJOG273, was again verified by sequencing, and used as template for all further clonings. Multiple sequence alignments were generated using tcoffee (http://www.tcoffee.org/), and rendered using ESPript (http://espript.ibcp.fr; Robert and Gouet, 2014). 
bioRxiv preprint doi: https://doi.org/10.1101/2020.11.01.363895; this version posted November 2, 2020. The copyright holder for this preprint (which was not certified by peer review) is the author/funder, who has granted bioRxiv a license to display the preprint in perpetuity. It is made available under aCC-BY-ND 4.0 International license.

\section{Infection assays and salicylic acid measurements}

Infection assays with Hyaloperonospora arabidopsidis (isolates Emwa and Cala) were conducted as previously described (Stuttmann et al., 2011). For infection assays with Pst DC3000, bacteria resuspended in $10 \mathrm{mM} \mathrm{MgCl}_{2}$ were syringe-infiltrated into leaves of $4-6$ week-old Arabidopsis plants at an $\mathrm{OD}_{600}=0.0002$. For day 0 , samples were taken $\sim 3 \mathrm{~h}$ after infiltration, and 4 replicates each consisting of 3 leaf discs were processed. On day 3, 8 replicates were used. Leaf discs were shaken in $10 \mathrm{mM} \mathrm{MgCl}_{2}$ containing $0.01 \%$ Silwet for 2 - 3h, serial dilution series were prepared and plated for determination of colony forming units (cfu). For statistical analyses, data was normalized and/or transformed, and ANOVA with Tukey post-hoc test were used. Metabolite extractions for SA measurements were done essentially as described previously (Balcke et al., 2017). Briefly, homogenized frozen material was cryo-extracted twice using $900 \mu \mathrm{L}$ cold dichloromethane/ethanol and $150 \mu \mathrm{L}$ aqueous hydrochloric acid buffer ( $\mathrm{pH}$ 1.5). The organic phase was collected and the extraction residue was extracted again with tetrahydrofurane. Both extracts were combined and dried in a nitrogen stream. The dried residues were resuspended in $180 \mu \mathrm{L} 80 \%$ methanol and centrifuged before injection. SA was measured using a Nucleoshell RP18 column (Macherey \& Nagel) on a Waters ACQUITY UPLC System (flow rate $400 \mu \mathrm{L} / \mathrm{min}$, column temperature $40{ }^{\circ} \mathrm{C}$ ). Eluents $\mathrm{A}$ and $\mathrm{B}$ were aqueous $0.3 \mathrm{mmol} / \mathrm{L} \mathrm{NH} 4 \mathrm{HCOO}$ (adjusted to $\mathrm{pH} 3.5$ with formic acid) and acetonitrile, respectively. Elution was performed as following: 0-2 min 5\% eluent B, 2-19 min linear gradient to 95\% B, 19-24 min 95\% B. Mass spectrometric detection after electrospray ionization was performed via MS-TOF-SWATHMS/MS (TripleToF 5600, both AB Sciex $\mathrm{GmbH}$ ) operating in negative ion mode and controlled by Analyst 1.6 TF software. Source operation parameters were as following: ion spray voltage, $-4500 \mathrm{~V}$; nebulizing gas, 60 psi; source temperature, $600^{\circ} \mathrm{C}$; drying gas, 70 psi; curtain gas, 35 psi. SA was quantified using PeakView based on the $[\mathrm{M}-\mathrm{H}]$ precursor $\mathrm{m} / \mathrm{z}$ of $137.024 \pm 0.02 \mathrm{Da}$ and qualified via an authentic standard.

\section{Transient protein expression, immunodetection and live cell imaging}

Plate-grown bacteria (Agrobacterium strain GV3101 pMP90 or pMP90RK) were resuspended in Agro Infiltration Medium (AIM; $10 \mathrm{mM} \mathrm{MES} \mathrm{pH} \mathrm{5.8,} 10 \mathrm{mM} \mathrm{MgCl}$ ) and infiltrated with a needless syringe at $\mathrm{OD}_{600}=0.6$ per strain. Cell death-based assays in $\mathrm{Nb}$ were repeated at least five times for evaluation of phenotypes, and detection of expressed fusion proteins was conducted for at least two replicates. For UV light documentation, $\mathrm{Nb}$ leaves were photographed on a gel documentation system (Alphalmager ${ }^{\circledR}$ ) using 5 s exposure time (aperture 2.0). Image adjustments were applied to full images. Trypan Blue staining was done as previously described (Stuttmann et al., 2011). For incubation of $\mathrm{Nb}$ plants in the dark after infiltration, whole plants were placed in a growth cabinet $\left(24 / 20^{\circ} \mathrm{C}, 16 \mathrm{~h} / 8 \mathrm{~h}, 60\right.$ $\% \mathrm{RH}$ ) without illumination for $2 \mathrm{~d}$, and cell death was documented $5 \mathrm{dpi}$. Samples for immunodetection of fusion proteins were taken $3 \mathrm{dpi}$. Leaf discs were ground in liquid nitrogen, leaf powder resuspended in Laemmli buffer and proteins denatured by boiling. Total protein extracts were separated by SDSPAGE and blotted on nitrocellulose membranes. Primary antibodies were $\alpha$-GFP (mouse) and $\alpha-H A$ (rat; both from Roche), $\alpha$-EDS1 (Rabbit) and horseradish peroxidase-coupled (GE Healthcare) or alkaline phosphatase-coupled (Sigma-Aldrich) secondary antibodies were used. A Zeiss LSM780 confocal laser scanning microscope was used for live cell imaging. All images are single planes.

\section{Plant transformation and genome editing}

Arabidopsis was transformed by floral dipping as previously described (Logemann et al., 2006), and primary transformants were either selected by resistance to phosphinotricin (BASTA) or seed 
bioRxiv preprint doi: https://doi.org/10.1101/2020.11.01.363895; this version posted November 2, 2020. The copyright holder for this preprint (which was not certified by peer review) is the author/funder, who has granted bioRxiv a license to display the preprint in perpetuity. It is made available under aCC-BY-ND 4.0 International license.

fluorescence (FAST; Shimada et al., 2010). Nb was transformed as previously described (dx.doi.org/10.17504/protocols.io.; Gantner et al., 2019), using previously described target sites / sgRNAs for NRG1 editing (Qi et al., 2018). Different versions of pDGE vectors (Ordon et al., 2017; Ordon et al., 2019; Barthel et al., 2020) were used to generate $d m 2$ and Nbnrg1 mutant lines by SpCas9. Respective target sites are provided in Figures S2 (Arabidopsis lines) and S3 (Nbnrg1). sgRNAs were prepared by cloning of hybridized oligonucleotides in PDGE shuttle vectors, as previously described (Ordon et al., 2017). Mutant lines were cured of the editing construct, with the exception of the dm2-11 line.

\section{Molecular cloning, genotyping and quantitative RT-PCR}

The GoldenGate strategy (Engler et al., 2008) was used for most clonings. Different DNA modules from the Modular Cloning system, the Plant Parts I and the Plant Parts II collections were used, and cut/ligation reactions employing either Bsal or Bpil together with T4 DNA Ligase (Thermo, 1-5 $\mathrm{u} / \mu \mathrm{l}$ ) were conducted using approximately $20 \mathrm{fmol}$ of each DNA module as previously described (Weber et al., 2011; Engler et al., 2014; Gantner et al., 2018). Additional plasmids were generated using Gateway cloning. In these cases, entry clones were generated by PCR (via TOPO cloning or GoldenGate cloning), and inserts were subsequently recombined into expression plasmids by LR reactions. Detailed information on plasmids used and/or generated in this study are provided in Table S3. A lab-internal Taq polymerase preparation was used for genotyping of different Arabidopsis lines. Genomic DNA was extracted by a CTAB protocol, and primer sequences are provided in Table S2. For transcript analyses, RNA was extracted by a TRIzol protocol, as previously described (Gantner et al., 2019). The Reverse Transcriptase Core Kit was used for cDNA synthesis, and the Takyon No ROX SYBR 2X MasterMix Blue dTTP qPCR Kit (both Eurogentech) for quantitative real-time PCR using a CFX96 detection system (BioRad). Transcript data was normalized to UBQ10; primer sequences are provided in Table S2.

\section{Figure Legends}

\section{Figure 1: $D M 2 h$ is the main locus targeted by the nde suppressor screen, and is sufficient for EDS1-YFPNLS-induced autoimmunity.}

a) Protein motifs, domain boundaries and mutations discovered in different $n d e$ alleles parsed onto the $D M 2 h$ gene model are shown (drawn to scale; gDM2h: $4031 \mathrm{nt} \mathrm{ATG->STOP).} \mathrm{A} \mathrm{total} \mathrm{of} 15$ LRRs is predicted for DM2h by LRRpredictor (Martin et al., 2020a).

b) $D M 2 a-g^{\text {Ler }}$ are not required for autoimmunity induced by EDS1-YFP ${ }^{\text {NLS }}$. Plants were grown under high temperature conditions, and shifted to $18 / 16^{\circ} \mathrm{C}$ to induce autoimmunity for $8 \mathrm{~d}$ prior to documentation. The NLS\#A3 line (parental line used for the nde suppressors screen) expresses EDS1YFP ${ }^{N L S}$ under EDS1 promoter control in the Col eds1-2 genetic background (a near isogenic line containing the $D M 2^{\text {Ler }}$ region). The $d m 2 h^{\text {nde1-1 }}$ allele was isolated from the suppressor screen, and was subsequently complemented by a T-DNA for expression of gDM2h under control of its own promoter $(+n p: D M 2 h)$. From a cross to Col, a line containing both transgenes (EDS1-YFP ${ }^{N L S}, D M 2 h$ ), but not the $D M 2^{\text {Ler }}$ region, was isolated. 
bioRxiv preprint doi: https//doi.org/10.1101/2020 11.01.363895; this version posted November 2, 2020. The copyright holder for this preprint (which was not certified by peer review) is the author/funder, who has granted bioRxiv a license to display the preprint in perpetuity. It is made available under aCC-BY-ND 4.0 International license.

c) PCR-genotyping of lines used in b), showing presence/absence of the two transgenes (EDS1-YFP NLS, $n p: D M 2 h$ ) and origin (Col, Ler) of the DM2 region.

\section{Figure 2: $d m 2$ mutant Arabidopsis lines used in this study}

Schematic drawing of the $D M 2^{\text {Ler }}$ region. Gene identifiers are the last three digits of At3g44xxx. Genes present in respective lines are depicted in black, and genes deleted or inactivated in mutant lines are shown in grey. Details on mutant lines are provided in Figure S2.

\section{Figure 3: Infection of $\mathrm{dm} 2$ mutant lines with bacterial and oomycete pathogens.}

a) Indicated plant lines were challenged with virulent Pst DC3000 bacteria, and bacterial titers determined at 0 and $3 \mathrm{dpi}$. Error bars indicate standard deviation of eight replicates, letters indicate statistically significant differences at day 3 as determined by one-way ANOVA and Fisher LSD ( $p<$ 0.001). The experiment was conducted three times with similar results; one representative experiment is shown.

b) Indicated plant lines were challenged with virulent $\mathrm{Hpa}$ isolate Cala2. Sporulation was assessed 7 dpi to quantify pathogen growth. The experiment was conducted four times with four replicates. Data was normalized by arbitrarily setting sporulation on Ler $=1$, and all 16 replicates were included in the analysis. Error bars and statistics as in a).

c) Infection phenotypes of indicated plant lines after challenge with $\mathrm{Hpa}$ isolate Emwa1, avirulent on Ler. First true leaves were stained with Trypan Blue $6 \mathrm{dpi}$. The experiment was conducted five times. Representative micrographs are shown. os - oospores, fh - free hyphae, hr - hypersensitive response, ehr - expanded $\mathrm{hr}$. Scale bar $=200 \mu \mathrm{m}$.

\section{Figure 4: $D M 2 h$ from the $D M 2^{\text {Ler }}$ cluster is sufficient for autoimmune induction by old3-1} or $S R F 3^{K o n d .}$

a) Contribution of $D M 2$ genes to old3-1-induced autoimmunity. Plants were grown for $7 \mathrm{~d}$ under short day conditions, shifted for $14 \mathrm{~d}$ to $28^{\circ} \mathrm{C}$, and then shifted to $18 / 16^{\circ} \mathrm{C}$. Phenotypes were documented $7 \mathrm{~d}$ after temperature shift.

b) Relative (Ler $\mathrm{Oh}=1$ ) salicylic acid $(\mathrm{SA})$ accumulation in leaf tissue of indicated plants lines at $28^{\circ} \mathrm{C}$ and $24 \mathrm{~h}$ after shift to $18 / 16^{\circ} \mathrm{C}$. The experiment was conducted twice (green and cyan data points, respectively) with four replicates per experiment. Letters indicate statistically significant differences (ANOVA, Tukey post-hoc test, $\mathrm{p}<0,001$ ).

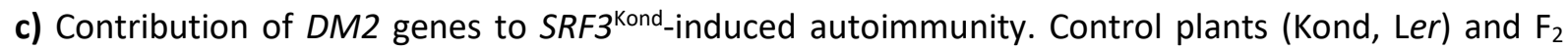
populations of the indicated crosses were grown under low temperature regime $\left(14^{\circ} \mathrm{C} / 12^{\circ} \mathrm{C}\right.$ day $/ \mathrm{night}$; short day). Representative plants were documented after seven weeks, and both wild type-like and autoimmune plants are shown for segregating populations. Crosses were verified by PCR genotyping (Figure S4). 
bioRxiv preprint doi: https://doi.org/10.1101/2020 11.01.363895; this version posted November 2, 2020. The copyright holder for this preprint (which was not certified by peer review) is the author/funder, who has granted bioRxiv a license to display the preprint in perpetuity. It is made available under aCC-BY-ND 4.0 International license.

d) Expression of the marker gene $P R 1$ in $\mathrm{F}_{2}$ plants from indicated crosses (to Kondara) as measured by quantitative RT-PCR. For crosses of Kond to Ler and $\Delta d m 2 a-g$, wt-like and autoimmune (AI) plants were analyzed. Means and standard errors of three biological replicates are shown. The experiment was conducted twice with similar results. Statistics as in b).

\section{Figure 5: Functional analysis of the DM2h receptor.}

a) Cell death induction by DM2 $\mathrm{h}_{1-279}$ and variants thereof in leaves of wild-type $N$. benthamiana. TIR domain fragments were expressed with a C-terminal GFP tag (35S:DM2h $\left.\mathrm{h}_{1-279}-\mathrm{GFP}\right)$, and plant reactions were documented 4 dpi.

b) Immunodetection and accumulation of proteins transiently expressed in a).

c) Cell death induction upon (co-) expression of DM2h or a DM2c/DM2h chimeric protein together with EDS1-YFP NLS or old3-1. After Agroinfiltration, plants were incubated in the dark for $2 \mathrm{~d}$, plant reactions were documented $5 \mathrm{dpi}$.

d) P-loop dependency of DM2h-mediated cell death. DM2h and P-loop variants, as indicated and without an epitope tag, were expressed by Agroinfiltration, and cell death induction was imaged $5 \mathrm{dpi}$. e) Immunodetection and accumulation of DM2h P-loop variants. Constructs similar to those used in d) but encoding an N-terminal 6xHA tag were used for Agroinfiltration. Protein extracts were prepared 3 dpi. Arrowheads mark two DM2h-specific signals. A non-specific signal, marked by an asterisk, is shown as loading control.

f) Subcellular localization of the DM2 $\mathrm{h}_{1-279}$ TIR domain fragment in $N$. benthamiana. GFP channel (upper panel) and a merged image (lower panel) including bright field and chlorophyll imaging (magenta) are shown. Similar results were obtained upon expression in Nbeds1. Scale bar $=20 \mu \mathrm{m}$.

g) Subcellular localization of a DM2h-YFP fusion protein in transgenic Arabidopsis (Col p35S:gDM2hYFP).14d old plants grown in short day conditions were used for imaging. With identical microscope settings, no fluorescence signal was detected in control plants. Multiple plants were analyzed; a representative micrograph is shown. Immunodetection of the DM2h-YFP fusion protein and growth phenotype of the transgenic line in Figure S5.

h) DM2h-mediated cell death induction is dependent on the TNL downstream signaling components EDS1 and NRG1. As in d), but different N. benthamiana mutant lines were used in co-expression assays. Details on the nrg1-4 mutant line in Figure S6.

\section{Figure 6: Activation of DM2h by EDS1-YFPNLS is independent of EDS1's role in signal transduction.}

a) Induction of HR-like cell death by different EDS1-YFP fusion protein variants in $N$. benthamiana. Indicated EDS1 variants were expressed together with DM2h, and cell death was imaged 6 dpi. Immunodetection of proteins and subcellular localization in Figure S7.

b) Induction of autoimmunity by EDS1-YFPNLS fusion protein variants. Transgenes for expression of immune-competent EDS1-YFP ${ }^{\text {NLS }}$ or the non-functional EDS1-YFP ${ }^{\text {NLS }}$ (F419A, L258A,L262A) variant under control of the native promoter were transformed into accession Ler or the Ler eds1-2 mutant line. Transgenic seeds were selected by FAST seed fluorescence. Plants were first grown four weeks under immune-suppressive conditions, and autoimmune induction was evaluated and documented $6 \mathrm{~d}$ 
bioRxiv preprint doi: https://doi org/10.1101/202011.01.363895; this version posted November 2, 2020. The copyright holder for this preprint (which was not certified by peer review) is the author/funder, who has granted bioRxiv a license to display the preprint in perpetuity. It is made available under aCC-BY-ND 4.0 International license.

after shift to $18 / 16^{\circ} \mathrm{C}$. Numbers indicate frequencies of autoimmune plants. Expression of transgenic proteins and presence/absence of endogenous EDS1 was shown on immunoblots (see Figure S7c).

Figure 7: Analysis of EDS1-YFPNLS properties required for activation of DM2h.

a) Schematic representation of different EDS1-YFP ${ }^{\text {NLS }}$ variants compared for their capacity to activate DM2h. Red box represents the Gateway linker (KGGRADPAFLYKVVDG), blue box an Ala-Ser-Ala (ASA) linker. Precise sequence of used NLSs is as follows: SV40 - PKKKRKV*; SV40(GG) - PKKKRKVGG*; c-myc - SAPAAKRVKLD*.

b) Induction of DM2h-mediated HR-like cell death by different EDS1-YFP ${ }^{N L S}$ variants in N. benthamiana co-expression assays. Plant reactions were imaged $5 \mathrm{dpi}$. Subcellular localization and accumulation of fusion proteins are shown in Figure $\mathrm{S} 8$.

c) Functionality of EDS1-YFP ${ }^{N L S}$ variants in TNL signaling. Indicated variants were transformed, under control of the native EDS1 promoter, into the Col eds1-2 line. Primary transformants were selected by FAST seed fluorescence. Plants were grown for $7 d$ under short day conditions and $10 \mathrm{~d}$ under high temperature conditions prior to infection with Hpa Cala2. First true leaves were Trypan Blue-stained 6 $\mathrm{dpi}$, and representative micrographs are shown. Numbers indicate plants with macroscopically visible sporulation. $\mathrm{hr}$ - hypersensitive response, fh - free hyphae. Scale bar $=200 \mu \mathrm{m}$.

d) Autoimmune induction by EDS1-YFP NLS variants. As in c), but plants were grown 7d under short day conditions, $20 \mathrm{~d}$ under high temperature conditions and were then shifted to low temperature $\left(18 / 16^{\circ} \mathrm{C}\right)$ for $5 \mathrm{~d}$, prior to documentation of autoimmune induction. Numbers indicate frequency of autoimmune plants among the total number of primary transformants that were analyzed. The experiment was performed twice. Frequencies for autoimmune plants were similar and total numbers from both replicates are indicated.

\section{Supporting Information}

Table S1: Molecular details on identified $d m 2 h / n d e 1$ alleles

Table S2: Oligonucleotides used in this study

Table S3: Plasmids used in this study

Supplemental Figure 1: Sequence alignment of TIR and NB -ARC domains

Supplemental Figure 2: $d m 2$ mutant lines used in this study

Supplemental Figure 3: Genotyping of hybrids obtained from crosses to accession Kondara

Supplemental Figure 4: A transient assay for reconstitution of DM2h activation in N. benthamiana based on protein co-expression and cell death induction

Supplemental Figure 5: Growth phenotype and immunoblot analysis of DM2h-YFP transgenic plants

Supplemental Figure 6: Molecular details on Nbnrg1 mutant lines generated in this study

Supplemental Figure 7: Immunodetection and subcellular localization of EDS1-YFP ${ }^{\text {NLS }}$ variants differing in immune signaling competency

Supplemental Figure 8: Immunodetection and subcellular localization of EDS1-YFP ${ }^{\text {NLS }}$ variants differing in NLS and linker sequences

Ordon et al, page | 18 
bioRxiv preprint doi: https://doi.org/10.1101/2020.11.01.363895; this version posted November 2, 2020. The copyright holder for this

\section{References}

Aarts, N., Metz, M., Holub, E., Staskawicz, B.J., Daniels, M.J., and Parker, J.E. (1998). Different requirements for EDS1 and NDR1 by disease resistance genes define at least two $R$ genemediated signaling pathways in Arabidopsis. Proceedings of the National Academy of Sciences of the United States of America 95, 10306-10311.

Alcazar, R., and Parker, J.E. (2011). The impact of temperature on balancing immune responsiveness and growth in Arabidopsis. Trends in plant science 16, 666-675.

Alcazar, R., Garcia, A.V., Parker, J.E., and Reymond, M. (2009). Incremental steps toward incompatibility revealed by Arabidopsis epistatic interactions modulating salicylic acid pathway activation. Proceedings of the National Academy of Sciences of the United States of America 106, 334-339.

Alcazar, R., Garcia, A.V., Kronholm, I., de Meaux, J., Koornneef, M., Parker, J.E., and Reymond, M. (2010). Natural variation at Strubbelig Receptor Kinase 3 drives immune-triggered incompatibilities between Arabidopsis thaliana accessions. Nat Genet 42, 1135-1139.

Alcazar, R., von Reth, M., Bautor, J., Chae, E., Weigel, D., Koornneef, M., and Parker, J.E. (2014). Analysis of a plant complex resistance gene locus underlying immune-related hybrid incompatibility and its occurrence in nature. PLoS Genet 10, e1004848.

Arora, D., Abel, N.B., Liu, C., Van Damme, P., Yperman, K., Eeckhout, D., Vu, L.D., Wang, J., Tornkvist, A., Impens, F., Korbei, B., Van Leene, J., Goossens, A., De Jaeger, G., Ott, T., Moschou, P.N., and Van Damme, D. (2020). Establishment of Proximity-dependent Biotinylation Approaches in Different Plant Model Systems. The Plant cell.

Atanasov, K.E., Liu, C., Erban, A., Kopka, J., Parker, J.E., and Alcazar, R. (2018). NLR Mutations Suppressing Immune Hybrid Incompatibility and Their Effects on Disease Resistance. Plant physiology 177, 1152-1169.

Balcke, G.U., Bennewitz, S., Bergau, N., Athmer, B., Henning, A., Majovsky, P., Jimenez-Gomez, J.M., Hoehenwarter, W., and Tissier, A. (2017). Multi-Omics of Tomato Glandular Trichomes Reveals Distinct Features of Central Carbon Metabolism Supporting High Productivity of Specialized Metabolites. The Plant cell 29, 960-983.

Barragan, C.A., Wu, R., Kim, S.T., Xi, W., Habring, A., Hagmann, J., Van de Weyer, A.L., Zaidem, M., Ho, W.W.H., Wang, G., Bezrukov, I., Weigel, D., and Chae, E. (2019). RPW8/HR repeats control NLR activation in Arabidopsis thaliana. PLoS Genet 15, e1008313.

Barthel, K., Martin, P., Ordon, J., Erickson, J.L., Gantner, J., Herr, R., Kretschmer, C., Berner, T., Keilwagen, J., Marillonnet, S., and Stuttmann, J. (2020). One-shot generation of duodecuple (12x) mutant Arabidopsis: Highly efficient routine editing in model species. bioRxiv, 2020.2003.2031.018671.

Bartsch, M., Gobbato, E., Bednarek, P., Debey, S., Schultze, J.L., Bautor, J., and Parker, J.E. (2006). Salicylic acid-independent ENHANCED DISEASE SUSCEPTIBILITY1 signaling in Arabidopsis immunity and cell death is regulated by the monooxygenase FMO1 and the Nudix hydrolase NUDT7. The Plant cell 18, 1038-1051.

Bentham, A., Burdett, H., Anderson, P.A., Williams, S.J., and Kobe, B. (2017). Animal NLRs provide structural insights into plant NLR function. Ann Bot 119, 827-702.

Bernoux, M., Burdett, H., Williams, S.J., Zhang, X., Chen, C., Newell, K., Lawrence, G.J., Kobe, B., Ellis, J.G., Anderson, P.A., and Dodds, P.N. (2016). Comparative Analysis of the Flax Immune Receptors L6 and L7 Suggests an Equilibrium-Based Switch Activation Model. The Plant cell 28, 146-159. 
bioRxiv preprint doi: https://doi.org/10.1101/2020.11.01.363895; this version posted November 2, 2020. The copyright holder for this preprint (which was not certified by peer review) is the author/funder, who has granted bioRxiv a license to display the preprint in perpetuity. It is made available under aCC-BY-ND 4.0 International license.

Bhattacharjee, S., Halane, M.K., Kim, S.H., and Gassmann, W. (2011). Pathogen effectors target Arabidopsis EDS1 and alter its interactions with immune regulators. Science (New York, N.Y 334, 1405-1408.

Bomblies, K., and Weigel, D. (2007). Hybrid necrosis: autoimmunity as a potential gene-flow barrier in plant species. Nat Rev Genet 8, 382-393.

Bomblies, K., Lempe, J., Epple, P., Warthmann, N., Lanz, C., Dangl, J.L., and Weigel, D. (2007). Autoimmune response as a mechanism for a Dobzhansky-Muller-type incompatibility syndrome in plants. PLoS biology $\mathbf{5}$, e236.

Bonardi, V., Tang, S., Stallmann, A., Roberts, M., Cherkis, K., and Dangl, J.L. (2011). Expanded functions for a family of plant intracellular immune receptors beyond specific recognition of pathogen effectors. Proceedings of the National Academy of Sciences of the United States of America 108, 16463-16468.

Botella, M.A., Parker, J.E., Frost, L.N., Bittner-Eddy, P.D., Beynon, J.L., Daniels, M.J., Holub, E.B., and Jones, J.D. (1998). Three genes of the Arabidopsis RPP1 complex resistance locus recognize distinct Peronospora parasitica avirulence determinants. The Plant cell 10, 18471860.

Branon, T.C., Bosch, J.A., Sanchez, A.D., Udeshi, N.D., Svinkina, T., Carr, S.A., Feldman, J.L., Perrimon, N., and Ting, A.Y. (2018). Efficient proximity labeling in living cells and organisms with TurbolD. Nature biotechnology 36, 880-887.

Burch-Smith, T.M., Schiff, M., Caplan, J.L., Tsao, J., Czymmek, K., and Dinesh-Kumar, S.P. (2007). A novel role for the TIR domain in association with pathogen-derived elicitors. PLoS biology 5 , e68.

Burdett, H., Bentham, A.R., Williams, S.J., Dodds, P.N., Anderson, P.A., Banfield, M.J., and Kobe, B. (2019). The Plant "Resistosome": Structural Insights into Immune Signaling. Cell Host Microbe 26, 193-201.

Castel, B., Ngou, P.M., Cevik, V., Redkar, A., Kim, D.S., Yang, Y., Ding, P., and Jones, J.D.G. (2018). Diverse NLR immune receptors activate defence via the RPW8-NLR NRG1. New Phytol.

Chae, E., Bomblies, K., Kim, S.T., Karelina, D., Zaidem, M., Ossowski, S., Martin-Pizarro, C., Laitinen, R.A., Rowan, B.A., Tenenboim, H., Lechner, S., Demar, M., Habring-Muller, A., Lanz, C., Ratsch, G., and Weigel, D. (2014). Species-wide genetic incompatibility analysis identifies immune genes as hot spots of deleterious epistasis. Cell 159, 1341-1351.

Chakraborty, J., Ghosh, P., and Das, S. (2018). Autoimmunity in plants. Planta 248, 751-767.

Chou, S., Krasileva, K.V., Holton, J.M., Steinbrenner, A.D., Alber, T., and Staskawicz, B.J. (2011). Hyaloperonospora arabidopsidis ATR1 effector is a repeat protein with distributed recognition surfaces. Proceedings of the National Academy of Sciences of the United States of America 108, 13323-13328.

Collier, S.M., Hamel, L.P., and Moffett, P. (2011). Cell death mediated by the N-terminal domains of a unique and highly conserved class of NB-LRR protein. Mol Plant Microbe Interact 24, 918931.

Cui, H., Tsuda, K., and Parker, J.E. (2015). Effector-triggered immunity: from pathogen perception to robust defense. Annu Rev Plant Biol 66, 487-511.

Dodds, P.N., and Rathjen, J.P. (2010). Plant immunity: towards an integrated view of plant-pathogen interactions. Nat Rev Genet 11, 539-548.

Duxbury, Z., Wang, S., MacKenzie, C.I., Tenthorey, J.L., Zhang, X., Huh, S.U., Hu, L., Hill, L., Ngou, P.M., Ding, P., Chen, J., Ma, Y., Guo, H., Castel, B., Moschou, P.N., Bernoux, M., Dodds, P.N., Vance, R.E., and Jones, J.D.G. (2020). Induced proximity of a TIR signaling domain on a plant-mammalian NLR chimera activates defense in plants. Proceedings of the National Academy of Sciences of the United States of America 117, 18832-18839.

Engler, C., Kandzia, R., and Marillonnet, S. (2008). A one pot, one step, precision cloning method with high throughput capability. PLoS ONE 3, e3647. 
bioRxiv preprint doi: https://doi.org/10.1101/2020.11.01.363895; this version posted November 2, 2020. The copyright holder for this preprint (which was not certified by peer review) is the author/funder, who has granted bioRxiv a license to display the preprint in perpetuity. It is made available under aCC-BY-ND 4.0 International license.

Engler, C., Youles, M., Gruetzner, R., Ehnert, T.M., Werner, S., Jones, J.D., Patron, N.J., and Marillonnet, S. (2014). A Golden Gate Modular Cloning Toolbox for Plants. ACS synthetic biology.

Gantner, J., Ordon, J., Kretschmer, C., Guerois, R., and Stuttmann, J. (2019). An EDS1-SAG101 Complex Is Essential for TNL-Mediated Immunity in Nicotiana benthamiana. The Plant cell 31, 2456-2474.

Gantner, J., Ordon, J., Ilse, T., Kretschmer, C., Gruetzner, R., Lofke, C., Dagdas, Y., Burstenbinder, K., Marillonnet, S., and Stuttmann, J. (2018). Peripheral infrastructure vectors and an extended set of plant parts for the Modular Cloning system. PLoS ONE 13, e0197185.

Goritschnig, S., Steinbrenner, A.D., Grunwald, D.J., and Staskawicz, B.J. (2016). Structurally distinct Arabidopsis thaliana NLR immune receptors recognize tandem WY domains of an oomycete effector. New Phytol 210, 984-996.

Holub, E.B., Beynon, J.L., and Crute, I.R. (1994). Phenotypic and genotypic characterization of interactions between isolates of peronospora parasitica and accessions of Arabidopsis thaliana. Molecular Plant-Microbe Interactions 7, 223-239.

Horsefield, S., Burdett, H., Zhang, X.X., Manik, M.K., Shi, Y., Chen, J., Qi, T.C., Gilley, J., Lai, J.S., Rank, M.X., Casey, L.W., Gu, W.X., Ericsson, D.J., Foley, G., Hughes, R.O., Bosanac, T., von Itzstein, M., Rathjen, J.P., Nanson, J.D., Boden, M., Dry, I.B., Williams, S.J., Staskawicz, B.J., Coleman, M.P., Ve, T., Dodds, P.N., and Kobe, B. (2019). NAD(+) cleavage activity by animal an plant TIR domains in cell death pathways. Science (New York, N.Y 365, 793-+.

Huh, S.U., Cevik, V., Ding, P., Duxbury, Z., Ma, Y., Tomlinson, L., Sarris, P.F., and Jones, J.D.G. (2017). Protein-protein interactions in the RPS4/RRS1 immune receptor complex. PLoS Pathog 13, e1006376.

Jacob, F., Vernaldi, S., and Maekawa, T. (2013). Evolution and Conservation of Plant NLR Functions. Front Immunol 4, 297.

Jiao, W.B., and Schneeberger, K. (2020). Chromosome-level assemblies of multiple Arabidopsis genomes reveal hotspots of rearrangements with altered evolutionary dynamics. Nat Commun 11, 989.

Jones, J.D., and Dangl, J.L. (2006). The plant immune system. Nature 444, 323-329.

Jubic, L.M., Saile, S., Furzer, O.J., El Kasmi, F., and Dangl, J.L. (2019). Help wanted: helper NLRs and plant immune responses. Current opinion in plant biology 50, 82-94.

Kim, S.H., Gao, F., Bhattacharjee, S., Adiasor, J.A., Nam, J.C., and Gassmann, W. (2010). The Arabidopsis Resistance-Like Gene SNC1 Is Activated by Mutations in SRFR1 and Contributes to Resistance to the Bacterial Effector AvrRps4. PLoS Pathogens 6.

Kim, W., Latrasse, D., Servet, C., and Zhou, D.X. (2013). Arabidopsis histone deacetylase HDA9 regulates flowering time through repression of AGL19. Biochemical and biophysical research communications 432, 394-398.

Kourelis, J., and van der Hoorn, R.A.L. (2018). Defended to the Nines: 25 Years of Resistance Gene Cloning Identifies Nine Mechanisms for R Protein Function. The Plant cell 30, 285-299.

Krasileva, K.V., Dahlbeck, D., and Staskawicz, B.J. (2010). Activation of an Arabidopsis resistance protein is specified by the in planta association of its leucine-rich repeat domain with the cognate oomycete effector. The Plant cell 22, 2444-2458.

Laflamme, B., Dillon, M.M., Martel, A., Almeida, R.N.D., Desveaux, D., and Guttman, D.S. (2020). The pan-genome effector-triggered immunity landscape of a host-pathogen interaction. Science (New York, N.Y 367, 763-768.

Lapin, D., Kovacova, V., Sun, X., Dongus, J.A., Bhandari, D.D., von Born, P., Bautor, J., Guarneri, N., Rzemieniewski, J., Stuttmann, J., Beyer, A., and Parker, J.E. (2019). A coevolved EDS1SAG101-NRG1 module mediates cell death signaling by TIR-domain immune receptors. The Plant cell.

Lee, R.R.Q., and Chae, E. (2020). Variation Patterns of NLR Clusters in Arabidopsis thaliana Genomes. Plant Communications 1. 
bioRxiv preprint doi: https://doi.org/10.1101/2020.11.01.363895; this version posted November 2, 2020. The copyright holder for this preprint (which was not certified by peer review) is the author/funder, who has granted bioRxiv a license to display the preprint in perpetuity. It is made available under aCC-BY-ND 4.0 International license.

Li, L., Habring, A., Wang, K., and Weigel, D. (2020). Atypical Resistance Protein RPW8/HR Triggers Oligomerization of the NLR Immune Receptor RPP7 and Autoimmunity. Cell Host Microbe 27, 405-417 e406.

Li, X., Clarke, J.D., Zhang, Y., and Dong, X. (2001). Activation of an EDS1-mediated R-gene pathway in the snc1 mutant leads to constitutive, NPR1-independent pathogen resistance. Molecular plant-microbe interactions : MPMI 14, 1131-1139.

Logemann, E., Birkenbihl, R.P., Ulker, B., and Somssich, I.E. (2006). An improved method for preparing Agrobacterium cells that simplifies the Arabidopsis transformation protocol. Plant methods 2, 16.

Luker, K.E., Smith, M.C., Luker, G.D., Gammon, S.T., Piwnica-Worms, H., and Piwnica-Worms, D. (2004). Kinetics of regulated protein-protein interactions revealed with firefly luciferase complementation imaging in cells and living animals. Proceedings of the National Academy of Sciences of the United States of America 101, 12288-12293.

Mair, A., Xu, S.L., Branon, T.C., Ting, A.Y., and Bergmann, D.C. (2019). Proximity labeling of protein complexes and cell-type-specific organellar proteomes in Arabidopsis enabled by TurbolD. Elife 8.

Martin, E.C., Sukarta, O.C.A., Spiridon, L., Grigore, L.G., Constantinescu, V., Tacutu, R., Goverse, A., and Petrescu, A.J. (2020a). LRRpredictor-A New LRR Motif Detection Method for Irregular Motifs of Plant NLR Proteins Using an Ensemble of Classifiers. Genes (Basel) 11.

Martin, R., Qi, T., Zhang, H., Liu, F., King, M., Toth, C., Nogales, E., and Staskawicz, B.J. (2020b). Structure of the activated Roq1 resistosome directly recognizing the pathogen effector XopQ. bioRxiv, 2020.2008.2013.246413.

Meyers, B.C., Kozik, A., Griego, A., Kuang, H., and Michelmore, R.W. (2003). Genome-wide analysis of NBS-LRR-encoding genes in Arabidopsis. The Plant cell 15, 809-834.

Muskett, P.R., Kahn, K., Austin, M.J., Moisan, L.J., Sadanandom, A., Shirasu, K., Jones, J.D.G., and Parker, J.E. (2002). Arabidopsis RAR1 exerts rate-limiting control of $R$ gene- mediated defenses against multiple pathogens. The Plant cell 14, 979-992.

Ngou, B.P.M., Ahn, H.-K., Ding, P., and Jones, J.D. (2020). Mutual Potentiation of Plant Immunity by Cell-surface and Intracellular Receptors. bioRxiv, 2020.2004.2010.034173.

Noël, L., Moores, T.L., van der Biezen, E.A., Parniske, M., Daniels, M.J., Parker, J.E., and Jones, J.D.G. (1999). Pronounced Intraspecific Haplotype Divergence at the RPP5 Complex Disease Resistance Locus of Arabidopsis. The Pant Cell 11, 2099-2111.

Ordon, J., Gantner, J., Kemna, J., Schwalgun, L., Reschke, M., Streubel, J., Boch, J., and Stuttmann, J. (2017). Generation of chromosomal deletions in dicotyledonous plants employing a userfriendly genome editing toolkit. Plant J 89, 155-168.

Ordon, J., Bressan, M., Kretschmer, C., Dall'Osto, L., Marillonnet, S., Bassi, R., Stuttmann, J.J.F., and Genomics, I. (2019). Optimized Cas9 expression systems for highly efficient Arabidopsis genome editing facilitate isolation of complex alleles in a single generation.

Park, H.J., Baek, D., Cha, J.Y., Liao, X., Kang, S.H., McClung, C.R., Lee, S.Y., Yun, D.J., and Kim, W.Y. (2019). HOS15 Interacts with the Histone Deacetylase HDA9 and the Evening Complex to Epigenetically Regulate the Floral Activator GIGANTEA. The Plant cell 31, 37-51.

Parker, J.E., Coleman, M.J., Szabo, V., Frost, L.N., Schmidt, R., van der Biezen, E.A., Moores, T., Dean, C., Daniels, M.J., and Jones, J.D. (1997). The Arabidopsis downy mildew resistance gene RPP5 shares similarity to the toll and interleukin-1 receptors with $\mathrm{N}$ and L6. The Plant cell 9, 879-894.

Prigozhin, D.M., and Krasileva, K.V. (2020). Intraspecies diversity reveals a subset of highly variable plant immune receptors and predicts their binding sites. bioRxiv, 2020.2007.2010.190785.

Qi, D., DeYoung, B.J., and Innes, R.W. (2012). Structure-function analysis of the coiled-coil and leucine-rich repeat domains of the RPS5 disease resistance protein. Plant physiology 158, 1819-1832.

Qi, T., Seong, K., Thomazella, D.P.T., Kim, J.R., Pham, J., Seo, E., Cho, M.J., Schultink, A., and Staskawicz, B.J. (2018). NRG1 functions downstream of EDS1 to regulate TIR-NLR-mediated 
bioRxiv preprint doi: https://doi.org/10.1101/2020.11.01.363895; this version posted November 2, 2020. The copyright holder for this preprint (which was not certified by peer review) is the author/funder, who has granted bioRxiv a license to display the preprint in perpetuity. It is made available under aCC-BY-ND 4.0 International license.

plant immunity in Nicotiana benthamiana. Proceedings of the National Academy of Sciences of the United States of America.

Rehmany, A.P., Gordon, A., Rose, L.E., Allen, R.L., Armstrong, M.R., Whisson, S.C., Kamoun, S., Tyler, B.M., Birch, P.R., and Beynon, J.L. (2005). Differential recognition of highly divergent downy mildew avirulence gene alleles by RPP1 resistance genes from two Arabidopsis lines. The Plant cell 17, 1839-1850.

Robert, X., and Gouet, P. (2014). Deciphering key features in protein structures with the new ENDscript server. Nucleic Acids Res 42, W320-324.

Rodriguez, E., El Ghoul, H., Mundy, J., and Petersen, M. (2016). Making sense of plant autoimmunity and 'negative regulators'. FEBS J 283, 1385-1391.

Saijo, Y., Loo, E.P., and Yasuda, S. (2018). Pattern recognition receptors and signaling in plantmicrobe interactions. Plant J 93, 592-613.

Saile, S.C., Jacob, P., Castel, B., Jubic, L.M., Salas-Gonzales, I., Backer, M., Jones, J.D.G., Dangl, J.L., and El Kasmi, F. (2020). Two unequally redundant "helper" immune receptor families mediate Arabidopsis thaliana intracellular "sensor" immune receptor functions. PLoS biology 18, e3000783.

Saur, I.M., Bauer, S., Kracher, B., Lu, X., Franzeskakis, L., Muller, M.C., Sabelleck, B., Kummel, F., Panstruga, R., Maekawa, T., and Schulze-Lefert, P. (2019). Multiple pairs of allelic MLA immune receptor-powdery mildew AVRA effectors argue for a direct recognition mechanism. Elife 8.

Schneeberger, K., Ossowski, S., Lanz, C., Juul, T., Petersen, A.H., Nielsen, K.L., Jorgensen, J.E., Weigel, D., and Andersen, S.U. (2009). SHOREmap: simultaneous mapping and mutation identification by deep sequencing. Nat Methods 6, 550-551.

Schreiber, K.J., Bentham, A., Williams, S.J., Kobe, B., and Staskawicz, B.J. (2016). Multiple Domain Associations within the Arabidopsis Immune Receptor RPP1 Regulate the Activation of Programmed Cell Death. PLoS Pathog 12, e1005769.

Shimada, T.L., Shimada, T., and Hara-Nishimura, I. (2010). A rapid and non-destructive screenable marker, FAST, for identifying transformed seeds of Arabidopsis thaliana. Plant J 61, 519-528.

Sinapidou, E., Williams, K., Nott, L., Bahkt, S., Tor, M., Crute, I., Bittner-Eddy, P., and Beynon, J. (2004). Two TIR:NB:LRR genes are required to specify resistance to Peronospora parasitica isolate Cala2 in Arabidopsis. Plant J 38, 898-909.

Song, W., Forderer, A., Yu, D., and Chai, J. (2020). Structural biology of plant defence. New Phytol.

Steinbrenner, A.D., Goritschnig, S., and Staskawicz, B.J. (2015). Recognition and activation domains contribute to allele-specific responses of an Arabidopsis NLR receptor to an oomycete effector protein. PLoS Pathog 11, e1004665.

Stuttmann, J., Hubberten, H.M., Rietz, S., Kaur, J., Muskett, P., Guerois, R., Bednarek, P., Hoefgen, R., and Parker, J.E. (2011). Perturbation of Arabidopsis amino acid metabolism causes incompatibility with the adapted biotrophic pathogen Hyaloperonospora arabidopsidis. The Plant cell 23, 2788-2803.

Stuttmann, J., Peine, N., Garcia, A.V., Wagner, C., Choudhury, S.R., Wang, Y., James, G.V., Griebel, T., Alcazar, R., Tsuda, K., Schneeberger, K., and Parker, J.E. (2016). Arabidopsis thaliana DM2h (R8) within the Landsberg RPP1-like Resistance Locus Underlies Three Different Cases of EDS1-Conditioned Autoimmunity. PLoS Genet 12, e1005990.

Tahir, J., Watanabe, M., Jing, H.C., Hunter, D.A., Tohge, T., Nunes-Nesi, A., Brotman, Y., Fernie, A.R., Hoefgen, R., and Dijkwel, P.P. (2013). Activation of R-mediated innate immunity and disease susceptibility is affected by mutations in a cytosolic $\mathrm{O}$-acetylserine (thiol) lyase in Arabidopsis. Plant J 73, 118-130.

Tran, D.T.N., Chung, E.H., Habring-Muller, A., Demar, M., Schwab, R., Dangl, J.L., Weigel, D., and Chae, E. (2017). Activation of a Plant NLR Complex through Heteromeric Association with an Autoimmune Risk Variant of Another NLR. Curr Biol 27, 1148-1160.

Van de Weyer, A.-L., Monteiro, F., Furzer, O.J., Nishimura, M.T., Cevik, V., Witek, K., Jones, J.D.G., Dangl, J.L., Weigel, D., and Bemm, F. (2019). The Arabidopsis thaliana pan-NLRome, 537001. 
bioRxiv preprint doi: https://doi.org/10.1101/2020.11.01.363895; this version posted November 2, 2020. The copyright holder for this preprint (which was not certified by peer review) is the author/funder, who has granted bioRxiv a license to display the preprint in perpetuity. It is made available under aCC-BY-ND 4.0 International license.

van Wersch, R., Li, X., and Zhang, Y. (2016). Mighty Dwarfs: Arabidopsis Autoimmune Mutants and Their Usages in Genetic Dissection of Plant Immunity. Front Plant Sci 7, 1717.

van Wersch, S., and Li, X. (2019). Stronger When Together: Clustering of Plant NLR Disease resistance Genes. Trends in plant science 24, 688-699.

Wagner, S., Stuttmann, J., Rietz, S., Guerois, R., Brunstein, E., Bautor, J., Niefind, K., and Parker, J.E. (2013). Structural basis for signaling by exclusive EDS1 heteromeric complexes with SAG101 or PAD4 in plant innate immunity. Cell Host Microbe 14, 619-630.

Wan, L., Essuman, K., Anderson, R.G., Sasaki, Y., Monteiro, F., Chung, E.H., Nishimura, E.O., DiAntonio, A., Milbrandt, J., Dangl, J.L., and Nishimura, M.T. (2019). TIR domains of plant immune receptors are $\mathrm{NAD}(+)$-cleaving enzymes that promote cell death. Science (New York, N.Y 365, 799-+.

Wang, J., Hu, M., Wang, J., Qi, J., Han, Z., Wang, G., Qi, Y., Wang, H.W., Zhou, J.M., and Chai, J. (2019a). Reconstitution and structure of a plant NLR resistosome conferring immunity. Science (New York, N.Y 364.

Wang, J., Wang, J., Hu, M., Wu, S., Qi, J., Wang, G., Han, Z., Qi, Y., Gao, N., Wang, H.W., Zhou, J.M., and Chai, J. (2019b). Ligand-triggered allosteric ADP release primes a plant NLR complex. Science (New York, N.Y 364.

Weber, E., Engler, C., Gruetzner, R., Werner, S., and Marillonnet, S. (2011). A modular cloning system for standardized assembly of multigene constructs. PLOS ONE 6, e16765.

Williams, S.J., Sohn, K.H., Wan, L., Bernoux, M., Sarris, P.F., Segonzac, C., Ve, T., Ma, Y., Saucet, S.B., Ericsson, D.J., Casey, L.W., Lonhienne, T., Winzor, D.J., Zhang, X., Coerdt, A., Parker, J.E., Dodds, P.N., Kobe, B., and Jones, J.D. (2014). Structural basis for assembly and function of a heterodimeric plant immune receptor. Science (New York, N.Y 344, 299-303.

Wirthmueller, L., Zhang, Y., Jones, J.D., and Parker, J.E. (2007). Nuclear accumulation of the Arabidopsis immune receptor RPS4 is necessary for triggering EDS1-dependent defense. Curr Biol 17, 2023-2029.

Wu, Z., Li, M., Dong, O.X., Xia, S., Liang, W., Bao, Y., Wasteneys, G., and Li, X. (2018). Differential regulation of TNL-mediated immune signaling by redundant helper CNLs. New Phytol.

Xu, F., Kapos, P., Cheng, Y.T., Li, M., Zhang, Y., and Li, X. (2014). NLR-associating transcription factor bHLH84 and its paralogs function redundantly in plant immunity. PLoS Pathog 10, e1004312.

Yang, L., Chen, X., Wang, Z., Sun, Q., Hong, A., Zhang, A., Zhong, X., and Hua, J. (2020). HOS15 and HDA9 negatively regulate immunity through histone deacetylation of intracellular immune receptor NLR genes in Arabidopsis. New Phytol 226, 507-522.

Yuan, M., Jiang, Z., Bi, G., Nomura, K., Liu, M., He, S.Y., Zhou, J.-M., and Xin, X.-F. (2020). Patternrecognition receptors are required for NLR-mediated plant immunity. bioRxiv, 2020.2004.2010.031294.

Zhang, X., Bernoux, M., Bentham, A.R., Newman, T.E., Ve, T., Casey, L.W., Raaymakers, T.M., Hu, J., Croll, T.I., Schreiber, K.J., Staskawicz, B.J., Anderson, P.A., Sohn, K.H., Williams, S.J., Dodds, P.N., and Kobe, B. (2017). Multiple functional self-association interfaces in plant TIR domains. Proceedings of the National Academy of Sciences of the United States of America 114, E2046-E2052. 
bioRxiv preprint doi: https://doi.org/10.1101/2020.11.01.363895; this version posted November 2, 2020. The copyright holder for this preprint (which was not certified by peer review) is the author/funder, who has granted bioRxiv a license to display the preprint in perpetuity. It is made available under aCC-BY-ND 4.0 International license.

\section{Figure 1 Ordon et al.}

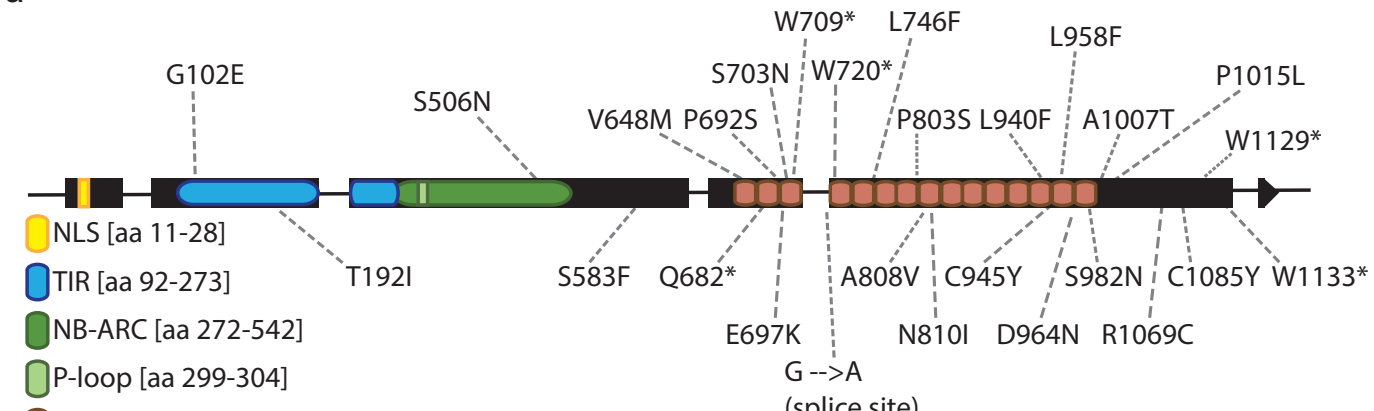

OLRRs [aa 628-1020]

b

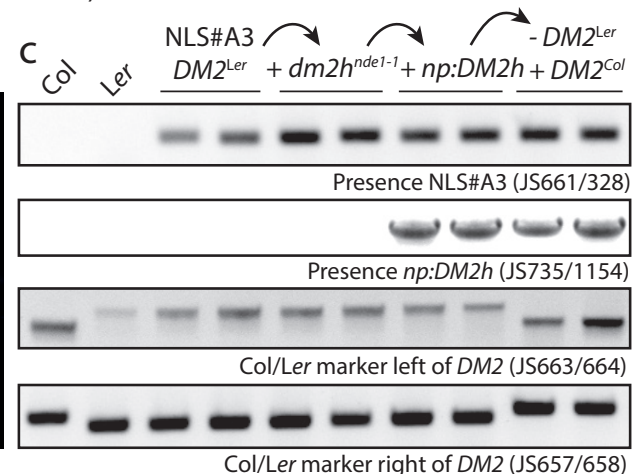

Figure 1: DM2h is the main locus targeted by the nde suppressor screen, and is sufficient for EDS1-YFP ${ }^{\text {NLS }}$-induced autoimmunity

a) Protein motifs, domain boundaries and mutations discovered in different nde alleles parsed onto the $D M 2 h$ gene model are shown (drawn to scale; gDM2h: 4031 nt ATG->STOP). A total of 15 LRRs is predicted for DM2h by LRRpredictor (Martin et al., 2020a).

b) DM2a-gLer are not required for autoimmunity induced by EDS1-YFPNLS. Plants were grown under high temperature conditions, and shifted to $18 / 16^{\circ} \mathrm{C}$ to induce autoimmunity for $8 \mathrm{~d}$ prior to documentation. The NLS\#A3 line (parental line used for the nde suppressors screen) expresses EDS1-YFPNLS under EDS1 promoter control in the Col eds1-2 genetic background (a near isogenic line containing the $D M 2^{\text {Ler }}$ region). The $d m 2 h^{\text {nder-1 }}$ allele was isolated from the suppressor screen, and was subsequently complemented by a T-DNA for expression of gDM $2 h$ under control of its own promoter (+ $n p: D M 2 h)$. From a cross to Col, a line containing both transgenes (EDS1-YFPNLS, DM2h), but not the DM2 ${ }^{\text {Ler }}$ region, was isolated.

c) PCR-genotyping of lines used in b), showing presence/absence of the two transgenes (EDS1-YFPNLS, np:DM2h) and origin (Col, Ler) of the DM2 region. 
Figure 2 Ordon et al.

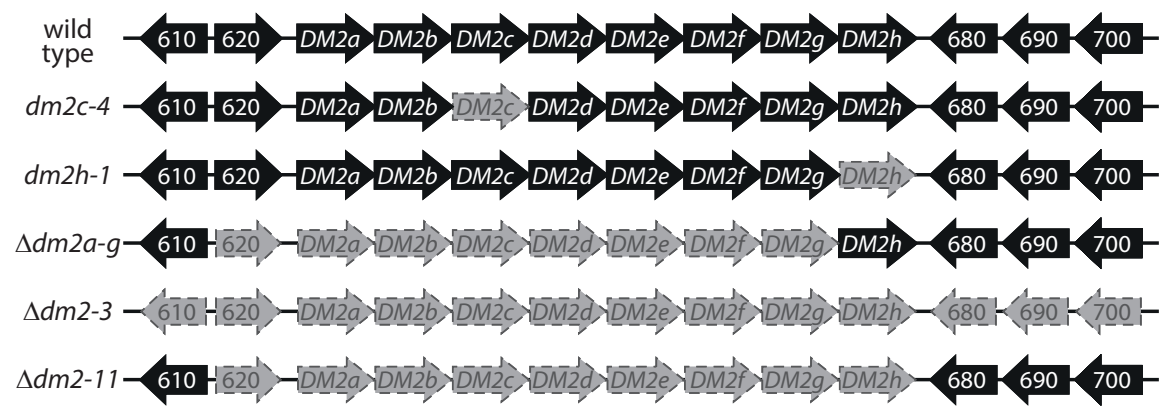

Figure 2: $d m 2$ mutant Arabidopsis lines used in this study

Schematic drawing of the $D M 2^{\text {Ler }}$ region. Gene identifiers are the last three digits of At3g44xxx. Genes present in respective lines are depicted in black, and genes deleted or inactivated in mutant lines are shown in grey. Details on mutant lines are provided in Figure S2. 


\section{Figure 3 Ordon et al.}
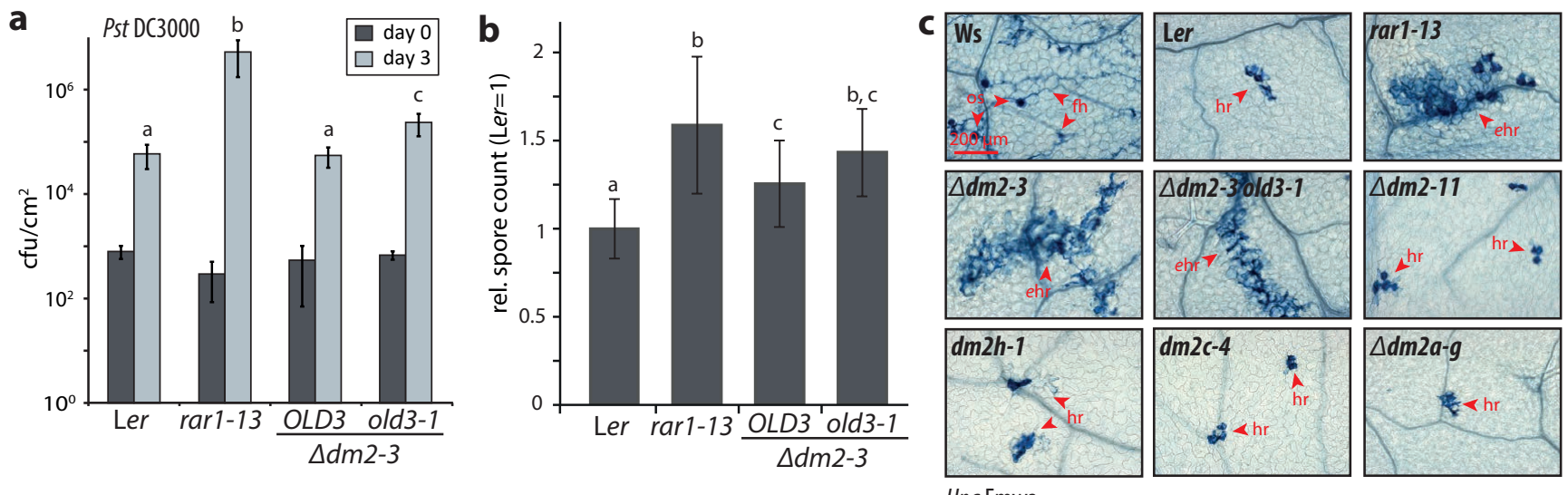

Hpa Emwa

Figure 3: Infection of $d m 2$ mutant lines with bacterial and oomycete pathogens.

a) Indicated plant lines were challenged with virulent Pst DC3000 bacteria, and bacterial titers determined at 0 and 3 dpi. Error bars indicate standard deviation of eight replicates, letters indicate statistically significant differences at day 3 as determined by one-way ANOVA and Fisher LSD ( $p<0.001)$. The experiment was conducted three times with similar results; one representative experiment is shown.

b) Indicated plant lines were challenged with virulent $\mathrm{Hpa}$ isolate Cala2. Sporulation was assessed $7 \mathrm{dpi}$ to quantify pathogen growth. The experiment was conducted four times with four replicates. Data was normalized by arbitrarily setting sporulation on Ler $=1$, and all 16 replicates were included in the analysis. Error bars and statistics as in a).

c) Infection phenotypes of indicated plant lines after challenge with Hpa isolate Emwa1, avirulent on Ler. First true leaves were stained with Trypan Blue $6 \mathrm{dpi}$. The experiment was conducted five times. Representative micrographs are shown. os - oospores, fh - free hyphae, hr - hypersensitive response, ehr - expanded hr. Scale bar $=200 \mu \mathrm{m}$. 


\section{Figure 4 Ordon et al.}

a
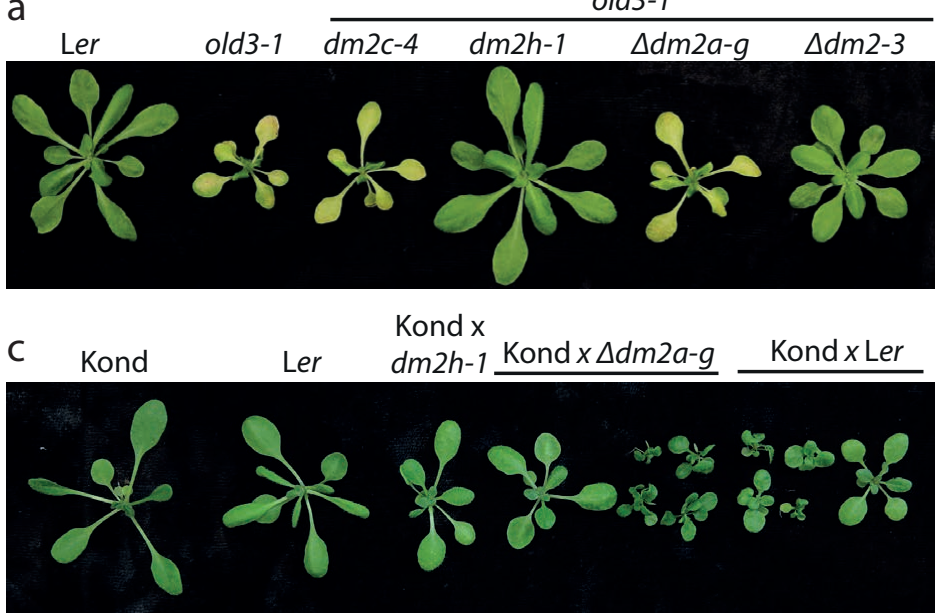

b

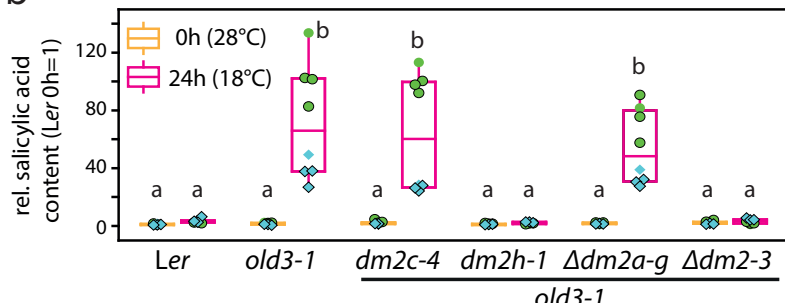

d

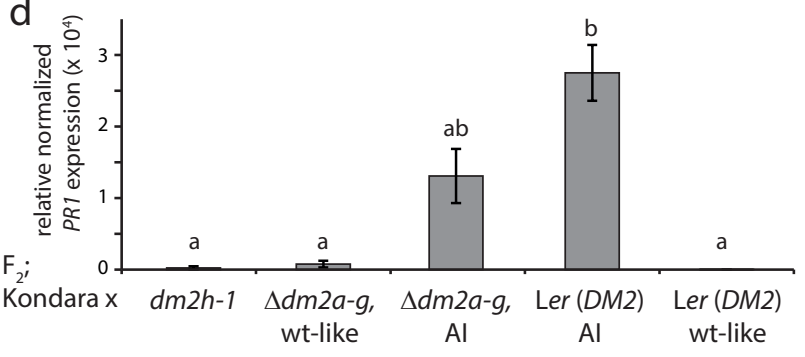

Figure 4: $D M 2 h$ from the $D M 2^{\text {Ler }}$ cluster is sufficient for autoimmune induction by old3-1 or SRF3 $3^{\text {Kond }}$.

a) Contribution of DM2 genes to old3-1-induced autoimmunity. Plants were grown for 7d under short day conditions, shifted for $14 \mathrm{~d}$ to $28^{\circ} \mathrm{C}$, and then shifted to $18 / 16^{\circ} \mathrm{C}$. Phenotypes were documented $7 \mathrm{~d}$ after temperature shift.

b) Relative ( $\mathrm{Ler} \mathrm{Oh}=1$ ) salicylic acid $(\mathrm{SA})$ accumulation in leaf tissue of indicated plants lines at $28^{\circ} \mathrm{C}$ and $24 \mathrm{~h}$ after shift to $18 / 16^{\circ} \mathrm{C}$. The experiment was conducted twice (green and cyan data points, respectively) with four replicates per experiment. Letters indicate statistically significant differences (ANOVA, Tukey post-hoc test, $p<0,001$ ).

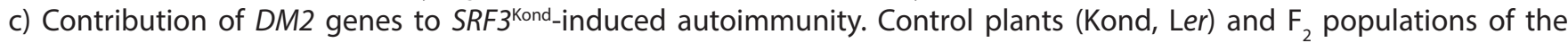
indicated crosses were grown under low temperature regime $\left(14^{\circ} \mathrm{C} / 12^{\circ} \mathrm{C}\right.$ day/night; short day). Representative plants were documented after seven weeks, and both wild type-like and autoimmune plants are shown for segregating populations. Crosses were verified by PCR genotyping (Figure S3).

d) Expression of the marker gene $P R 1$ in $\mathrm{F}_{2}$ plants from indicated crosses (to Kondara) as measured by quantitative RT-PCR. For crosses of Kond to Ler and $\Delta d m 2 a-g$, wt-like and autoimmune (Al) plants were analyzed. Means and standard errors of three biological replicates are shown. The experiment was conducted twice with similar results. Statistics as in b). 
bioRxiv preprint doi: https://doi.org/10.1101/2020.11.01.363895; this version posted November 2, 2020. The copyright holder for this preprint (which was not certified by peer review) is the author/funder, who has granted bioRxiv a license to display the preprint in perpetuity. It is made available under aCC-BY-ND 4.0 International license.

\section{Figure 5 Ordon et al.}
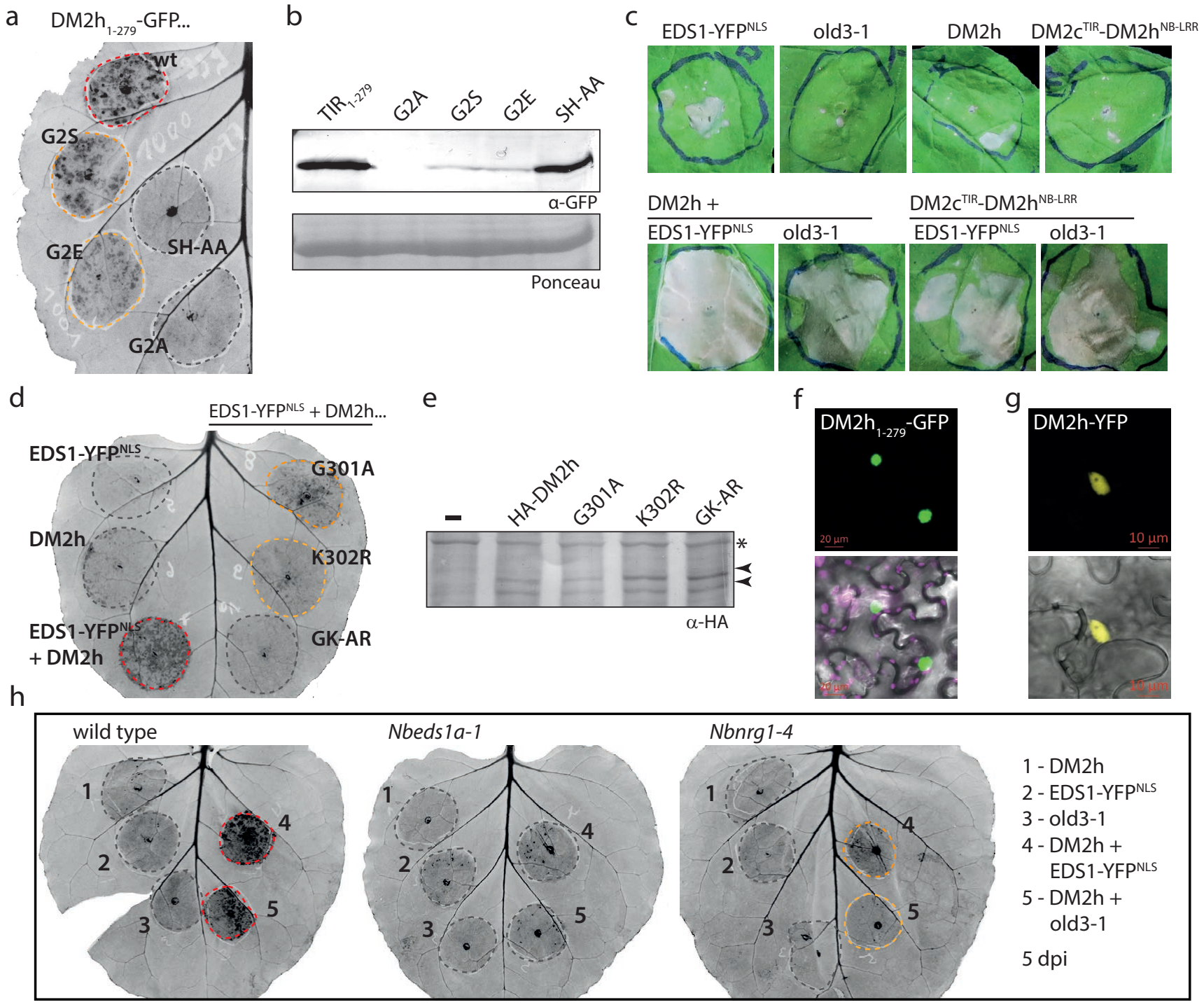

Figure 5: Functional analysis of the DM2h receptor.

a) Cell death induction by DM2 $\mathrm{h}_{1-279}$ and variants thereof in leaves of wild-type $N$. benthamiana. TIR domain fragments were expressed with a C-terminal GFP tag (35S:DM2h $\left.h_{1-279}-G F P\right)$, and plant reactions were documented $4 \mathrm{dpi}$.

b) Immunodetection and accumulation of proteins transiently expressed in a).

c) Cell death induction upon (co-) expression of DM2h or a DM2c/DM2h chimeric protein together with EDS1-YFPNLS or old3-1. After Agroinfiltration, plants were incubated in the dark for 2d, plant reactions were documented $5 \mathrm{dpi}$.

d) P-loop dependency of DM2h-mediated cell death. DM2h and P-loop variants, as indicated and without an epitope tag, were expressed by Agroinfiltration, and cell death induction was imaged $5 \mathrm{dpi}$.

e) Immunodetection and accumulation of DM2h P-loop variants. Constructs similar to those used in d) but encoding an $\mathrm{N}$-terminal $6 \mathrm{xHA}$ tag were used for Agroinfiltration. Protein extracts were prepared $3 \mathrm{dpi}$. Arrowheads mark two DM2h-specific signals. A non-specific signal, marked by an asterisk, is shown as loading control.

f) Subcellular localization of the DM2 $\mathrm{h}_{1-279}$ TIR domain fragment in N. benthamiana. GFP channel (upper panel) and a merged image (lower panel) including bright field and chlorophyll imaging (magenta) are shown. Similar results were obtained upon expression in Nbeds1. Scale bar $=20 \mu \mathrm{m}$.

g) Subcellular localization of a DM2h-YFP fusion protein in transgenic Arabidopsis (Col p35S:DM2h-YFP).14d old plants grown in short day conditions were used for imaging. With identical microscope settings, no fluorescence signal was detected in control plants. Multiple plants were analyzed; a representative micrograph is shown. Immunodetection of the DM2h-YFP fusion protein and growth phenotype of the transgenic line in Figure S5.

h) DM2h-mediated cell death induction is dependent on the TNL downstream signaling components EDS1 and NRG1. As in d), but different $N$. benthamiana mutant lines were used in co-expression assays. Details on the $n r g 1-4$ mutant line in Figure S6. 
bioRxiv preprint doi: https://doi.org/10.1101/2020.11.01.363895; this version posted November 2, 2020. The copyright holder for this preprint (which was not certified by peer review) is the author/funder, who has granted bioRxiv a license to display the preprint in perpetuity. It is made available under aCC-BY-ND 4.0 International license.

\section{Figure 6 Ordon et al.}

a

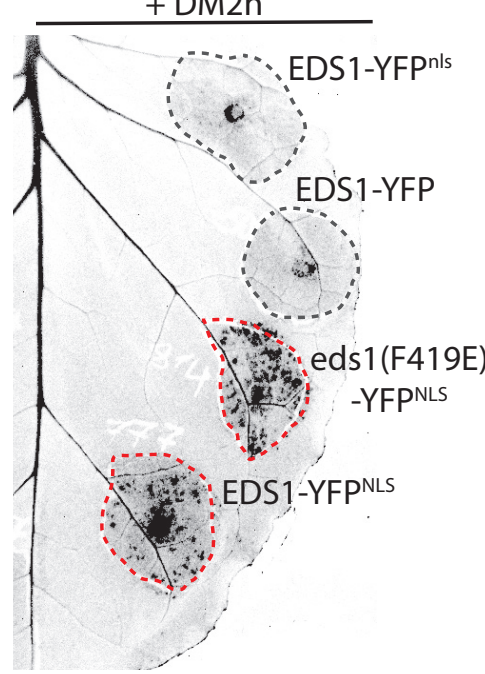

b

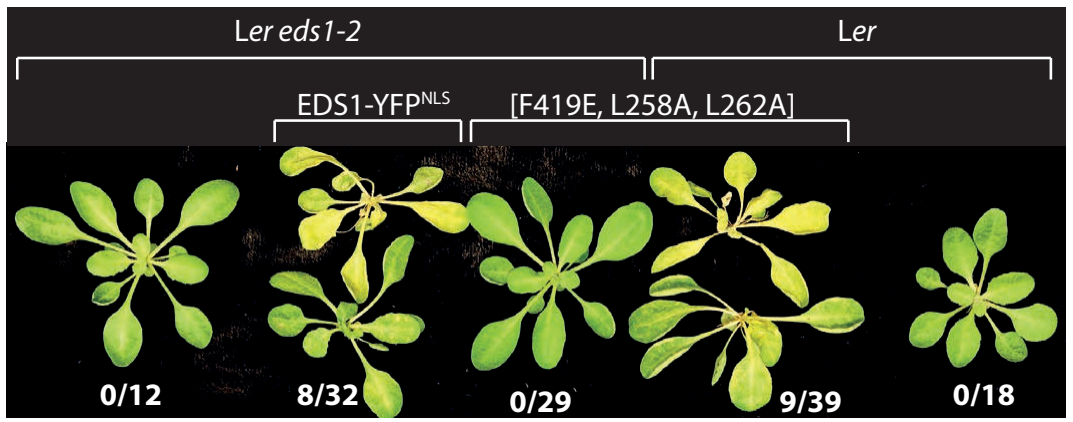

Figure 6: Activation of DM2h by EDS1-YFPNLS is independent of EDS1's role in signal transduction.

a) Induction of HR-like cell death by different EDS1-YFP fusion protein variants in N. benthamiana. Indicated EDS1 variants were expressed together with DM2h, and cell death was imaged $6 \mathrm{dpi}$. Immunodetection of proteins and subcellular localization in Figure S7.

b) Induction of autoimmunity by EDS1-YFPNLS fusion protein variants. Transgenes for expression of immune-competent EDS1-YFPNLS or the non-functional EDS1-YFPNLS(F419A, L258A,L262A) variant under control of the native promoter were transformed into accession Ler or the Ler eds 1-2 mutant line. Transgenic seeds were selected by FAST seed fluorescence. Plants were first grown four weeks under immune-suppressive conditions, and autoimmune induction was evaluated and documented $6 \mathrm{~d}$ after shift to $18 / 16^{\circ} \mathrm{C}$. Numbers indicate frequencies of autoimmune plants. Expression of transgenic proteins and presence/absence of endogenous EDS1 was shown on immunoblots (see Figure S7c). 
bioRxiv preprint doi: https://doi.org/10.1101/2020.11.01.363895; this version posted November 2, 2020. The copyright holder for this preprint (which was not certified by peer review) is the author/funder, who has granted bioRxiv a license to display the preprint in perpetuity. It is made available under aCC-BY-ND 4.0 International license.

\section{Figure 7 Ordon et al.}

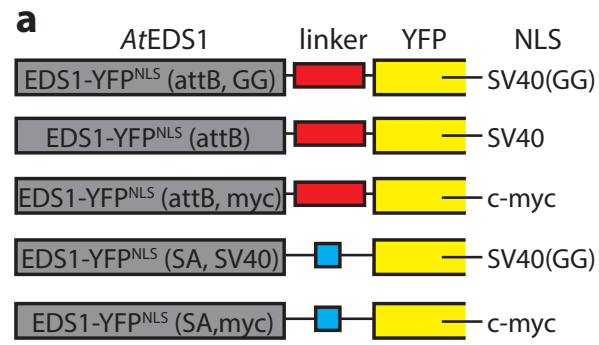

c

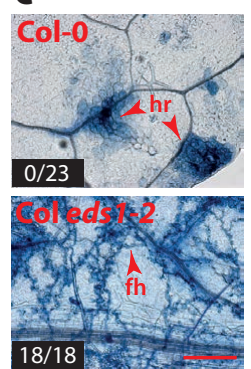

eds1-2 np:EDS1-YFPNLS

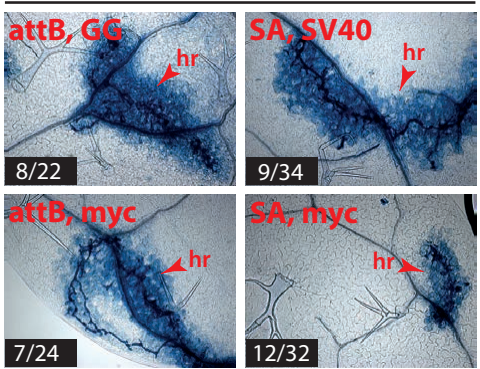

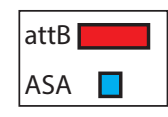

b

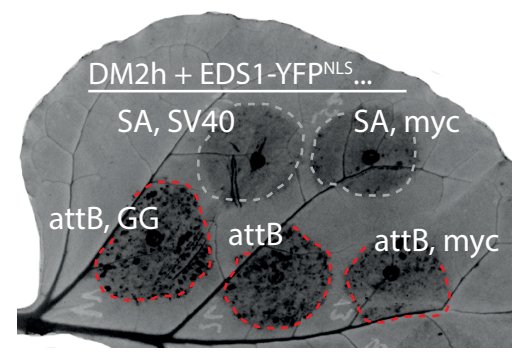

d

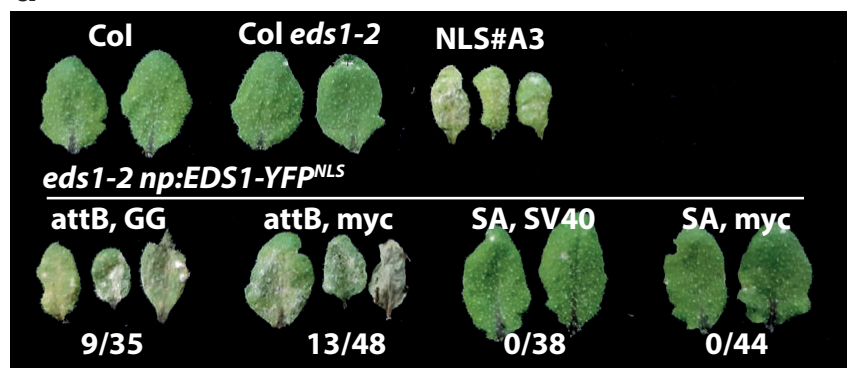

Figure 7: Analysis of EDS1-YFPNLS properties required for activation of DM2h.

a) Schematic representation of different EDS1-YFP NLS variants compared for their capacity to activate DM2h. Red box represents the Gateway linker (KGGRADPAFLYKVVDG), blue box an Ala-Ser-Ala (ASA) linker. Precise sequence of used NLSs is as follows: SV40 - PKKKRKV*; SV40(GG) - PKKKRKVGG*; c-myc - SAPAAKRVKLD*.

b) Induction of DM2h-mediated HR-like cell death by different EDS1-YFPNLS variants in N. benthamiana co-expression assays. Plant reactions were imaged $5 \mathrm{dpi}$. Subcellular localization and accumulation of fusion proteins are shown in Figure 58 .

c) Functionality of EDS1-YFPNLS variants in TNL signaling. Indicated variants were transformed, under control of the native EDS1 promoter, into the Col eds 1-2 line. Primary transformants were selected by FAST seed fluorescence. Plants were grown for $7 \mathrm{~d}$ under short day conditions and $10 \mathrm{~d}$ under high temperature conditions prior to infection with Hpa Cala2. First true leaves were Trypan Blue-stained $6 \mathrm{dpi}$, and representative micrographs are shown. Numbers indicate plants with macroscopically visible sporulation. $\mathrm{hr}$ - hypersensitive response, fh - free hyphae. Scale bar $=200 \mu \mathrm{m}$.

d) Autoimmune induction by EDS1-YFPNLS variants. As in c), but plants were grown 7d under short day conditions, 20d under high temperature conditions and were then shifted to low temperature $\left(18 / 16^{\circ} \mathrm{C}\right)$ for $5 \mathrm{~d}$, prior to documentation of autoimmune induction. Numbers indicate frequency of autoimmune plants among the total number of primary transformants that were analyzed. The experiment was performed twice. Frequencies for autoimmune plants were similar and total numbers from both replicates are indicated. 
bioRxiv preprint doi: https://doi.org/10.1101/2020.11.01.363895; this version posted November 2, 2020. The copyright holder for this

preprint (which was not certified by peer review) is the author/funder, who has granted bioRxiv a license to display the preprint in perpetuity. It is made available under aCC-BY-ND 4.0 International license.

\section{Supplemental Figure 1 Ordon et al.}

At-RPS4
At-DM2h (Ler)
At-RPS6
Ng-N
At-VICTR
At-SNC1
Nb-Roq1

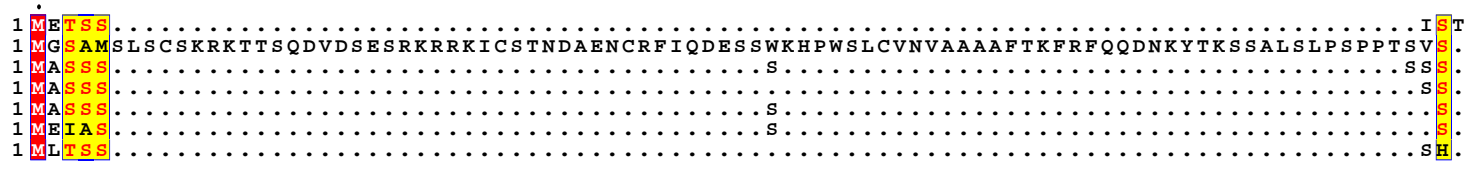

At-RPS4

At-DM2h (Ler)

At-RPS
Ng-N

Ng-N

At-VICTR

Nb-Rogl

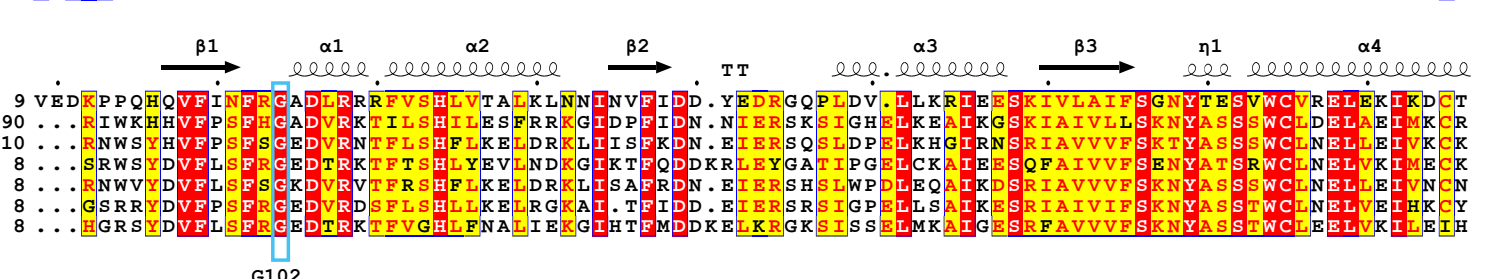
G102

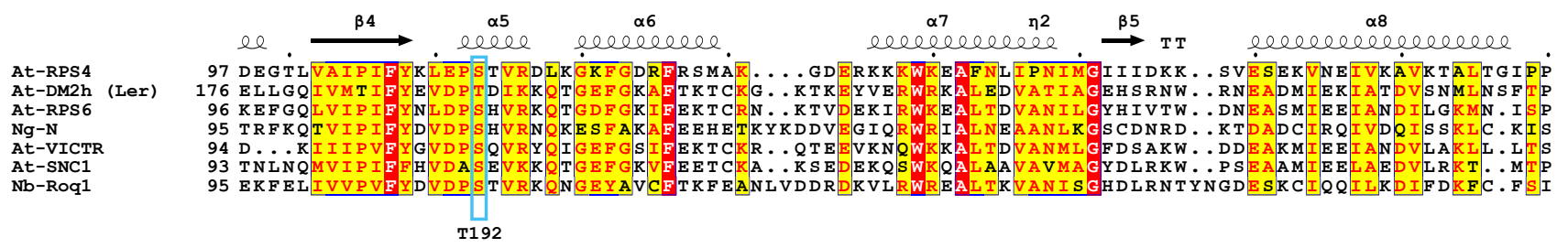

At-RPS4
At-DM2h (Ler)
At-RPS6
Ng-N
At-VICTR
At-SNC1
Nb-Roq1
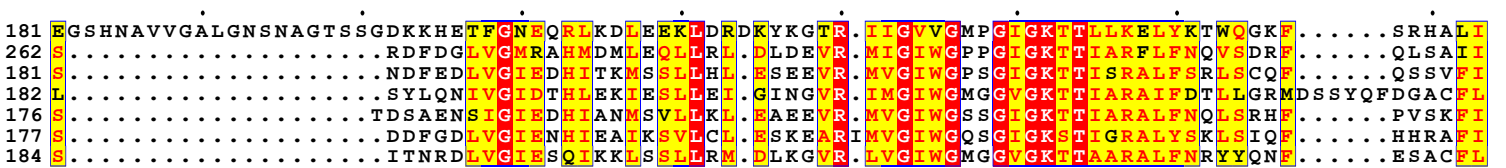

$\mathrm{Ng}-\mathrm{N}$

At-VICTR

At-SNC1
Nb-Roq1

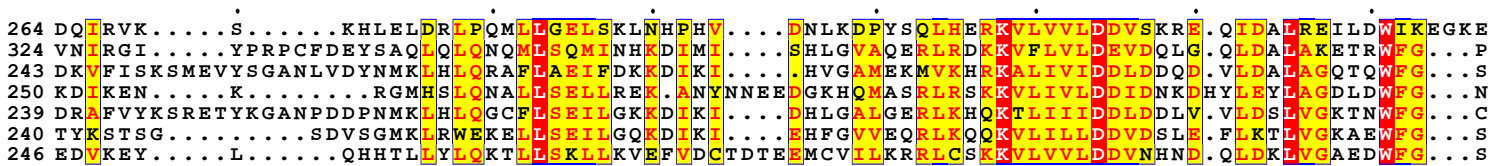

At-RPS 4

At-DM2h (Le

At-RPS

$\mathrm{Ng}-\mathrm{N}$

At-VICTR

At-SNC1
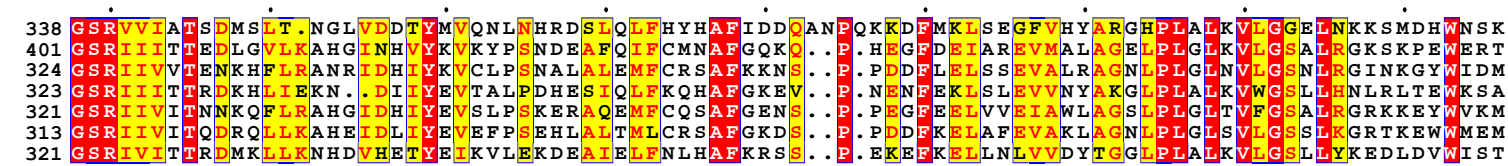

At-RPS4

$\begin{array}{ll}\text { At-RPS4 } & \\ \text { At-DM2h (Ler) } \\ \text { At-RPS6 }\end{array}$

$\mathrm{Ng}-\mathrm{N}$

At-VICTR

At-SNC1
Nb-Rog1

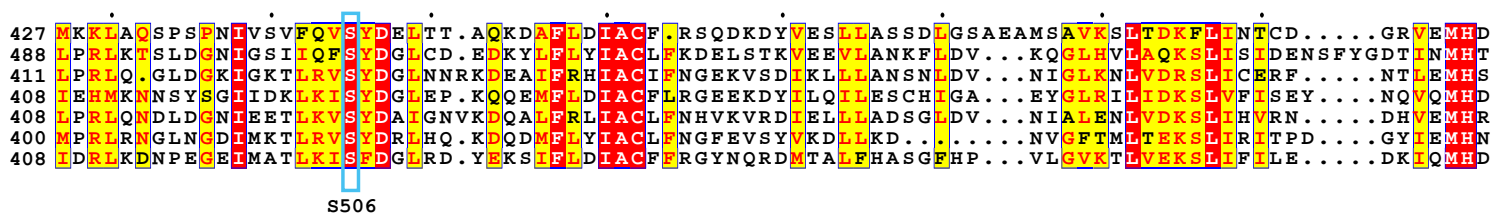

Supplemental Figure 1: Sequence alignment of TIR and NB -ARC domains

Indicated proteins were aligned using tcoffee, and the alignment was rendered using ESPript. Secondary structure elements of the Arabidopsis RPS4 TIR domain (PDB:4C6R) are shown above the alignment. Positions / amino acids affected by nde mutations are boxed. At - Arabidopsis thaliana, $\mathrm{Ng}$ - Nicotiana glutinosa, $\mathrm{Nb}$ - Nicotiana benthamiana. UniProt identifiers: AtRPS4 - Q9XGM3, AtRPS6 - P0DKH6, NgN - Q40392, AtVICTR - F4KHI3, AtSNC1 - O23530, NbRoq1 A0A290U7C4. 
bioRxiv preprint doi: https://doi.org/10.1101/2020.11.01.363895; this version posted November $2,2020$. The copyright holder for this preprint (which was not certified by peer review) is the author/funder, who has granted bioRxiv a license to display the preprint in perpetuity. It is made available under aCC-BY-ND 4.0 International license.

\section{Supplemental Figure 2 Ordon et al.}

a

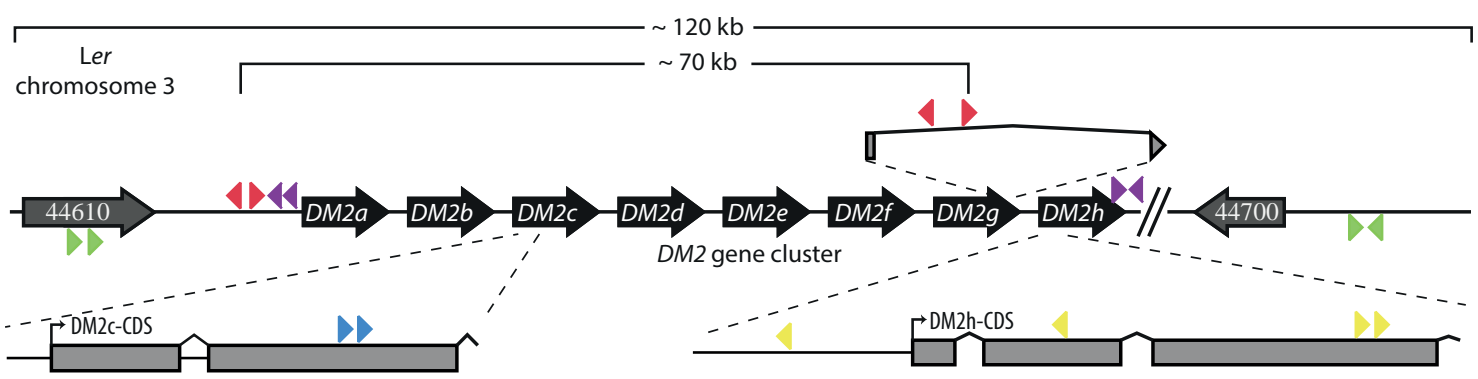

b PDGE4

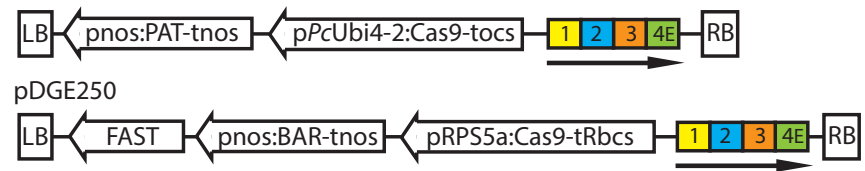

C

dm2c-4 $\gg$

1- CGgCTAAGCAATCTGATATG

2- TCCATTAGAATGGTGAAGGA

3- GGACAAAAGCACCCAAATGA

4- AGGGAAGTTACCTACCTTGC

in PDGE4

d

1- AAATCTCACCGATACATGAA

2- TGATTTCTGCTAATTCATCA

3- ATTATACAGTTCAGTTACGA

4- ATTATCAACCAAAGTGGAAG

in PDGE4 $d m 2 h-1 \quad$

\section{e}

\section{$\triangle d m 2 a-g$}

1- CGCGGCAGTTCGGTCCGCCA

2- GCCGACCTGCCGCCTAATTG

3- CACTGCAGAGATATTGAACG

4- GTTATATAATGCTTGATGGA

in PDGE4

\section{f}

$\Delta d m 2-3 \quad>$

1- GTTAgGTCCTACGCAgTAAC 1- TCAGATGATCGgaAATGAgA

2- CCACTGTTAGGCATGCATGA 2- GAGAAATTCTGGGTTTTGCT

3- TGCGCCTTCGGATTCTCGGG 3- ACATTGATTAATCATTGAGT

4- TAACCGTCGGCTCGGGTCCT 4- ACATTTGCAAGAAATATTAG

in PDGE4

\begin{abstract}
9
\end{abstract}
$\mathrm{h}$

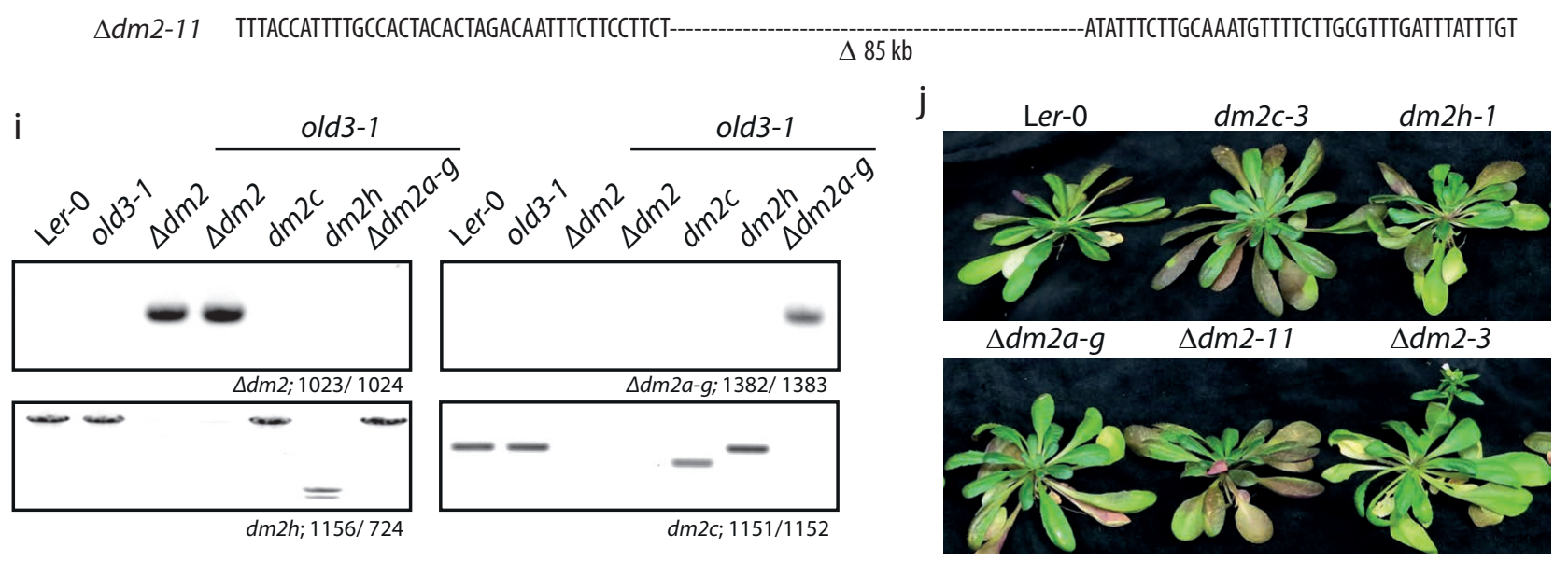

Supplemental Figure 2: $d m 2$ mutant lines used in this study.

a) Schematic drawing of the $D M 2^{\text {Ler }}$ region with sgRNA target sites (colored triangles) indicated.

b) Schematic drawing of constructs (T-DNA region) used for genome editing.

c) - g) Sites targeted by RNA-guided nucleases for generation of indicated mutant lines. Color code corresponds to panel a).

h) Precise lesions detected in $d m 2$ mutant lines used in this study.

i) Genotyping of $d m 2$ mutant lines.

j) Early flowering phenotype of $\Delta d m 2-3$ mutant plants. Plants were grown side-by-side for 7 - 8 weeks under short day conditions. Representative plants were selected for documentation. 


\section{Supplemental Figure 3 Ordon et al.}

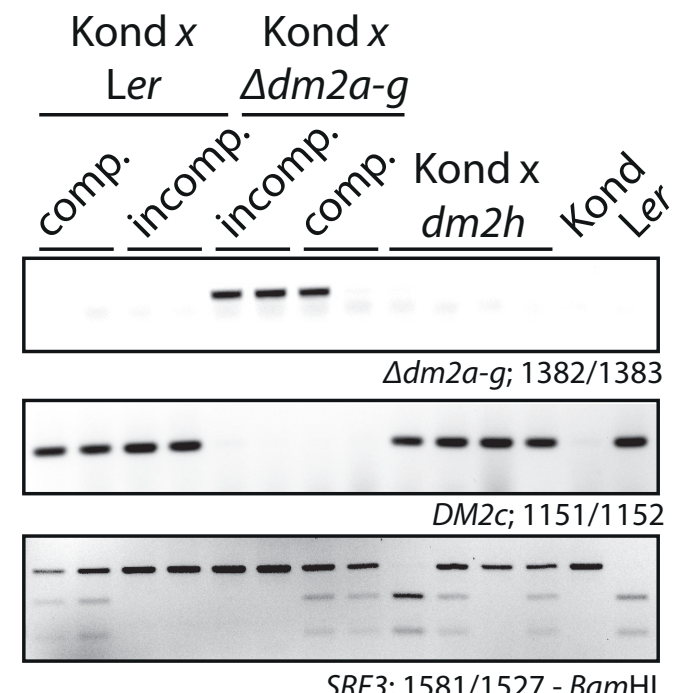

Supplemental Figure 3: Genotyping of hybrids obtained from crosses to accession Kondara.

Compatible (comp.) and incompatible (incomp.) hybrids obtained from $\mathrm{F}_{2}$ generations from crosses of Ler or dm2 mutant lines to Kondara, as shown in Figure 4, were genotyped by PCR. Primer combination 1382/1383 detects the $\Delta d m 2 a-g$ deletion. Primer combination 1151/1152 detects presence of DM2c, and was used to probe presence/absence of the DM2 cluster. A CAPS marker differentiating SRF3 from Ler and Kondara shows segregation of these alleles in compatible hybrids, while only the SRF3 ${ }^{\text {Kond }}$ allele was detected in incompatible hybrids, as expected. 
bioRxiv preprint doi: https://doi.org/10.1101/2020.11.01.363895; this version posted November 2,2020 . The copyright holder for this preprint (which was not certified by peer review) is the author/funder, who has granted bioRxiv a license to display the preprint in perpetuity. It is made available under aCC-BY-ND 4.0 International license.

\section{Supplemental Figure 4 Ordon et al.}
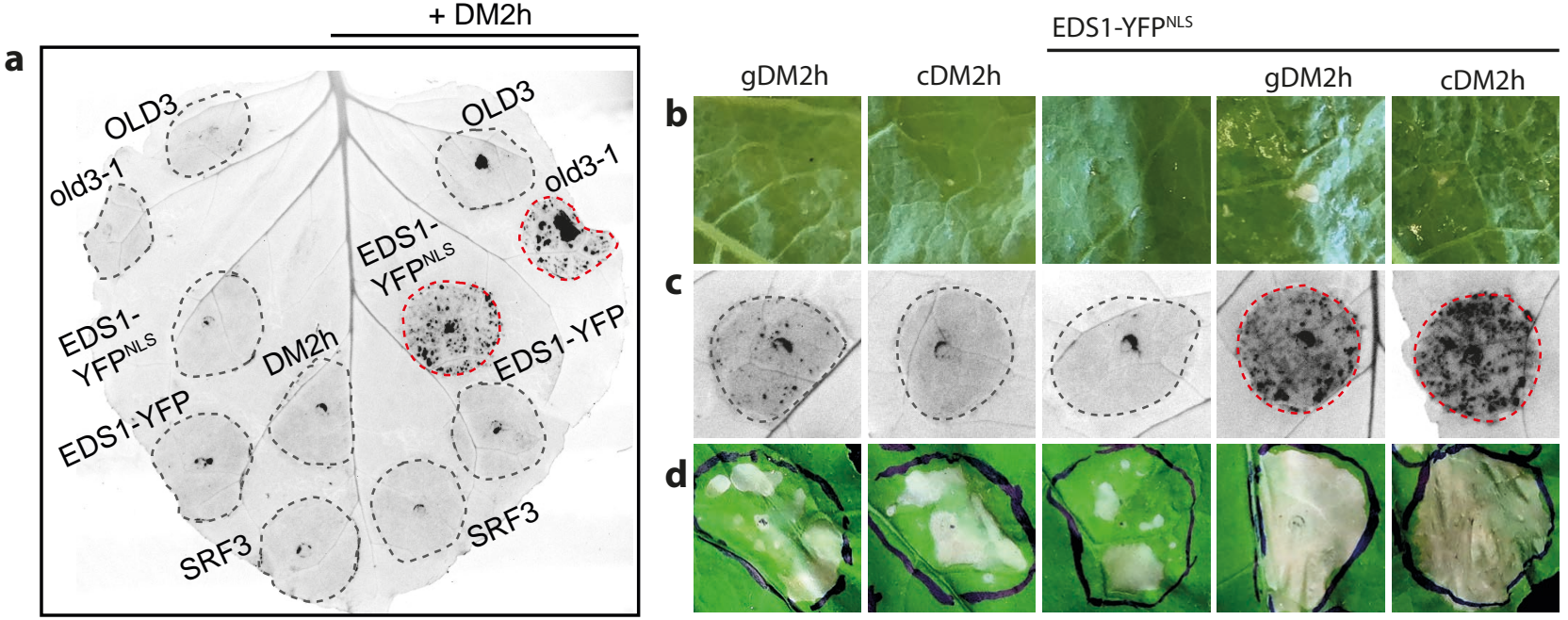

Supplemental Figure 4: A transient assay for reconstitution of DM2h activation in N. benthamiana based on protein co-expression and cell death induction.

a) Induction of HR-like cell death upon co-expression (by Agroinfiltration) of DM2h (35S:gDM2h) with different autoimmunity inducers or variants thereof. Agrobacterium strains for the expression of indicated proteins (under $35 \mathrm{~S}$ promoter control) were infiltrated into $\mathrm{Nb}$ wild-type leaves. The formation of HR-like cell death was photographed 7 dpi on a gel documentation system.

b) - d) as in a), but the DM2h gDNA and a cDNA construct (corresponding to the gene model shown in Figure 1a) were compared for cell death induction, and different methods were used to document plant reactions. b) shows macroscopically visible plant reactions. Tissues from co-expression became glossy at the surface, and small necrotic patches appeared. c) shows cell death reactions as visualized under UV light using a gel documentation system. d) shows macroscopic plant reactions at $5 \mathrm{dpi}$ when plants were incubated for $2 \mathrm{~d}$ in the dark subsequent to infiltration to enhance cell death induction, as described before (Chae et al., 2014; Qi et al., 2018). Similar results were obtained when expressing DM2h from a gDNA or a cDNA construct. cDNA constructs were used for site-directed mutagenesis and all further experiments. 
bioRxiv preprint doi: https://doi.org/10.1101/2020.11.01.363895; this version posted November 2, 2020. The copyright holder for this preprint (which was not certified by peer review) is the author/funder, who has granted bioRxiv a license to display the preprint in perpetuity. It is made available under aCC-BY-ND 4.0 International license.

\section{Supplemental Figure 5 Ordon et al.}

a

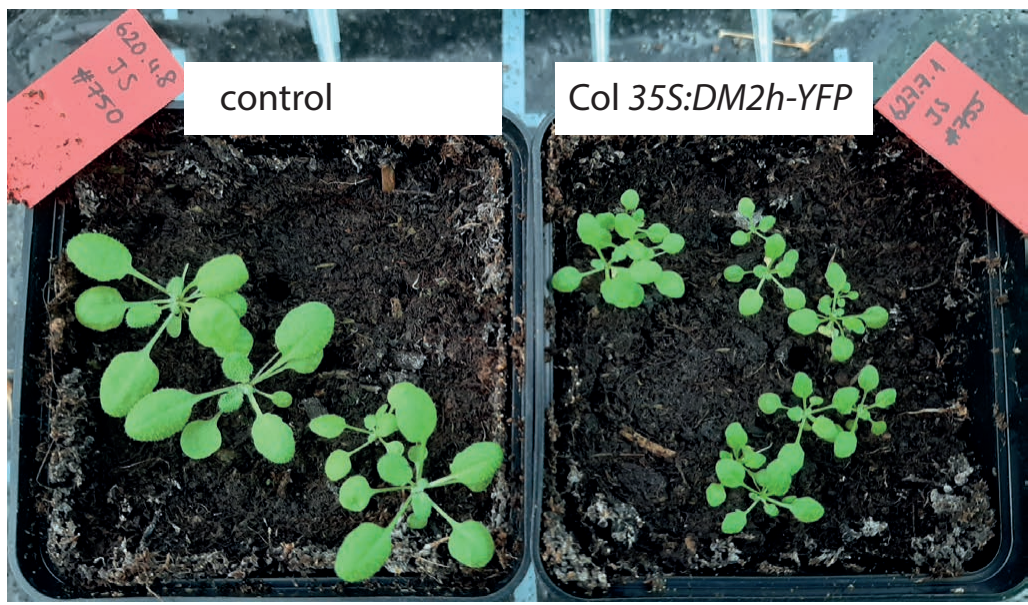

$\mathrm{b}$

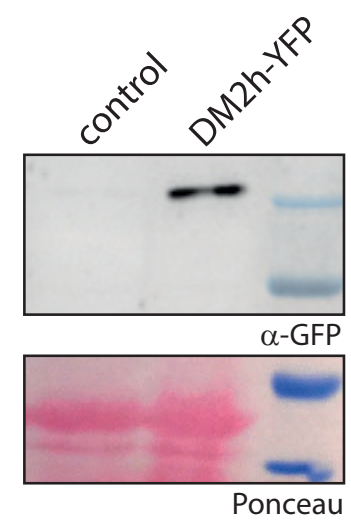

Supplemental Figure 5: Growth phenotype and immunoblot analysis of DM2h-YFP transgenic plants.

a) Homozygous $\mathrm{T}_{3}$ transgenics containing 35S:gDM2h-YFP and a control line were grown side-by-side under short day conditions for four weeks. DM2h-YFP transgenic plants were smaller, and showed some necrotic lesions indicative of autoimmunity on lower leaves, suggesting that the DM2h-YFP fusion protein is at least partially functional.

b) Immunodetection of the DM2h-YFP fusion protein. Tissue samples were taken from the same plants that were used for live cell imaging (Figure $5 \mathrm{~g}$ ). 


\section{Supplemental Figure 6 Ordon et al.}

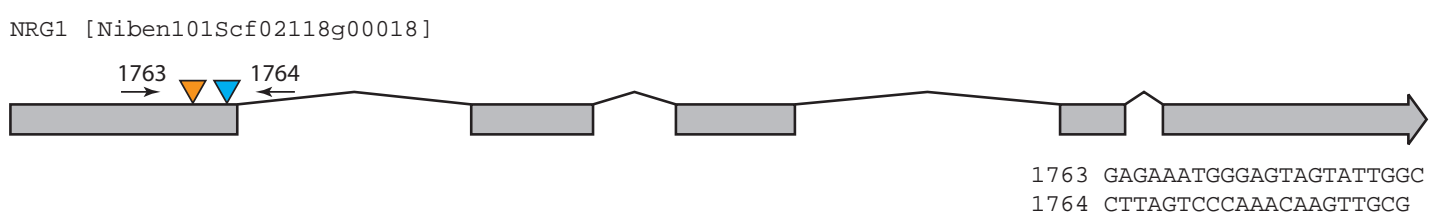

\begin{tabular}{ll} 
NRG1 $1717+1718 \quad$ PAM & $1719+1720 \quad$ PAM \\
\hline
\end{tabular}

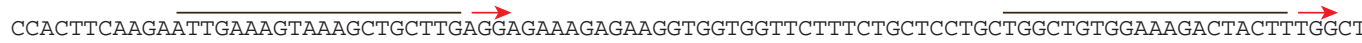

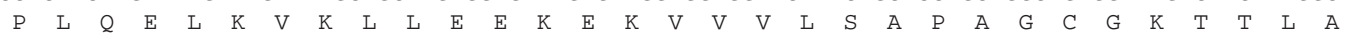

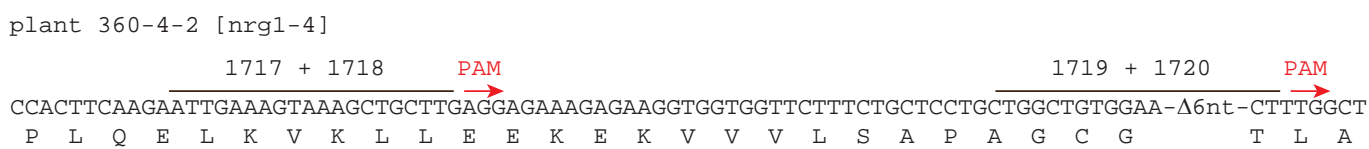

Supplemental Figure 6: Molecular details on Nbnrg1 mutant lines generated in this study.

The NbNRG1 locus was targeted for genome editing using sgRNAs previously reported in Qi et al. (2018). The locus with the relative position of the target sites is show as an overview and at the nucleotide level. Two different homozygous lines, nrg 1-4 and nrg1-5, were isolated from a segregating $T_{1}$ population (plant 360-4). PCR primers used for screening and sequencing of alleles (1763/1764) are indicated. Final lines do not contain the T-DNA anymore. Similar phenotypes were observed with both lines. 


\section{Supplemental Figure 7 Ordon et al.}

a

EDS1-YFPNLS

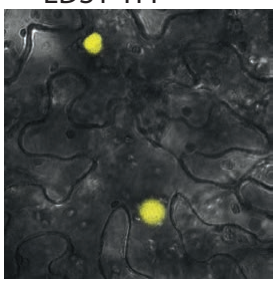

eds1(F419E)-YFPNLS

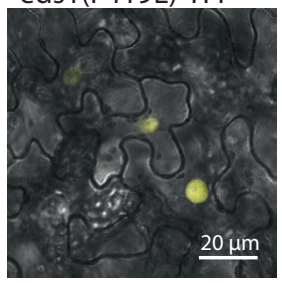

b

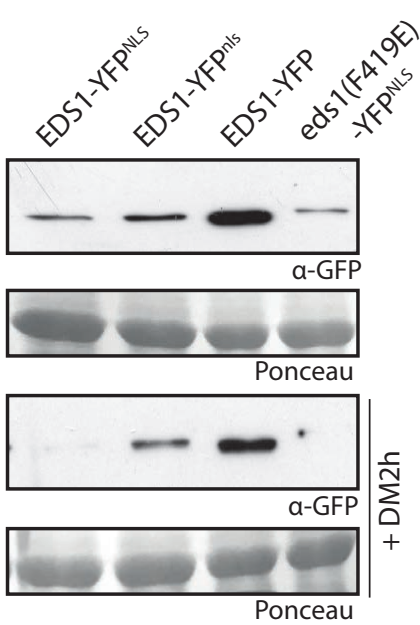

C

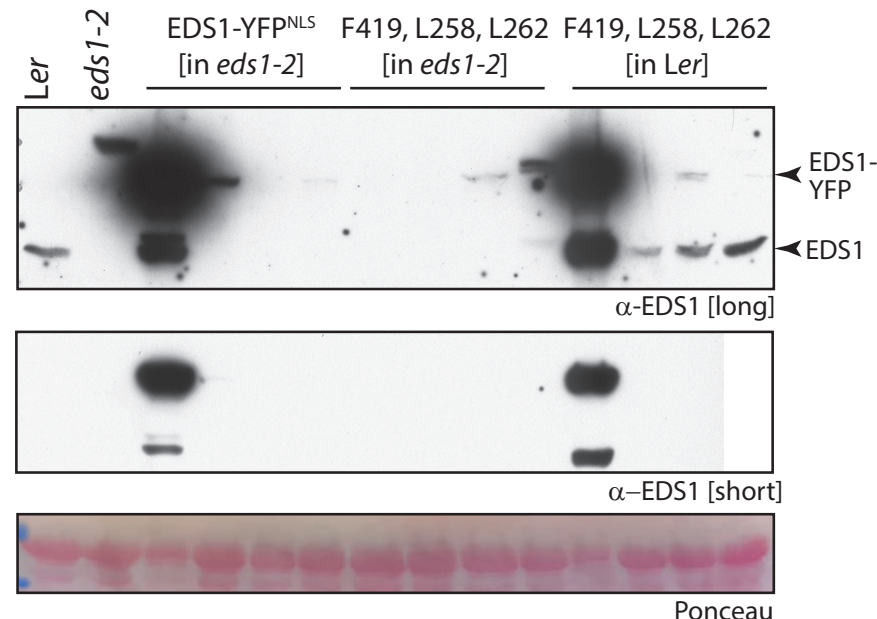

Supplemental Figure 7: Immunodetection and subcellular localization of EDS1-YFPNLS variants differing in immune signaling competency.

a) Localization of EDS1-YFPNLS variants In N. benthamiana (in co-expression with DM2h) as assessed by confocal laser scanning microscopy at $3 \mathrm{dpi}$. An overlay of bright field and YFP imaging (yellow) is shown. Similar localizations were observed when EDS1 variants were expressed without DM2h. Scale bar $=20 \mu \mathrm{m}$.

b) Immunodetection of fusion proteins expressed in Figure 6a and S7a. Tissues were harvested $3 \mathrm{dpi}$, and total protein extracts used for SDS-PAGE and immunodetection.

c) Immunodetection of EDS1-YFPNLS variants in primary Arabidopsis transformants (in support of Figure 6b). Transgenic seeds were selected by FAST seed fluorescence. Plants were grown $7 \mathrm{~d}$ under short day conditions, $20 \mathrm{~d}$ under immune suppressive high temperature conditions and shifted to $16 / 14^{\circ} \mathrm{C}$ for $8 \mathrm{~d}$. Lanes with strong EDS1-YFP signals correspond to autoimmune plants. Remaining plants were selected randomly. Low accumulation of the EDS1-YFPNLS [F419E, L258A, L262A] in the eds1-2 mutant background is most likely due to low EDS1 expression in absence of 
bioRxiv preprint doi: https://doi.org/10.1101/202011.01.363895; this version posted November 2, 2020. The copyright holder for this preprint (which was not certified by peer review) is the author/funder, who has granted bioRxiv a license to display the preprint in perpetuity. It is made available under aCC-BY-ND 4.0 International license.

\section{Supplemental Figure 8 Ordon et al.}

a
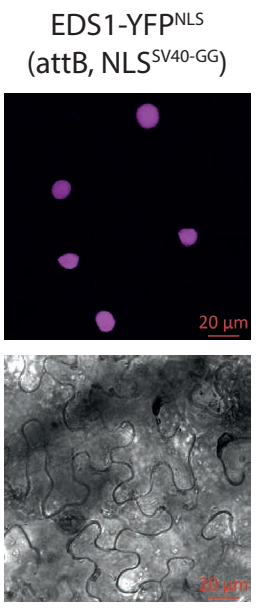

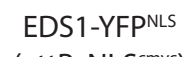

(attB, NLScmyc)
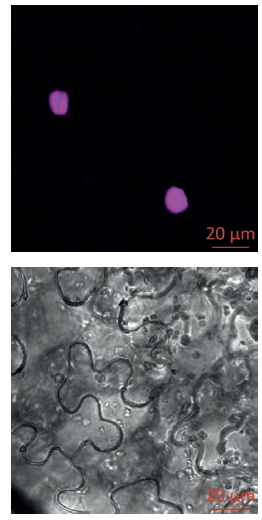
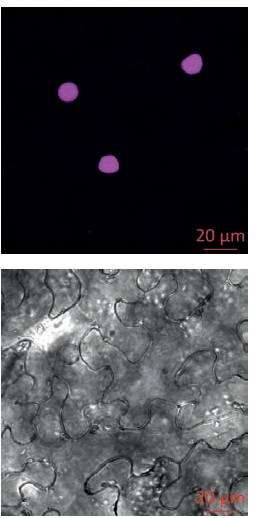

EDS1-YFPNLS

$\left(\mathrm{SA}, \mathrm{NLS} \mathrm{SV}^{\mathrm{S}}\right.$ )
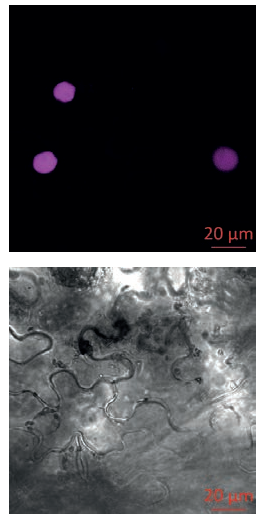

EDS1-YFP NLS

(SA, NLS cmyc)
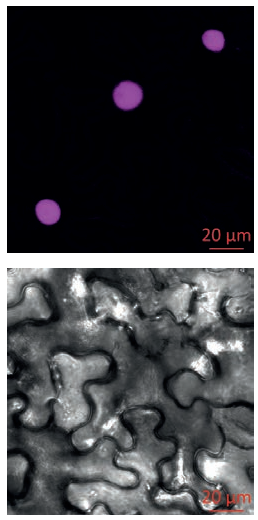

b

EDS1-YFPNLS

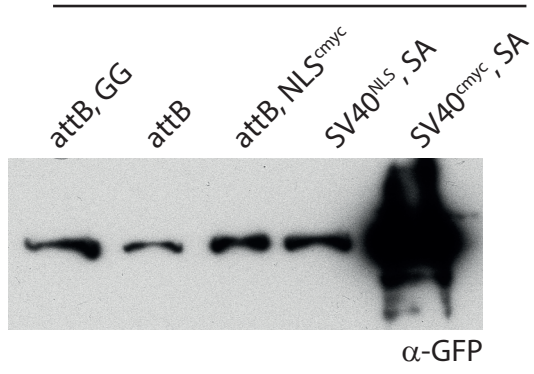

Supplemental Figure 8: Immunodetection and subcellular localization of EDS1-YFPNLS variants differing in NLS and linker sequences.

a) Localization of EDS1-YFPNLS variants (in co-expression with DM2h) as assessed by confocal laser scanning microscopy at 3 dpi. YFP channel (magenta) and bright field images are shown. Similar results were obtained upon co-expression of fusions without DM2h. Scale bar $=20 \mu \mathrm{m}$.

b) Immunodetection of fusion proteins expressed in Figures 7 and S8a. Tissues were harvested 3 dpi from the same 


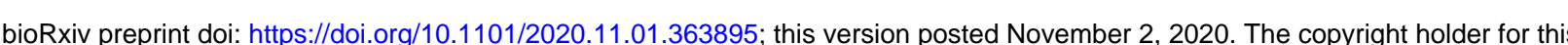
preprint (which was not certified by peer review) is the author/funder, who has granted bioRxiv a license to display the preprint in perpetuity. It is made available under aCC-BY-ND 4.0 International license.

Table S1: Molecular details on identified $d m 2 h / n d e 1$ alleles

\begin{tabular}{|c|c|c|}
\hline mutant allele & mutation & phenotype \\
\hline nde1-1 & $\Delta 16 \mathrm{bp}$ & wild type-like (Stuttmann et al., 2016) \\
\hline nde1-3 & $\Delta d m 2 c-h$ & wild type-like (Stuttmann et al., 2016) \\
\hline nde1-13 & W1129STOP & wild type-like (Stuttmann et al., 2016) \\
\hline nde1-150 & R1069C & wild type-like (Stuttmann et al., 2016) \\
\hline nde1-175 & C945Y & wild type-like (Stuttmann et al., 2016) \\
\hline nde1-201 & $\mathrm{A} 1007 \mathrm{~T}$ & n. d. \\
\hline nde1-203 & L940F & n. d. \\
\hline nde1-8 & L958F & n. d. \\
\hline nde1-18 & P692S & partial rescue (intermediate) \\
\hline nde1-20 & P1015L & n. d. \\
\hline nde1-23 & P803S & wild type-like \\
\hline nde1-24 & G102E & wild type-like \\
\hline nde1-26 & L746F & n. d. \\
\hline nde1-31 & recombination event at $D M 2$ & n. d. \\
\hline nde1-32 & V648M & wild type-like \\
\hline nde1-34 & S506N & partial rescue (intermediate) \\
\hline nde1-40 & S703N & wild type-like \\
\hline nde1-41 & W709STOP & wild type-like \\
\hline nde1-49 & W720STOP & partial rescue (intermediate) \\
\hline nde1-51 & splice site & weak \\
\hline nde1-53 & D964N & wild type-like \\
\hline nde1-59 & A808V & wild type-like \\
\hline nde1-60 & W1133STOP & wild type-like \\
\hline nde1-65 & Q682STOP & wild type-like \\
\hline nde1-75 & C1085Y & wild type-like \\
\hline nde1-114 & S583F & n. d. \\
\hline nde1-145 & E697K & wild type-like \\
\hline nde1-147 & S982N & wild type-like \\
\hline nde1-161 & T1921 & wild type-like \\
\hline nde1-166 & N810I & wild type-like \\
\hline
\end{tabular}

n.d. - not determined 
bioRxiv preprint doi: https://doi.org/10.1101/2020.11.01.363895; this version posted November $2,2020$. The copyright holder for this preprint (which was not certified by peer review) is the author/funder, who has granted bioRxiv a license to display the preprint in perpetuity. It is made available under aCC-BY-ND 4.0 International license.

Table S2: Oligonucleotides used in this study

\begin{tabular}{|c|c|c|}
\hline \#* & Sequence $5^{\prime}->3^{\prime}$ & Purpose \\
\hline 724 & tttggtctcaATTCGAAAGCCAGAGGCAGATAAGAAG & \multirow{7}{*}{$\begin{array}{l}\text { Amplification and sequencing of } \\
\text { DM } 2 \mathrm{~h}\end{array}$} \\
\hline 725 & tttggtctcaAAGCGCAATCAAGCGCATTACAGATGG & \\
\hline 729 & TTTgaagacaaGTgTTCCCGAGCTTCCACGG & \\
\hline 731 & TGAGTACAGTGCACAATTGC & \\
\hline 733 & TGGAGATATGACTAATCTCG & \\
\hline 1155 & ACTAGCCTCGACGGAAATATCG & \\
\hline 1156 & GGGCGATGCAATGGCAAAAC & \\
\hline 972 & TTTgaagacAAaATGGGTTCTGCAATGAGCTTG & \multirow{10}{*}{$\begin{array}{l}\text { Cloning and domestication of } \mathrm{DM} 2 \mathrm{~h} \\
\text { CDNA }\end{array}$} \\
\hline 973 & TTTgaagacAAAcACGTGGTGTTTCCAGATTCG & \\
\hline 729 & TTTgaagacaaGTgTTCCCGAGCTTCCACGG & \\
\hline 1035 & TTTgaagacAAtccaGTTGCGAGAATGTTCTC & \\
\hline 1036 & TTTgaagacAAtggaGGAATGAAGCAGACATG & \\
\hline 974 & TTTgaagacAATGtAGACCTTGTTTCACATCC & \\
\hline 975 & tttgaagacaaTaCACGTATTAGCTCAGAAATC & \\
\hline 976 & TTTgaagacAACCTCAGAATTACTCAAATCCATC & \\
\hline 977 & TTTgaagacaaGAgGACTTGAAAGAGCTTCCC & \\
\hline 978 & TTTgaagacAAaagcCTAACAGTGGTCGCAGCTGG & \\
\hline 661 & ATGTCTTGTCACAGTGCTCG & \multirow{2}{*}{$\begin{array}{c}\text { Genotyping: Presence of the EDS1- } \\
\text { YFP }{ }^{N L S} \text { transgene }\end{array}$} \\
\hline 328 & TGGGTTTTTATGATTAGAGTCC & \\
\hline 735 & TGGCTCCTTCAACGTTGCG & \multirow{2}{*}{$\begin{array}{l}\text { Genotyping: Presence of the } \\
n p: D M 2 h(g D N A) \text { transgene }\end{array}$} \\
\hline 1154 & CAAGAGGACAAACCAGTTGCG & \\
\hline 663 & CGGAATTGATGTTTTGGACC & \multirow{2}{*}{$\begin{array}{l}\text { Genotyping: Col/Ler marker on } \\
\text { chromosome 3, flanking DM2 (left) }\end{array}$} \\
\hline 664 & TACATTCTACAACCATGTAGCC & \\
\hline 657 & CAATGCTCTTCTTTACCAAAAACA & \multirow{2}{*}{$\begin{array}{c}\text { Genotyping: Col/Ler marker on } \\
\text { chromosome 3, flanking DM2 (right) }\end{array}$} \\
\hline 658 & TGTTGGATTTGAAACGTGGA & \\
\hline 1023 & GCAATGCCCAАTTCACTCCT & \multirow{2}{*}{$\begin{array}{c}\text { Genotyping: Presence of } \Delta d m 2-3 \\
\text { deletion }\end{array}$} \\
\hline 1024 & CGTATGGCTATTTTCATCCGC & \\
\hline 1382 & TGCAGCTGAAGATCATGGC & \multirow{2}{*}{$\begin{array}{c}\text { Genotyping: Presence of } \Delta d m 2-11 \\
\text { deletion }\end{array}$} \\
\hline 1383 & GACTAGCGATTGTGTCCATC & \\
\hline 1151 & CCTTTGGACAAAAGCACCCAA & \multirow{2}{*}{$\begin{array}{l}\text { Genotyping: Presence of } D M 2 c / d m 2 c- \\
4\end{array}$} \\
\hline 1152 & CCGATTTTTCCGTCGAGGCTA & \\
\hline 1622 & AAAgaagacAAcgaaccTTCCAGCATATCCATATGAG & \multirow{4}{*}{$\begin{array}{l}\text { Cloning of } G 2 \text { derivatives of } D M 2 h(1- \\
\text { 279) }\end{array}$} \\
\hline 1623 & TTTgaagacAAaATGaGTTCTGCAATGAGCTTG & \\
\hline 1624 & TTTgaagacAAaATGGagTCTGCAATGAGCTTG & \\
\hline 1203 & TTTgaagacAAaATGGcTTCTGCAATGAGCTTG & \\
\hline 1426 & GTTCGAAAAACCATTCTTgCTgCCATCCTCGAATCGTTCA & \multirow{2}{*}{$\begin{array}{l}\text { Introduction of } \mathrm{SH}->\mathrm{AA} \text { mutation into } \\
\qquad \mathrm{DM} 2 h\end{array}$} \\
\hline 1427 & TGAACGATTCGAGGATGgCAgCAAGAATGGTTTTTCGAAC & \\
\hline JG15 & tttgaagacTTaATGGCGtttgaagctctt & \multirow{4}{*}{$\begin{array}{l}\text { Cloning of EDS1-YFPNLS as MoClo Level } \\
\qquad 0 \text { module }\end{array}$} \\
\hline 1182 & TCGGCGCGCCCACCCTTGGTATCTGTTATTTCATC & \\
\hline 1183 & GATGAAATAACAGATACCAAGGGTGGGCGCGCCGA & \\
\hline 1184 & tttgaagacaaaagcTTATCCTCCAACCTTTCTC & \\
\hline 1412 & GTACAAGCCTAAGACGAAGAGAAAGGTTG & \multirow{2}{*}{ Mutagenesis NLS->nls } \\
\hline 1413 & CAACCTTTCTCTTCgTCTTAGGCTTGTAC & \\
\hline JG15 & tttgaagacTTaATGGCGtttgaagctctt & \multirow{2}{*}{ Cloning EDS1-YFP } \\
\hline 968 & tttgaagacAAaagcTCATTTGTACAGCTCGTCCATGC & \\
\hline
\end{tabular}


bioRxiv preprint doi: https://doi.org/10.1101/2020.11.01.363895; this version posted November 2,2020 . The copyright holder for this preprint (which was not certified by peer review) is the author/funder, who has granted bioRxiv a license to display the preprint in perpetuity. It is made available under aCC-BY-ND 4.0 International license.

\begin{tabular}{|c|c|c|}
\hline \#* & Sequence $5^{\prime}->3^{\prime}$ & Purpose \\
\hline 1695 & GAACAATTGGTCAATCATGGTTAT & \multirow{6}{*}{ Cloning of $D M 2 c$ TIR fragment } \\
\hline 1696 & TGTCCGAACGAAACAGATCA & \\
\hline 1697 & ttgaagacatctcaAATGGATTCTTCTTTTTTCCTTGTC & \\
\hline 1698 & ttgaagactaaACATCGTGTTTCCAGTTTCG & \\
\hline 1699 & ttgaagacatTGTtTTCCCGAGCTTCCACGGAGC & \\
\hline 1700 & ttgaagacaactcgCAGTTGCGAGAATGTTCTC & \\
\hline 1701 & ttgaagacatctcaactgGAGGAATGAAGCAGACATG & \multirow{2}{*}{ Cloning of $D M 2 h$ NB-LRR fragment } \\
\hline 1702 & ttgaagacaactcgaagcCTAACAGTGGTCGCAGCTG & \\
\hline 1703 & ACCGCCTGGGATTGCTAAGACAACTATCG & \multirow{2}{*}{$\begin{array}{l}\text { Introduction of G301A mutation into } \\
\qquad M M 2 h\end{array}$} \\
\hline 1704 & CGATAGTTGTCTTAgCAATCCCAGGCGGT & \\
\hline 1705 & CGCCTGGGATTGGTCgGACAACTATCGCCA & \multirow{2}{*}{$\begin{array}{c}\text { Introduction of } \mathrm{K} 302 \mathrm{R} \text { mutation into } \\
\mathrm{DM} 2 \mathrm{~h}\end{array}$} \\
\hline 1706 & TGGCGATAGTTGTCCgACCAATCCCAGGCG & \\
\hline 2024 & CCGCCTGGGATTGCTCgGACAACTATCG & \multirow{2}{*}{$\begin{array}{l}\text { Introduction of GK double mutation } \\
\text { into } D M 2 h\end{array}$} \\
\hline 2025 & CGATAGTTGTCCgAgCAATCCCAGGCGG & \\
\hline JG355 & tttgaagacaattcGTCATTCTCTTCATTTGAAACT & \multirow{2}{*}{$\begin{array}{c}\text { Introduction of F419E mutation into } \\
\text { EDS1-YFP }\end{array}$} \\
\hline JG356 & tttgaagacaacgaAAAAGCAAACGTCAAGAGAG & \\
\hline JG15 & tttgaagacTTaATGGCGtttgaagctctt & \multirow{2}{*}{ Cloning of EDS1-YFPNLS (GW,-GG) } \\
\hline JG81 & tttgaagacaaagettaAACCTTTCTCTTCTTCTTAGG & \\
\hline JG15 & tttgaagacTTaATGGCGtttgaagctctt & \multirow[b]{2}{*}{ Cloning of EDS1-YFPNLS (GW,cmyc) } \\
\hline 2027 & $\begin{array}{l}\text { ttgaagacataagCTAGTCGAGTTTAACTCTTTTGGCAGCAG } \\
\text { GtgcagatTTGTACAGCTCGTCCATGC }\end{array}$ & \\
\hline 969 & tttgaagacaattcggctGTGAGCAAGGGCGAGGAGC & \multirow{2}{*}{ Cloning of YFP with c-myc NLS } \\
\hline 1184 & tttgaagacaaaagcTTATCCTCCAACСTTTCTC & \\
\hline JG15 & tttgaagacTTaATGGCGtttgaagctctt & \multirow{2}{*}{$\begin{array}{c}\text { Cloning of EDS1 (Arabidopsis) as } \\
\text { CDS1ns module }\end{array}$} \\
\hline 2026 & ttgaagacatcgaagcGGTATCTGTTATTTCATCC & \\
\hline 969 & tttgaagacaattcggctGTGAGCAAGGGCGAGGAGC & \multirow{2}{*}{$\begin{array}{c}\text { Cloning of YFP (mVenus) with c-myc } \\
\text { NLS as CT }\end{array}$} \\
\hline 2027 & $\begin{array}{l}\text { ttgaagacataagCTAGTCGAGTTTAACTCTTTTGGCAGCAG } \\
\text { GtgcagatTTGTACAGCTCGTCCATGC }\end{array}$ & \\
\hline 967 & tttgaagacaaaATGGTGAGCAAGGGCGAGG & \multirow{2}{*}{$\begin{array}{l}\text { Cloning of YFP } \\
\text { residues) (SV40, with Gly } \\
\text { CDS1 module }\end{array}$} \\
\hline 1184 & tttgaagacaaaagcTTAтCСТCСАAССТTTCTC & \\
\hline 967 & tttgaagacaaaATGGTGAGCAAGGGCGAGG & \multirow{2}{*}{$\begin{array}{c}\text { Cloning of YFP } \\
\text { module }\end{array}$} \\
\hline JG81 & tttgaagacaaagettaAACСTTTCTCTTCTTCTTAGG & \\
\hline 836 & CTTTGAGTGAGCTGATACCG & \multirow{2}{*}{ sequencing Level 0 modules } \\
\hline 837 & GGGTTCCGCGCACATTTC & \\
\hline JG15 & tttgaagacTTaATGGCGtttgaagctctt & \multirow{4}{*}{$\begin{array}{c}\text { Cloning of EDS1-YFPNLS (domesticated, } \\
\text { with GW linker), via SOE-PCR and } \\
\text { GoldenGate cloning }\end{array}$} \\
\hline 1182 & TCGGCGCGCCCACCCTTGGTATCTGTTATTTCATC & \\
\hline 1183 & GATGAAATAACAGATACCAAGGGTGGGCGCGCCGA & \\
\hline 1184 & tttgaagacaaaagcTTATCCTCCAACСTTTCTC & \\
\hline 453 & ccctttctagtttcGCtgagctaagtcctt & \multirow{2}{*}{$\begin{array}{c}\text { Introduction of L262A mutation in } \\
\text { AtEDS1 }\end{array}$} \\
\hline 454 & aaggacttagctcaGCgaaactagaaaggg & \\
\hline 1940 & CGATTTTAGAaACCgCTTCTAGTTTCGCTG & \multirow{2}{*}{$\begin{array}{l}\text { Introduction of L258A mutation in } \\
\text { AtEDS1 }\end{array}$} \\
\hline 1941 & CAGCGAAACTAGAAgCGGTtTCTAAAATCG & \\
\hline
\end{tabular}


bioRxiv preprint doi: https://doi.org/10.1101/2020.11.01.363895; this version posted November 2, 2020. The copyright holder for this preprint (which was not certified by peer review) is the author/funder, who has granted bioRxiv a license to display the preprint in perpetuity. It is made available under aCC-BY-ND 4.0 International license.

\begin{tabular}{|c|c|c|}
\hline \#* & Sequence $5^{\prime}->3^{\prime}$ & Purpose \\
\hline 1676 & ttggtctcaacatgcttGTCCGCAAAAATCACCAG & \multirow{8}{*}{$\begin{array}{c}\text { Cloning of t35S::tNbAct::Rb7MAR } \\
\text { "triple terminator" (Diamos and } \\
\text { Mason, 2018). PCR products were } \\
\text { cloned into Level -1 vector pAGM1311 } \\
\text { and combined in Level } 0 \text { vector } \\
\text { pICH41276 }\end{array}$} \\
\hline 1677 & ttggtctcaacaaGGTCACTGGATTTTGGTTTTAGG & \\
\hline 1678 & TTGGTCTCAACATgaccatacagcattcccagaaagag & \\
\hline 1679 & ttggtctcaacaaCagaccaaaatgaactgacaagc & \\
\hline 1680 & ttggtctcaacattctGatttttttggtatccaaataag & \\
\hline 1681 & ttggtctcaacaaTcGatgctagcttgtttacacctc & \\
\hline 1682 & TTggtctcaacattcgattaaaatcccaattatatttgg & \\
\hline 1683 & ttggtctcaacaaAGCGcactattttcagaagaagttcc & \\
\hline qPR1-F & TTCTTCCCTCGAAAGCTCAA & \multirow{2}{*}{ qPCR, PR1 } \\
\hline qPR1-R & AAGGCCCACCAGAGTGTATG & \\
\hline 582 & AGATCCAGGACAAGGAGGTATTC & \multirow{2}{*}{ qPCR, UBQ10 } \\
\hline 583 & CGCAGGACCAAGTGAAGAGTAG & \\
\hline
\end{tabular}


bioRxiv preprint doi: https://doi.org/10.1101/2020.11.01.363895; this version posted November $2,2020$. The copyright holder for this preprint (which was not certified by peer review) is the author/funder, who has granted bioRxiv a license to display the preprint in perpetuity. It is made available under aCC-BY-ND 4.0 International license.

Table S3: Plasmids used in this study

Previously reported plasmids:

\begin{tabular}{|c|c|c|}
\hline name & Description & Reference \\
\hline pUC57-Bsal & pUC57 derivative without Bsal site in bla & \multirow{2}{*}{ (Ordon et al., 2017) } \\
\hline pVM_BGW & T-DNA vector, pVS1 origin of replication & \\
\hline pJOG899 & $\mathrm{DM}_{2} \mathrm{~h}_{(1-279)}$ without STOP in pAGM1287 & \multirow{5}{*}{$\begin{array}{l}\text { (Gantner et al., 2018; } \\
\text { Gantner et al., 2019) }\end{array}$} \\
\hline pJOG604 & FAST as 1-1r & \\
\hline pJOG640 & [Pro+5Uf] p35S-long & \\
\hline pJOG176 & mEGFP [CT] & \\
\hline pJOG25 & pEDS1 [Pro+5U] & \\
\hline pAGM9121 & \multirow{6}{*}{ Level 0 vectors Modular Cloning system } & \multirow{16}{*}{ (Engler et al., 2014) } \\
\hline $\mathrm{plCH} 41421$ & & \\
\hline $\mathrm{plCH} 41308$ & & \\
\hline pAGM41276 & & \\
\hline $\mathrm{pICH} 41295$ & & \\
\hline pAGM1287 & & \\
\hline plCH47732 (1-1f) & \multirow{3}{*}{ Level 1 vectors Modular Cloning system } & \\
\hline pICH47742 (1-2f) & & \\
\hline pICH47751 (1-3f) & & \\
\hline pICH51266 & 35S Promoter [Pro+5U] & \\
\hline plCH51277 & 35S Promoter [Pro+5U] & \\
\hline $\mathrm{plCH} 41414$ & $35 \mathrm{~S}$ terminator [3U+ter] & \\
\hline plCH50881 & end linker & \\
\hline $\mathrm{plCH} 41744$ & end linker & \\
\hline pICSL30008 & $6 x \mathrm{HA}[\mathrm{NT}]$ & \\
\hline pAGM1311 & Level -1 universal acceptor & \\
\hline pXCSG-YFP & $\begin{array}{l}\text { pAM-PAT-based GW destination vector; } \\
\text { 35S:GW-YFP_t35S }\end{array}$ & $\begin{array}{l}\text { pAM-PAT -> GenBank } \\
\text { AY436765.1 }\end{array}$ \\
\hline
\end{tabular}

Level 0 modules (cloned as described in Engler at al., 2014, or created by site-directed mutagenesis (SDM; dx.doi.org/10.17504/protocols.io.behgjb3w)):

\begin{tabular}{|c|c|c|c|}
\hline Name & Recipient & Description & $\begin{array}{c}\text { Oligo- } \\
\text { nucleotides* }\end{array}$ \\
\hline pJOG900 & pAGM1287 & $\mathrm{DM} 2 \mathrm{~h}_{(1-279)}[\mathrm{G} 2 \mathrm{~S}]$ without STOP & JS1623/1622 \\
\hline pJOG901 & pAGM1287 & $\mathrm{DM} 2 \mathrm{~h}_{(1-279)}[\mathrm{G} 2 \mathrm{E}]$ without STOP & JS1624/1622 \\
\hline pJOG908 & pAGM1287 & $\mathrm{DM}_{2} \mathrm{~h}_{(1-279)}[\mathrm{G} 2 \mathrm{~A}]$ without STOP & JS1203/1622 \\
\hline pJOG941 & pAGM1287 & $\mathrm{DM}_{2 \mathrm{~h}_{(1-279)}[\mathrm{SH}-\mathrm{AA}] \text { without STOP }}$ & SDM JS1426/27 \\
\hline pJOG273 & $\mathrm{plCH} 41308$ & cDNA of DM2h as CDS1 (domesticated) & see methods \\
\hline pJOG486 & plCH41308 & EDS1-YFPNLS (domesticated, with GW linker) & $\begin{array}{c}\text { JG15/JS1182, } \\
\text { JS1183/1184 }\end{array}$ \\
\hline pJOG813 & plCH41308 & EDS1-YFPNLS [F419E] & $\begin{array}{c}\text { JG355/56, Dpnl- } \\
\text { Bpil+ligase }\end{array}$ \\
\hline pJOG1165 & plCH41308 & EDS1-YFP $^{N L S}[F 419 E, L 262 A]$ & SDM JS453/454 \\
\hline pJOG1166 & plCH41308 & EDS1-YFP $^{\text {NLS }}[\mathrm{F} 419 \mathrm{E}, \mathrm{L} 258 \mathrm{~A}, \mathrm{~L} 262 \mathrm{~A}]$ & JS1940/41 \\
\hline pJOG1008 & plCH41276 & $\begin{array}{l}\text { t35S::tNbAct::Rb7MAR terminator (Diamos and Mason, } \\
\text { 2018) as MoClo Level } 0 \text { module } \\
\text { [intermediate cloning of PCR products into Level -1 } \\
\text { vector pAGM1311) }\end{array}$ & $\begin{array}{l}\text { JS1676/1677, } \\
\text { JS1678/1679, } \\
\text { JS1680/1681, } \\
\text { JS1682/1683 }\end{array}$ \\
\hline pJOG747 & plCH41308 & EDS1-YFP (including GW linker) as CDS1 module & JG15, JS968 \\
\hline
\end{tabular}




\begin{tabular}{|c|c|c|c|}
\hline Name & Recipient & Description & $\begin{array}{c}\text { Oligo- } \\
\text { nucleotides* }\end{array}$ \\
\hline pJOG993 & pAGM9121 & DM2c_TIR & $\begin{array}{l}\text { JS1697/98, } \\
\text { JS1699/1700 on } \\
\text { an amplicon } \\
\text { generated with } \\
\text { JS1695/96 on } \\
\text { gDNA }\end{array}$ \\
\hline pJOG994 & pAGM9121 & DM2h_NB-LRR & JS1701/1702 \\
\hline pJOG996 & $\mathrm{plCH} 41308$ & $\mathrm{DM} 2 \mathrm{~h}[\mathrm{G} 301 \mathrm{~A}]$ as CDS1 & SDM 1703/04 \\
\hline pJOG1011 & plCH41308 & $\mathrm{DM} 2 \mathrm{~h}[\mathrm{~K} 302 \mathrm{R}]$ as CDS1 & SDM1705/06 \\
\hline pJOG1213 & $\mathrm{plCH} 41308$ & $\mathrm{DM} 2 \mathrm{~h}[\mathrm{GK}-\mathrm{AR}]$ as CDS1 & SDM JS2024/25 \\
\hline pJOG1312 & $\mathrm{plCH} 41308$ & EDS1-YFP NLS $(G W,-G G)$ & JG15/JG81 \\
\hline pJOG1337 & $\mathrm{plCH} 41308$ & EDS1-YFPNLS (GW,cmyc) & JG15/JS2027 \\
\hline pJOG1329 & pAGM1301 & YFPNLS as CT (without GG) & JS969/1184 \\
\hline pJOG1212 & pAGM1287 & EDS1 as CDS1ns module & JG15/JS2026 \\
\hline pJOG1235 & pAGM1301 & YFP with c-myc NLS as CT & JS969/2027 \\
\hline pJOG822 & $\mathrm{plCH} 41308$ & 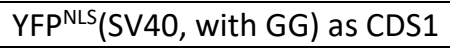 & JS967/1184 \\
\hline pJOG1311 & plCH41308 & YFP $^{N L S}$ (SV40) as CDS1 & JS967/JG81 \\
\hline
\end{tabular}

* sequences of oligonucleotides are provided in Table S2.

Level 1 modules (assembled as described in Engler et al., 2014):

\begin{tabular}{|c|c|c|c|}
\hline Name & Recipient & Inserts & Description \\
\hline pJOG999 & $\mathrm{plCH} 47742$ & $\begin{array}{l}\text { pICH51277, pICH41414, pJOG176, } \\
\text { pJOG899 }\end{array}$ & 35S:DM2h $\mathrm{h}_{(1-279)-G F P}$ \\
\hline pJOG1000 & plCH47742 & $\begin{array}{l}\text { pICH51277, pICH41414, pJOG176, } \\
\text { pJOG900 }\end{array}$ & $35 S: D M 2 h_{(1-279)}[G 2 S]-G F P$ \\
\hline pJOG1001 & plCH47742 & $\begin{array}{l}\text { pICH51277, pICH41414, pJOG176, } \\
\text { pJOG901 }\end{array}$ & $35 S: D M 2 h_{(1-279)}[G 2 E]-G F P$ \\
\hline pJOG1076 & $\mathrm{plCH} 47742$ & $\begin{array}{l}\text { pICH51277, pICH41414, pJOG176, } \\
\text { pJOG908 }\end{array}$ & $35 S: D M 2 h_{(1-279)}[G 2 A]-G F P$ \\
\hline pJOG1077 & plCH47742 & $\begin{array}{l}\text { pICH51277, pICH41414, pJOG176, } \\
\text { pJOG941 }\end{array}$ & $35 S: D M 2 h_{(1-279)}[S H-A A]-G F P$ \\
\hline pJOG274 & plCH47742 & pICH41414, pJOG273, pICH51277 & 35S:DM2h (cDNA) \\
\hline pJOG546 & plCH47751 & pJOG486, pICH41414, pICH51277 & 35S:EDS1-YFPNLS \\
\hline pJOG750 & plCH47751 & pJOG747, plCH41414, plCH51277 & 35S:EDS1-YFP \\
\hline pJOG995 & plCH47742 & $\begin{array}{l}\text { pICH51266, pICH41414, pJOG993, } \\
\text { pJOG994 }\end{array}$ & 35S:DM2c(TIR)-DM2h(NB-LRR) \\
\hline pJOG1009 & plCH47742 & plCH41414, pICH51277, pJOG996 & 35S:DM2h[G301A] \\
\hline pJOG1194 & plCH47742 & pICH41414, pICH51277, pJOG1011 & 35S:DM2h[K302R] \\
\hline pJOG1256 & $\mathrm{plCH} 47742$ & pICH41414, pICH51277, pJOG1213 & 35S:DM2h[GK->AR] \\
\hline pJOG857 & $\mathrm{plCH} 47742$ & $\begin{array}{l}\text { pJOG273, pICH41414, pICSL30008, } \\
\text { pJOG640 }\end{array}$ & 35S:6xHA-DM2h \\
\hline pJOG1010 & plCH47742 & $\begin{array}{c}\text { pICH41414, pJOG996, pICSL30008, } \\
\text { pJOG640 }\end{array}$ & 35S:6xHA-DM2h[G301A] \\
\hline pJOG1195 & plCH47742 & $\begin{array}{l}\text { pICH41414, pJOG1011, pICSL30008, } \\
\text { pJOG640 }\end{array}$ & 35S:6xHA-DM2h[K302R] \\
\hline pJOG1257 & plCH47742 & $\begin{array}{c}\text { pICH41414, pJOG1213, pICSL30008, } \\
\text { pJOG640 }\end{array}$ & 35S:6xHA-DM2h[GK-AR] \\
\hline pJOG746 & plCH47751 & n/a; SDM on pJOG546, oligos 1412/ 1413 & 35S:EDS1-YFP ${ }^{\text {nls }}$ \\
\hline pJOG814 & plCH47751 & pJOG813, pICH41414, pICH51277 & 35S:eds1(F419E)-YFP NLS \\
\hline pJOG1167 & plCH47742 & pJOG25, pJOG486, pJOG1008 & pEDS1:EDS1-YFP ${ }^{N L S}$ \\
\hline
\end{tabular}




\begin{tabular}{|c|c|c|c|}
\hline Name & Recipient & Inserts & Description \\
\hline pJOG1168 & plCH47742 & pJOG25, pJOG1166, pJOG1008 & pEDS1:EDS1-YFP ${ }^{N L S}(F 419, L 258, L 262)$ \\
\hline pJOG1314 & plCH47751 & pICH51277, pICH41414, pJOG1312 & p35S:EDS1-YFPNLS $(G W,-G G)$ \\
\hline pJOG1338 & plCH47751 & pICH51277, plCH41414, pJOG1337 & p35S:EDS1-YFP ${ }^{N L S}$ (GW,cmyc) \\
\hline pJOG1330 & $\mathrm{plCH} 47751$ & $\begin{array}{l}\text { pICH51277, pICH41414, pJOG1329, } \\
\text { pJOG1212 }\end{array}$ & p35S:EDS1-YFPNLS (SV40,SA) \\
\hline pJOG1237 & $\mathrm{plCH} 47742$ & $\begin{array}{l}\text { pICH51266, pJOG1212, pJOG1235, } \\
\text { pJOG1008 }\end{array}$ & p35S:EDS1-YFP NLS (cmyc,SA) \\
\hline pJOG825 & plCH47751 & pJOG822, pICH41414, pICH51277 & p35S:YFPNLS $(+G G)$ \\
\hline pJOG1313 & $\mathrm{plCH} 47751$ & pICH51277, pICH41414, pJOG1311 & p35S:YFPNLS $(-G G)$ \\
\hline pJOG1350 & pICH47742 & pJOG1008, pJOG25, pJOG486 & pEDS1:AtEDS1-YFPNLS (GW, SV40) \\
\hline pJOG1351 & $\mathrm{plCH} 47742$ & pJOG1008, pJOG25, pJOG1337 & pEDS1:AtEDS1-YFP ${ }^{N L S}$ (GW, cmyc) \\
\hline pJOG1352 & plCH47742 & $\begin{array}{c}\text { pJOG1008, pJOG25, pJOG1212, } \\
\text { pJOG1329 }\end{array}$ & pEDS1:AtEDS1-YFP ${ }^{N L S}$ (SA, SV40) \\
\hline pJOG1353 & $\mathrm{plCH} 47742$ & $\begin{array}{c}\text { pJOG1008, pJOG25, pJOG1212, } \\
\text { pJOG1235 }\end{array}$ & pEDS1:AtEDS1-YFP NLS (SA, cmyc) \\
\hline
\end{tabular}

Level 2 vectors (plant transformation vectors; assembled as described in Engler et al., 2014):

\begin{tabular}{|c|c|c|c|}
\hline Name & Recipient & Inserts & Description \\
\hline pJOG1169 & pJOG1051 & pJOG604, pJOG1167, pICH50881 & FAST-pEDS1:EDS1-YFPNLS \\
\hline pJOG1170 & pJOG1051 & pJOG604, pJOG1168, pICH50881 & FAST-pEDS1:EDS1-YFP ${ }^{N L S}(F 419, L 258, L 262)$ \\
\hline pJOG1354 & pJOG1051 & pJOG604, pICH41744, pJOG1350 & FAST-pEDS1:EDS1-YFP ${ }^{N L S}(S V 40)[G W]$ \\
\hline pJOG1355 & pJOG1051 & pJOG604, pICH41744, pJOG1351 & FAST-pEDS1:EDS1-YFP ${ }^{N L S}$ (cmyc) [GW] \\
\hline pJOG1356 & pJOG1051 & pJOG604, pICH41744, pJOG1352 & FAST-pEDS1:EDS1-YFPNLS(SV40) [SA] \\
\hline pJOG1357 & pJOG1051 & pJOG604, pICH41744, pJOG1353 & FAST-pEDS1:EDS1-YFP NLS (cmyc) [SA] \\
\hline
\end{tabular}

\section{Other plasmids}

\begin{tabular}{|c|c|}
\hline Name & Description \\
\hline pJOG1051 & Level 2 recipient prepared from pVM-Bpil; contains ccdB (excised during cloning) \\
\hline pCW5 & 35S:DM2h (gDNA) \\
\hline $\begin{array}{c}\text { pAM-PAT } \\
\text { GW OLD3 }\end{array}$ & $35 S: O L D 3 ;$ OLD3 cDNA recombined into pAM-PAT GW by LR reaction \\
\hline $\begin{array}{c}\text { pAM-PAT } \\
\text { GW old3-1 }\end{array}$ & 35S:old3-1; old3-1 cDNA recombined into pAM-PAT GW by LR recombination. \\
\hline pJOG802 & SRF3(Kondara) in pJOG130 (Gateway entry) \\
\hline pJOG826 & SRF3 in pAM-PAT GW, created by LR reaction \\
\hline $\begin{array}{c}\text { pXCSG-YFP } \\
\text { DM2h }\end{array}$ & gDM2h (noSTOP) in pXCSG-YFP, created by LR reaction \\
\hline
\end{tabular}


bioRxiv preprint doi: https://doi org/10.1101/202011.01.363895; this version posted November 2,2020 . The copyright holder for this preprint (which was not certified by peer review) is the author/funder, who has granted bioRxiv a license to display the preprint in perpetuity. It is made available under aCC-BY-ND 4.0 International license.

\section{References}

Diamos, A.G., and Mason, H.S. (2018). Chimeric 3' flanking regions strongly enhance gene expression in plants. Plant Biotechnol J.

Engler, C., Youles, M., Gruetzner, R., Ehnert, T.M., Werner, S., Jones, J.D., Patron, N.J., and Marillonnet, S. (2014). A Golden Gate Modular Cloning Toolbox for Plants. ACS synthetic biology.

Gantner, J., Ordon, J., Kretschmer, C., Guerois, R., and Stuttmann, J. (2019). An EDS1-SAG101 Complex Is Essential for TNL-Mediated Immunity in Nicotiana benthamiana. The Plant cell 31, 2456-2474.

Gantner, J., Ordon, J., Ilse, T., Kretschmer, C., Gruetzner, R., Lofke, C., Dagdas, Y., Burstenbinder, K., Marillonnet, S., and Stuttmann, J. (2018). Peripheral infrastructure vectors and an extended set of plant parts for the Modular Cloning system. PLoS ONE 13, e0197185.

Ordon, J., Gantner, J., Kemna, J., Schwalgun, L., Reschke, M., Streubel, J., Boch, J., and Stuttmann, J. (2017). Generation of chromosomal deletions in dicotyledonous plants employing a userfriendly genome editing toolkit. Plant J 89, 155-168. 